See discussions, stats, and author profiles for this publication at: https://www.researchgate.net/publication/323655577

Pengembangan Modul Mata Kuliah Pengembangan Kepribadian (MPK) Bahasa Indonesia Fakultas Pertanian Universitas Muhammadiyah Palembang

Thesis · May 2014

CITATIONS

0

1 author:

A. Helaluddin Helaluddin

UIN SULTAN MAULANA HASANUDDIN BANTEN

47 PUBLICATIONS 14 CITATIONS

SEE PROFILE

Some of the authors of this publication are also working on these related projects:

Language \& Literature Teaching View project

Buletin Editor View project

READS

2,630 


\title{
Pengembangan Modul \\ Mata Kuliah Pengembangan Kepribadian (MPK)Bahasa Indonesia Fakultas Pertanian Universitas Muhammadiyah Palembang
}

\author{
Oleh: Helaluddin
}

\section{PENDAHULUAN}

\section{A. Latar Belakang}

Pesatnya perkembangan teknologi dan informasi menuntut para akademisi di perguruan tinggi untuk memiliki kemahiran berbahasa Indonesia yang baik dan benar. Hal ini sangat diperlukan dalam memajukan dan menunjang segala aktivitas akademisnya. Dalam mewujudkan kemahiran berbahasa Indonesia tersebut, matakuliah bahasa Indonesia perlu diberikan kepada mahasiswa.

Matakuliah bahasa Indonesia merupakan matakuliah wajib diberikan di semua strata dan jalur pendidikan. Matakuliah ini masuk dalam kelompok Matakuliah Pengembangan Kepribadian (MPK) bersama-sama dengan matakuliah pendidikan agama, pendidikan bahasa Inggris, dan pendidikan kewarganegaraan. Hal ini sesuai dengan surat keputusan Direktur Jenderal Pendidikan Tinggi Departemen Pendidikan Nasional Republik Indonesia nomor 43/DIKTI/Kep/2006 pasal 6 ayat 2 tentang Rambu-Rambu Pelaksanaan Kelompok Matakuliah Pengembangan Kepribadian di Perguruan Tinggi.

Kebijakan tentang bahasa Indonesia sebagai salah satu matakuliah pengembangan kepribadian di perguruan tinggi bertujuan untuk mewujudkan bahasa Indonesia sebagai bahasa profesi dan keilmuan dinyatakan dalam Surat Keputusan Menteri Pendidikan Nasional Republik Indonesia No. 232/U/2000 tentang Penyusunan Kurikulum Pendidikan Tinggi dan Kurikulum Inti Pendidikan Tinggi serta Penilaian Hasil Belajar Mahasiswa. Melalui surat keputusan ini, 
pemerintah memberi kebebasan kepada semua lembaga pendidikan tinggi untuk mengembangkan silabusnya masing-masing. Pemerintah hanya memberi koridor dan rambu-rambu pedomannya tanpa turut campur terlalu mendalam. Keleluasaan ini diharapkan dapat dijadikan landasan bagi pengelola perguruan tinggi untuk menyusun dan mendesain silabusnya sesuai dengan kebutuhan perguruan tinggi masing-masing.

MPK adalah matakuliah di perguruan tinggi yang menjadi sumber nilai dan pedoman penyelenggaraan program studi dalam mengantarkan mahasiswa mengembangkan kepribadiannya. Kelompok matakuliah ini terdiri atas matakuliah yang relevan dengan tujuan memperluas wawasan, pendalaman intensitas pemahaman dan penghayatan pada MPK inti. Salah satu matakuliah dalam kelompok MPK di perguruan tinggi adalah MPK bahasa Indonesia. MPK bahasa Indonesia ini memiliki tujuan untuk mencapai kemahiran mahasiswa dalam menggunakan bahasa Indonesia untuk menguasai, menerapkan, dan mengembangkan ilmu pengetahuan, teknologi, dan seni dengan rasa tanggung jawab sebagai warga negara Indonesia yang berkepribadian.

Pelaksanaan pembelajaran MPK bahasa Indonesia di perguruan tinggi sampai saat ini masih mengalami banyak kendala. Kendala-kendala tersebut disebabkan oleh berbagai faktor, di antaranya (1) adanya anggapan negatif mahasiswa terhadap bahasa Indonesia, (2) sistem dan model pembelajaran bahasa Indonesia yang belum ideal, dan (3) minimnya bahan ajar yang sesuai dengan kebutuhan mahasiswa (Rahayu, 2007:9).

Lebih lanjut Rahayu (2007:10-11) menjabarkan beberapa anggapan negatif terhadap bahasa Indonesia yang menyebabkan kurangnya penguasaan bahasa Indonesia di perguruan tinggi, antara lain: (1) menganggap bahasa Indonesia ada secara alamiah; (2) menganggap bahasa Indonesia itu mudah; (3) menganggap bahasa Indonesia lebih rendah dari bahasa asing.

Senada dengan pendapat di atas, Dr. James Sneddon (dikutip Gur), Associate professor dari Griffith University menyayangkan bentuk-bentuk promosi yang menekankan bahwa bahasa Indonesia adalah bahasa yang mudah. Menurutnya, bahasa Indonesia sama susahnya dengan bahasa lain yang harus 
dipelajari dengan serius seperti kita mempelajari bahasa Inggris, Perancis, dan lainlain(http://www.bahasakita.com/articles/bahasa-indonesia-siapa-yang-seharusnyabelajar/).

Di sisi lain, sistem dan model pembelajaran di perguruan tinggi selama ini belum mencerminkan fungsi dan peran bahasa Indonesia yang sesungguhnya. Hal itu ditegaskan Dendy Sugono di harian Suara Pembaharuan pada tanggal 28 Mei 2009 yang menyatakan bahwa pembelajaran matakuliah bahasa Indonesia selama ini hanya berkutat pada pembuatan kalimat, imbuhan, dan bacaan sedangkan fungsi bahasa sebagai alat bernalar, berkomunikasi, dan alat berekspresi diabaikan.

Setiap mahasiswa diharapkan memiliki beberapa kemampuan dalam berbahasa Indonesia. Kemampuan berbahasa ini mencakup kemampuan menyimak (mendengarkan), kemampuan berbicara, kemampuan membaca, dan kemampuan menulis. Keempat kemampuan berbahasa tersebut mutlak diperlukan bagi mahasiswa dalam menunjang dan mendukung aktivitas belajarnya. Berbagai aktivitas tersebut mencakup tugas-tugas perkuliahan (makalah dan laporan ilmiah), berpresentasi, membaca berbagai literatur dan lain-lainnya.

Pembelajaran bahasa Indonesia yang ideal seharusnya memberikan porsi yang sesuai terhadap empat kemampuan berbahasa menurut analisis kebutuhan peserta didik. Selama ini dalam silabus MPK bahasa Indonesia mengutamakan kemampuan menulis saja. Begitu juga pada bahan ajar yang tersedia, banyak yang hanya menekankan pada kemampuan menulis. Padahal ketiga kemampuan berbahasa yang lain juga penting diberikan kepada mahasiswa jurusan nonbahasa berdasarkan pada analisis kebutuhannya. Selain terampil dalam menulis karya ilmiah, mahasiswa juga diharapkan mampu berkomunikasi dengan rekan-rekannya dengan bahasa lisan yang baik dan ilmiah. Hal itu sangat diperlukan dalam tugas presentasi, diskusi maupun dalam mempertahankan tugas akhirnya di hadapan para penguji.

Hasil wawancara kepada beberapa mahasiswa Fakultas Pertanian Universitas Muhammadiyah Palembang pada awal perkuliahan semester II pada tanggal 5 Maret 2013, diketahui bahwa banyak kendala yang ditemui dalam proses pembelajaran bahasa Indonesia. Salah satunya adalah minimnya ketersediaan bahan 
ajar baik berupa buku ajar, modul maupun buku teks. Selama ini mahasiswa hanya bergantung pada materi yang disampaikan oleh dosen-dosen yang bersangkutan. Di sisi lain, bahan ajar yang tersedia selama ini belum tersusun secara baik, salah satunya tidak disusun berdasarkan analisis kebutuhan mahasiswa.

Kondisi dan situasi belajar juga dapat menjadi kendala tersendiri bagi mahasiswa. Kemampuan dalam menerima materi pelajaran bagi mahasiswa berbeda-beda antara satu dengan yang lain. Pembelajaran pada jam-jam terakhir diakui beberapa mahasiswa dapat mengganggu konsentrasi dalam menerima materi pelajaran sehingga diperlukan sebuah modul untuk mengatasinya.

Untuk mengatasi berbagai kendala tersebut diperlukan adanya modul yang lengkap, sistematis, dan menyajikan contoh-contoh yang disesuaikan dengan karakteristik mahasiswa. Modul tersebut penting keberadaannya dalam menunjang kesuksesan pembelajaran. Seyogyanya dosen harus menyiapkan modul yang disusun dan dikembangkan bersama-sama dengan para mahasiswanya agar tercapai tujuan yang diharapkan.

Proses pembelajaran MPK bahasa Indonesia memerlukan sarana pendukung seperti tersedianya bahan ajar. Bahan ajar merupakan bahan atau materi pelajaran yang disusun secara sistematis yang digunakan oleh dosen dan mahasiswa dalam pembelajaran (Panen dikutip Setiawan, 2007:1-5).

Modul memegang peranan yang sangat vital dalam pembelajaran. Selain dapat meningkatkan kualitas pembelajaran dan meningkatkan minat belajar mahasiswa, bahan ajar juga berperan sebagai alat atau bahan untuk meningkatkan keefektifan pembelajaran. Lestari (2013:7) mengemukakan bahwa bahan ajar memiliki fungsi untuk mengarahkan semua aktivitasnya dalam proses pembelajaran sekaligus merupakan substansi kompetensi yang seharusnya diajarkan kepada mahasiswa.

Bahan ajar yang baik seharusnya memenuhi syarat-syarat tertentu. Selain berisikan informasi bidang studi, bahan ajar juga diharapkan dapat meningkatkan kualitas pembelajaran serta memacu minat dan semangat mahasiswa dalam belajar. Salah satu bahan ajar yang memenuhi persyaratan tersebut adalah sebuah modul. 
Modul merupakan salah satu jenis bahan ajar yang berbentuk buku yang disusun dan dirancang bagi peserta didik untuk dapat belajar secara mandiri. Menurut Prastowo (2011:106) modul merupakan sebuah bahan ajar yang dirancang secara sistematis dengan bahasa yang mudah dipahami oleh peserta didik sesuai dengan karakteristiknya, baik tingkat pengetahuannya maupun tingkat usianya. Setiawan dkk. (2007:2.3) mengemukakan bahwa modul adalah bahan ajar yang dapat digunakan untuk berbagai kegiatan, dari menyediakan informasi yang mendasar, bahan instruksi atau petunjuk bagi pembaca, bahan pelengkap dengan ilustrasi foto yang komunikatif, sampai digunakan juga untuk kertas kerja.

Prastowo (2011:107-108) menyatakan bahwa fungsi modul sebagai berikut: (1) bahan ajar mandiri, (2) pengganti fungsi pendidik, (3) sebagai alat evaluasi, dan (4) sebagai bahan rujukan bagi peserta didik. Dengan demikian, modul memiliki fungsi yang lebih unggul dari bahan ajar lainnya karena selain dapat membantu peserta didik belajar mandiri juga dapat membantu siswa yang memiliki kecepatan belajar rendah untuk dapat mengulang materi berkali-kali.

Karakteristik modul yang berbeda dengan bahan ajar yang lain dijadikan pilihan oleh peneliti dalam mengembangkan bahan ajar. Fungsi modul sebagai pengganti fungsi pendidik diharapkan dapat menuntun mahasiswa dalam mengulang materi yang telah diberikan oleh dosen. Artinya dengan modul ini diharapkan dapat membantu mahasiswa dalam mengatasi berbagai kendala dalam pembelajaran termasuk keterlambatan proses penerimaan materi oleh mahasiswa pada saat jam belajar.

Beberapa penelitian pengembangan bahan ajar di perguruan tinggi sudah pernah dilakukan oleh beberapa peneliti sebelumnya. Penelitian tentang modul dilakukan oleh Ipriansyah pada tahun 2011. Penelitian ini mengembangkan modul membaca cerita pendek kelas X SMA Negeri 1 Jarai. Dalam penelitian tersebut diketahui adanya peningkatan pemahaman terhadap membaca cerpen dari hasil tes menceritakan kembali isi cerpen.

Pada tahun 2012, penelitian pengembangan bahan ajar juga dilakukan oleh Aryanti Agustina tentang bahan ajar menulis I di Universitas Baturaja. Penelitian ini menghasilkan modul menulis I yang telah diujicobakan kepada mahasiswa. 
Hasil penelitian tersebut menunjukkan adanya peningkatan pemahaman dan kemampuan menulis mahasiswa Program Studi Pendidikan Bahasa dan Sastra Indonesia di Universitas Baturaja.

Penelitian tentang modul matakuliah umum bahasa Indonesia pernah dilakukan oleh Iwan Setiawan pada tahun 2009 (Pascasarjana Universitas Negeri Malang). Penelitian tersebut berjudul Pengembangan Modul Pembelajaran Matakuliah Bahasa Indonesia pada Fakultas Hukum Universitas Wisnuwardahana Malang. Hasil akhir dari penelitian tersebut mencakup: (1) uraian materi disusun berdasarkan analisis kebutuhan, (2) uraian materi disusun secara sistematis dan logis, (3) penyajian isi materi diawali dengan hubungan antara bahasa dengan hukum, (4) bentuk self-assesment dalam mencapai tujuan pembelajaran, dan (5) penekanan pada penggunaan modul secara mandiri, baik belajar yang bersifat selfcontained maupun self-directed(http://karyailmiah.um.ac.id/index.php/disertasi/article/view/1876).

Penelitian pengembangan yang dilakukan oleh peneliti ini tentu berbeda dengan penelitian pengembangan sebelumnya. Perbedaannya adalah pada modul matakuliah yang dikembangkan. Penelitian dan pengembangan modul MPK bahasa Indonesia ini belum pernah dikembangkan sebelumnya oleh peneliti lain di Universitas Sriwijaya. Perbedaan lainnya adalah subjek penelitian yang diambil dari mahasiswa Fakultas Pertanian yang merupakan jurusan nonbahasa.

Berdasarkan uraian di atas, sebuah bahan ajar yang berupa modul pembelajaran MPK bahasa Indonesia untuk mahasiswa Fakultas Pertanian Universitas Muhammadiyah Palembang diperlukan sebagai upaya untuk meningkatkan kemampuan berbahasa Indonesia khususnya dalam menulis akademik, membaca untuk menulis, dan berbicara untuk keperluan akademik bagi mahasiswa. Penelitian pengembangan ini dilakukan melalui langkah-langkah penelitian dalam menghasilkan modul pembelajaran MPK bahasa Indonesia yang sesuai dengan kebutuhan mahasiswa dan para dosen di Universitas Muhammadiyah Palembang. 


\section{B. Rumusan Masalah}

Berdasarkan latar belakang di atas, maka permasalahan penelitian ini dapat dirumuskan secara rinci dalam bentuk beberapa pertanyaan berikut ini.

1) Bagaimanakah kebutuhan modul menurut mahasiswa dan dosen terhadap pengembangan modul MPK bahasa Indonesia?

2) Bagaimanakah rancangan modul yang sesuai dengan kebutuhan mahasiswa dalam Matakuliah Pengembangan Kepribadian (MPK) bahasa Indonesia?

3) Bagaimanakah modul MPK bahasa Indonesia untuk mahasiswa Fakultas Pertanian Universitas Muhammadiyah Palembang hasil pengembangan?

4) Bagaimanakah uji keefektifan pengembangan modul MPK bahasa Indonesia terhadap hasil belajar mahasiswa?

\section{Tujuan Penelitian}

Berdasarkan permasalahan tersebut, tujuan penelitian ini secara umum adalah terbentuknya modul MPK bahasa Indonesia untuk mahasiswa Semester II Fakultas Pertanian Universitas Muhammadiyah Palembang yang dijabarkan sebagai berikut.

1) Mendeskripsikan hasil kebutuhan mahasiswa dan dosen terhadap pengembangan bahan ajar MPK bahasa Indonesia.

2) Mendeskripsikan rancangan modul yang sesuai dengan analisis kebutuhan mahasiswa dalam MPK bahasa Indonesia

3) Mendeskripsikan modul MPK bahasa Indonesia hasil pengembangan.

4) Mengetahui hasil uji keefektifan pengembangan modul MPK bahasa Indonesia terhadap hasil belajar siswa.

\section{Manfaat Penelitian}

Secara teoretis, pengembangan bahan ajar berupa modul MPK bahasa Indonesia dapat dijadikan sebagai tambahan literatur dan referensi dalam pengembangan bahan ajar.

Secara praktis, diharapkan penelitian ini dapat menghasilkan modul MPK bahasa Indonesia dan menambah bahan pembelajaran yang telah ada. Bagi dosen, 
hasil penelitian ini diharapkan mampu memberikan alternatif lain dalam mengembangkan pola pembelajaran MPK bahasa Indonesia. Selain itu juga diharapkan modul ini dapat menambah wawasan bagi dosen atau tenaga pengajar dalam pemilihan bahan ajar.

Bagi mahasiswa, modul ini diharapkan dapat dijadikan pedoman dan pegangan dalam pembelajaran bagi mahasiswa semester II Fakultas Pertanian Universitas Muhammadiyah Palembang yang menjadi subjek dalam penelitian ini. Di samping itu, keberadaan modul ini diharapkan dapat memberikan wawasan dan pengetahuan bahwa bahasa Indonesia sangat penting bagi mahasiswa dalam menyelesaikan studi, khususnya dalam penyusunan tugas akhir mahasiswa.

Bagi institusi atau lembaga, hasil penelitian ini diharapkan dapat memberikan sumbangan untuk meningkatkan kualitas pembelajaran. Bagi peneliti hasil penelitian ini diharapkan dapat menambah pengetahuan dalam mengembangkan bahan ajar yang lebih kreatif dan menarik pada penelitian selanjutnya.

\section{KAJIAN PUSTAKA}

\section{A. Bahan Ajar}

Ada berbagai definisi bahan ajar yang dikemukakan oleh para ahli. Bahan ajar atau materi pembelajaran merupakan semua bentuk bahan yang digunakan oleh guru atau dosen untuk membantu dalam pelaksanaan pembelajaran di kelas yang terdiri dari pengetahuan, keterampilan, dan sikap (Depdiknas, 2006:4). Widodo \& Jasmadi dikutip Lestari (2013:1) menyatakan bahan ajar adalah seperangkat sarana atau alat pembelajaran yang berisikan materi pembelajaran, metode, batasanbatasan, dan cara mengevaluasi yang disusun secara sistematis untuk mencapai tujuan yang diharapkan. Bahan ajar dapat dipahami sebagai segala bahan baik informasi, alat, maupun teks yang disusun secara sistematis yang menampilkan secara utuh dari kompetensi yang akan dikuasai peserta didik dan digunakan dalam proses pembelajaran (Prastowo, 2011:17). Menurut Panen dikutip Setiawan (2007:1.5) bahwa bahan ajar adalah bahan atau materi pelajaran yang disusun secara sistematis, yang digunakan guru dan siswa dalam proses pembelajaran. 
Berdasarkan beberapa definisi di atas dapat disimpulkan bahwa bahan ajar adalah semua perangkat pembelajaran atau materi pembelajaran yang yang disusun secara sistematis untuk keperluan suatu proses pembelajaran. Pada dasarnya bahan ajar digunakan untuk mempermudah proses pembelajaran di kelas. Bahan ajar tidak hanya mencakup tentang pengetahuan (fakta, konsep, prinsip, dan prosedur), tetapi juga mencakup keterampilan dan sikap atau nilai.

Bahan ajar bersifat unik dan spesifik. Unik artinya bahan ajar tersebut hanya dapat digunakan untuk peserta didik tertentu dan dalam suatu proses pembelajaran tertentu. Spesifik artinya bahwa isi dari bahan ajar itu dirancang/disusun semenarik mungkin untuk mencapai tujuan tertentu. Sistematika penyampaiannya pun berbeda, artinya cara menyampaikan materi tersebut disesuaikan dengan karakteristik mata pelajaran dan karakteristik peserta didik yang menggunakannya.

Bahan ajar juga memiliki beberapa karakteristik. Tidak semua buku yang beredar di publik dapat digolongkan dalam bahan ajar. Menurut Widodo \& Jasmadi dikutip Lestari (2013:2-3) karakteristik bahan ajar mencakup (1) bahan ajar mampu membelajarkan diri sendiri, (2) materi pelajaran dari satu unit kompetensi terdapat di dalam satu bahan ajar secara utuh, (3) berdiri sendiri, (4) memiliki daya adaptif yang tinggi terhadap perkembangan ilmu pengetahuan dan teknologi, dan (5) mudah digunakan.

\section{B. Fungsi dan Peranan Bahan Ajar}

Bahan ajar memiliki fungsi yang sangat penting dalam proses pembelajaran. Bahan ajar juga sangat menentukan kualitas dan hasil pembelajaran. Lestari (2013:7) menyatakan fungsi bahan ajar secara garis besar adalah untuk memfokuskan semua aktivitas dalam proses pembelajaran dan juga sebagai alat evaluasi pencapaian hasil pembelajaran.

Bahan ajar sangat penting peranannya bagi dosen dan mahasiswa. Bagi dosen, bahan ajar sangat berperan dalam menghemat waktu mengajar, mengubah peran dosen menjadi fasilitator, dan mewujudkan pembelajaran yang lebih efektif dan interaktif. Bagi mahasiswa, bahan ajar dapat membantu mahasiswa dalam 
mempelajari materi dan membantu kemampuan mereka dalam belajar secara mandiri.

Peranan bahan ajar dalam pembelajaran dapat dimanfaatkan sebagai bahan utama dan bahan pelengkap. Dalam pembelajaran individual, bahan ajar sebagai bahan ajar utama sedangkan dalam pembelajaran klasikal bahan ajar sebagai bahan pelengkap buku utama.

\section{Jenis-jenis Bahan Ajar}

Jenis-jenis bahan ajar berdasarkan teknologi atau media yang digunakan meliputi: (1) bahan ajar cetak (printed) seperti modul, lembar kerja siswa (LKS), handout, buku ajar, foto/gambar, model/maket, leaflet, dan wallchart, (2) bahan ajar dengar (audio) seperti kaset, radio, piringan hitam, dan compact disc audio, (3) bahan ajar pandang dengar (audio visual) seperti video compact disc (VCD), digital compact disc (DVD), dan film, (4) bahan ajar multimedia interaktif (interactive teaching material) seperti Computer Assisted Instruction (CAI), Compact Disc (CD) multimedia pembelajaran interaktif, dan bahan ajar berbasis jaringan (Ellington dikutip Setiawan, 2007:1.7).

Bahan ajar juga dapat dibedakan menurut bentuknya, cara kerjanya, dan sifatnya (Prastowo, 2011:40). Bahan ajar berdasarkan bentuknya seperti bahan ajar cetak, bahan ajar audio, bahan ajar pandang dengar (audio video), dan bahan ajar interaktif. Bahan ajar menurut cara kerjanya terdiri atas bahan ajar yang tidak diproyeksikan, bahan ajar yang diproyeksikan, bahan ajar audio, bahan ajar video, dan bahan ajar media komputer. Bahan ajar menurut sifatnya terdiri atas bahan ajar yang berbasiskan cetak, bahan ajar berbasiskan teknologi, bahan ajar untuk proyek (praktik), dan bahan ajar yang dibutuhkan untuk keperluan interaksi manusia.

Pada penelitian pengembangan ini, peneliti mengembangkan bahan ajar cetak (printed) berupa modul. Bahan ajar ini merupakan bahan ajar yang dapat menuntun mahasiswa belajar secara mandiri. Artinya, mahasiswa dapat belajar sendiri dengan panduan modul tersebut tanpa bimbingan dosen. 


\section{Pengembangan Bahan Ajar}

Pada dasarnya pengembangan bahan ajar harus dilakukan secara sistematis dan sesuai dengan langkah-langkah yang saling berkaitan untuk menghasilkan bahan ajar yang berkualitas. Tomlison (1998:2) menyatakan bahwa pengembangan bahan ajar merujuk pada segala sesuatu yang dilakukan oleh penulis, guru/dosen, dan peserta didik dalam menyediakan sumber belajar untuk memaksimalkan pengalaman yang disusun untuk meningkatkan pembelajaran.

Proses pengembangan bahan ajar harus disesuaikan dengan analisis kebutuhan dan tetap memperhatikan prinsip-prinsip pengembangan bahan ajar. Depdiknas (2008:10) menyatakan bahwa prinsip-prinsip pengembangan bahan ajar meliputi (1) mengawali dari yang mudah dipahami sampai kepada yang tersulit, dari yang konkret menuju yang abstrak; (2) pengulangan akan memperkuat pemahaman; (3) umpan balik positif akan memberikan penguatan terhadap pemahamana siswa; (4) motivasi belajar yang tinggi merupakan salah satu faktor penentu keberhasilan siswa; (5) mencapai tujuan setahap demi setahap; (6) mengetahui hasil yang telah dicapai akan mendorong siswa untuk terus mencapai tujuan.

Bahan ajar yang dikembangkan dalam penelitian ini adalah modul. Modul pembelajaran bahasa Indonesia tersebut disesuaikan dengan aspek kompetensi yang dikembangkan. Produk akhir dari pengembangan ini adalah modul yang bersifat fleksibel. Penerapan dan menyampaian modul hasil pengembangan ini dilakukan melalui kegiatan pembelajaran di kelas.

\section{E. Analisis Kebutuhan Bahan Ajar}

Pengembangan bahan ajar dalam dunia pendidikan sangat diperlukan dengan berbagai alasan. Kekurangan bahan ajar sebagai salah satu sumber bahan ajar dapat dijadikan alasan bagi guru atau dosen untuk mengembangkan bahan ajar. Tersedianya bahan ajar yang tidak sesuai dengan kebutuhan dosen dan mahasiswa atau kurikulum juga dapat menjadi alasan untuk mengembangkan model lain dari bahan ajar baru. 
Langkah awal dalam mengembangkan bahan ajar adalah melakukan serangkaian analisis terhadap kebutuhan siswa dan dosen. Prastowo (2011:50) menyatakan bahwa analisis kebutuhan bahan ajar merupakan suatu proses awal yang dilakukan untuk menyusun bahan ajar yang sesuai dengan kebutuhan siswa. Analisis kebutuhan juga dapat diartikan sebagai proses awal dalam penentuan tujuan-tujuan perilaku yang akan dicapai (Nurhayati, 2012:29). Menurut Nunan (1992:45) analisis kebutuhan merupakan seperangkat prosedur untuk menetapkan parameter tertentu dalam sebuah program. Dengan adanya analisis kebutuhan ini maka pengembangan bahan ajar akan lebih terarah.

Analisis kebutuhan siswa dilakukan karena beberapa tujuan. Menurut Richard dikutip Nurhayati (2012:29) analisis kebutuhan mempunyai beberapa tujuan utama yaitu: (1) analisis ini dapat digunakan sebagai sarana pemerolehan input yang lebih luas tentang isi, desain, dan implementasi tentang program bahasa, (2) dapat digunakan untuk mengembangkan tujuan dan isi dan program, (3) dapat menyediakan data bagi penelaahan dan penilaian program yang sedang berjalan.

\section{F. Bahan Ajar Berbentuk Modul}

Seperti yang telah dikemukakan sebelumnya bahwa bahan ajar dapat berbentuk cetak dan noncetak. Salah satu contoh bahan ajar cetak (tertulis) adalah modul. Modul merupakan sebuah bahan ajar yang disusun secara sistematis yang bahasa mudah dipahami oleh peserta didik sesuai dengan tingkat pengetahuan dan usianya, agar mereka dapat belajar secara mandiri (Prastowo, 2011:106).

Menurut Lestari (2012:6) modul adalah bahan ajar yang ditulis dengan tujuan agar peserta didik dapat belajar secara mandiri tanpa atau dengan bimbingan dosen/guru, oleh karena itu sebuah modul harus berisi petunjuk belajar yang lengkap dan sistematis.

Dari uraian tersebut dapat disimpulkan bahwa modul adalah bahan tertulis yang disusun dan didesain dengan tujuan agar peserta didik dapat belajar secara mandiri tanpa bimbingan guru. Sebuah modul berisi tentang (1) petunjuk belajar bagi guru dan siswa; (2) kompetensi yang ingin dicapai; (3) informasi pendukung; 
(4) latihan-latihan; (5) petunjuk kerja yang berupa lembar kerja; dan (6) evaluasi (Depdiknas, 2008:13).

Dalam menyusun modul harus mengikuti tahapan-tahapan yang meliputi: (1) analisis terhadap standar kompetensi (SK) dan kompetensi dasar (KD) untuk menentukan materi mana yang memerlukan bahan ajar, (2) menentukan judul-judul modul berdasarkan atas materi pembelajaran dalam silabus, (3) pengkodean modul untuk memudahkan dalam pengelolaannya, (4) mengikuti langkah-langkah penulisan modul yang mencakup rumusan $\mathrm{KD}$, penentuan alat evaluasi, penyusunan materi, pengurutan pembelajaran, dan struktur modul (Depdiknas, 2008:23).

Pada penelitian ini jenis bahan ajar yang dikembangkan adalah modul pembelajaran MPK bahasa Indonesia. Modul yang dikembangkan harus memiliki kerangka yang lengkap. Kerangka tersebut dikembangkan dari buku Pedoman Pengembangan Bahan Ajar dari Depdiknas sebagai berikut.

1. Isi modul sesuai dengan tujuan

2. Memiliki urutan yang tepat

3. Memuat petunjuk penggunaan bahan ajar

4. Materi dan informasi pendukung

5. Adanya soal latihan

6. Jawaban latihan

7. Adanya rangkuman

8. Soal tes formatif

9. Kunci jawaban tes formatif, dan

10. Daftar pustaka.

Berdasarkan kerangka pengembangan modul tersebut dapat dilihat pada bagan berikut. 


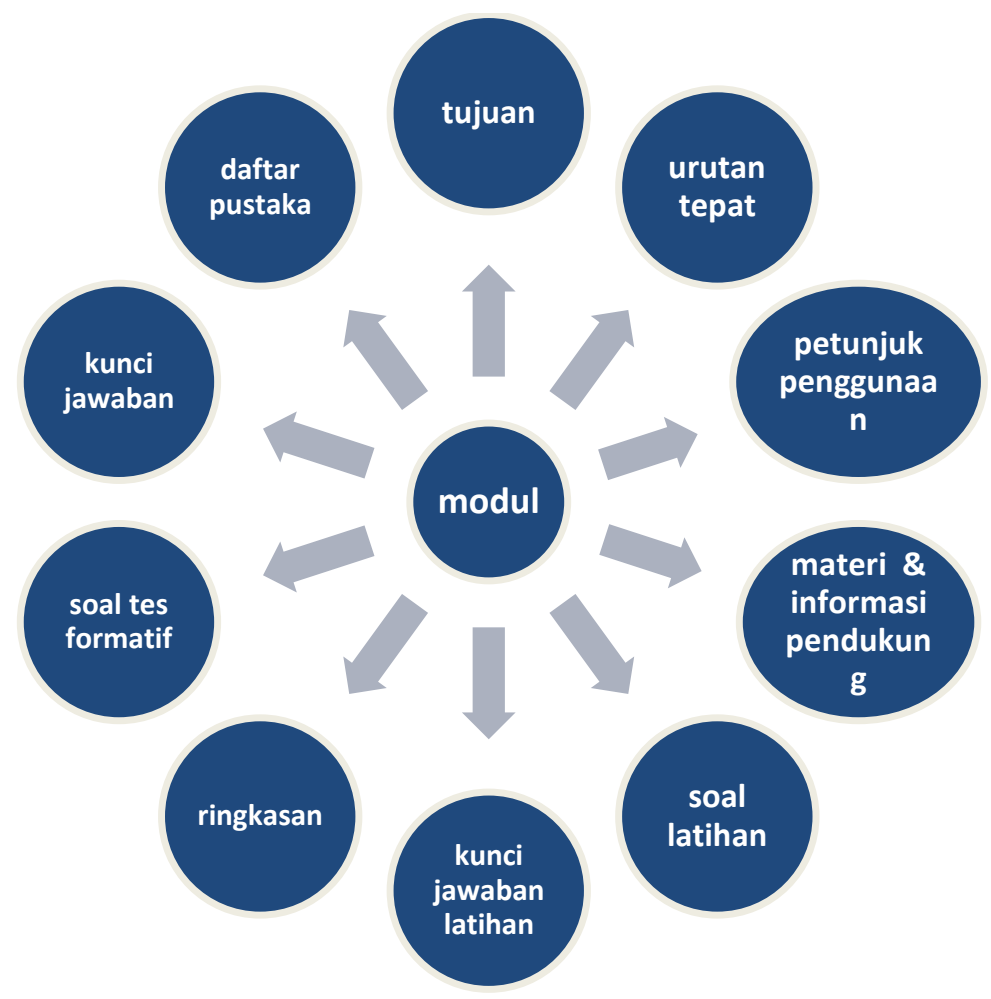

Bagan 1. Kerangka Pengembangan Modul

\section{G. Pengembangan Modul}

Pengembangan modul dapat dilakukan dengan berbagai cara, seperti yang dikemukakan oleh Purwanto (2007:10—12) sebagai berikut.

a. Modul adaptasi

Modul adaptasi merupakan bahan ajar yang dikembangkan atas dasar buku yang beredar di publik.

b. Modul Kompilasi

Modul kompilasi merupakan jenis bahan ajar yang dikembangkan atas dasar buku yang beredar di publik, artikel-artikel ilmiah, dan modul yang sudah ada sebelumnya. Ada beberapa prosedur dalam menyusun modul kompilasi yaitu.

1. Kumpulkan seluruh buku, artikel jurnal ilmiah, modul dan sumber lain yang digunakan dalam mata kuliah. 
2. Tentukan bagian-bagian buku, artikel jurnal ilmiah, modul dan bagian dari sumber acuan lain yang digunakan per pokok bahasan.

3. Fotokopi seluruh bagian dari sumber yang digunakan per pokok bahasan.

4. Pilihlah hasil fotokopi tersebut berdasarkan pokok bahasan.

5. Buat tulisan halaman penyekat bahan untuk setiap pokok bahasan.

6. Bahan-bahan yang sudah dilengkapi dengan halaman penyekat untuk setiap pokok bahasan kemudian dijilid rapi.

c. Modul Pengembangan sendiri

Modul hasil pengembangan sendiri merupakan sebuah modul yang ideal. Modul ini sangat cocok dipergunakan dalam pembelajaran karena disusun sesuai dengan analisis kebutuhan dari mahasiswa dan dosen.

\section{H. Evaluasi Bahan Ajar}

Evaluasi bahan ajar sangat penting peranannya dalam proses pengembangan bahan ajar. Hasil evaluasi tersebut diharapkan menjadi umpan balik terhadap kualitas bahan ajar yang disusun penulisnya. Evaluasi bahan ajar juga dapat menentukan kelayakan bahan ajar tersebut sebagai bahan dan media pembelajaran. Di samping itu, evaluasi bahan ajar juga diharapkan dapat menghasilkan suatu produk bahan ajar yang sesuai dengan kebutuhan penggunaanya.

Komponen-komponen evaluasi mencakup empat bagian. Komponen tersebut adalah komponen kelayakan isi, kebahasaan, sajian, dan kegrafikaan. Keempat komponen tersebut saling berkaitan erat dan menjadi satu kesatuan komponen dalam bahan ajar.

Penelitian ini menggunakan dua metode evaluasi, yaitu evaluasi sebelum dan sesudah bahan ajar digunakan kepada mahasiswa. Evaluasi sebelum adalah evaluasi yang dilakukan oleh pakar atau ahli untuk mengetahui kekurangankekurangan dan kelebihan bahan ajar tersebut untuk digunakan. Hasil evaluasi ini 
akan dijadikan masukan untuk melakukan revisi/perbaikan atau bahkan perubahan terhadap bahan ajar. Evaluasi sesudah yaitu evaluasi terhadap mahasiswa yang sudah menggunakan bahan ajar yang dikembangkan untuk melihat progres dan kemajuan hasil belajarnya.

\section{Substansi Kajian Matakuliah Bahasa Indonesia}

Menurut Surat Keputusan Direktorat Jenderal Pendidikan Tinggi Departemen Pendidikan Nasional Nomor 43 tahun 2006, substansi kajian untuk Matakuliah Pengembangan Kepribadian (MPK) bahasa Indonesia meliputi: (1) kedudukan bahasa Indonesia, (2) menulis akademik, (3) membaca untuk menulis, dan (4) berbicara akademik.

Struktur kajian kedudukan bahasa Indonesia terdiri atas sejarah bahasa Indonesia, bahasa negara, bahasa persatuan, bahasa ilmu pengetahuan, teknologi dan seni, dan fungsi serta peran bahasa Indonesia dalam pembangunan bangsa. Kajian menulis akademik meliputi menulis makalah, rangkuman/ringkasan buku atau bab, dan resensi buku. Kajian membaca untuk menulis terdiri atas membaca artikel/artikel ilmiah, membaca tulisan populer, dan mengakses informasi melalui internet. Substansi kajian yang terakhir adalah berbicara akademik yang mencakup berbicara untuk presentasi, berseminar, dan berpidato dalam situasi formal.

\section{Kedudukan Bahasa Indonesia}

Bahasa Indonesia berasal dari bahasa Melayu yang masuk dalam rumpun bahasa Austronesia. Bahasa ini merupakan bahasa yang dijadikan sebagai lingua franca di nusantara sejak beberapa abad yang lalu. Menurut Rahayu (2007:8) bahasa Indonesia adalah bahasa Melayu yang telah menyatu dengan bahasa daerah dan bahasa asing yang berkembang di Indonesia. Awal penamaan bahasa Indonesia berawal dari Sumpah Pemuda pada tanggal 28 Oktober 1928. Pada ikrar ketiga yang berbunyi Kami putra dan putri Indonesia menjunjung tinggi bahasa persatuan, bahasa Indonesia menunjukkan bahwa bahasa Indonesia berkedudukan sebagai bahasa nasional di atas bahasa-bahasa daerah. 
Pemilihan bahasa Melayu menjadi bahasa Indonesia didasarkan atas pertimbangan yang rasional, baik secara politik, ekonomi, dan kebahasaan, yaitu: (1) bahasa Melayu telah tersebar luas di seluruh wilayah Indonesia, (2) bahasa Melayu diterima oleh semua suku di Indonesia, karena telah dikenal dan digunakan sebagai bahasa pergaulan, tidak lagi dirasakan sebagai bahasa asing, (3) bahasa Melayu bersifat demokratis artinya tidak membeda-bedakan tingkatan dalam pemakaian sehingga meniadakan sifat feodal dan memudahkan orang mempelajarinya, dan (4) bahasa Melayu bersifat reseptif artinya mudah menerima masukan dari bahasa daerah lain dan bahasa asing sehingga mempercepat perkembangan bahasa Indonesia di masa mendatang.

Beberapa peristiwa penting yang berkaitan dengan perkembangan bahasa Indonesia di antaranya:

1. tahun 1901, disusun ejaan resmi bahasa Melayu oleh Ch. A. Van Ophuijsen

2. tahun 1908, pemerintah sebuah badan penerbit buku-buku bacaan yang diberi nama Commssie voor de Volkslectuur (Taman Bacaan Rakyat)

3. tanggal 28 Oktober 1928 pada momentum sumpah pemuda

4. tahun 1933, berdirinya angkatan sastrawan muda yang menamakan dirinya sebagai Pujangga Baru

5. tanggal 25-28 juni 1938, dilaksanakan kongres Bahasa Indonesia I di Solo

6. tanggal 18 Agustus 1945, berlakunya Undang-Undang Dasar 1945 (salah satunya pasal 36 yang berisi tentang bahasa negara adalah bahasa Indonesia)

7. tanggal 19 Maret 1947, diresmikan Ejaan Republik (Ejaan Soewandi) sebagai pengganti Ejaan Van Ophuijsen

8. tanggal 28 Oktober-2 November 1954, kongres bahasa Indonesia II di Medan

9. tanggal 16 Agustus 1972, presiden Soeharto meresmikan penggunaan Ejaan Bahasa Indonesia Yang disempurnakan (EYD) 
10. tanggal 31 Agustus 1972, Menteri Pendidikan dan Kebudayaan mengesahkan Pedoman Umum Ejaan Bahasa Indonesia Yang disempurnakan dan Pedoman Umum Pembentukan Istilah resmi berlaku di seluruh wilayah Indonesia

11. tanggal 28 Oktober-2 November 1978, kongres bahasa Indonesia III yang diselenggarakan di Jakarta

12. tanggal 21-26 Desember 1983, kongres bahasa Indonesia IV diselenggarakan di Jakarta

13. tanggal 28 Oktober-3 November 1988, kongres bahasa Indonesia V diselenggarakan di Jakarta

14. tanggal 28 Oktober-2 November 1993, kongres bahasa Indonesia VI diselenggarakan di Jakarta

15. tanggal 26-30 Oktober 1998, kongres bahasa Indonesia VII diselenggarakan di Hotel Indonesia, Jakarta

16. tanggal 14-17 Oktober 2003, kongres bahasa Indonesia VIII diselenggarakan di Jakarta

17. tanggal 28 September-1 Oktober 2008, kongres IX bahasa Indonesia di Jakarta.

Bahasa Indonesia berkedudukan sebagai bahasa nasional dan bahasa bahasa negara. Bahasa Indonesia sebagai bahasa nasional berfungsi sebagai (1) lambang kebanggaan nasional, (2) lambang identitas nasional, (3) alat pemersatu berbagai masyarakat yang berbeda latar belakang sosial budaya dan bahasanya, dan (4) alat perhubungan antar daerah. Bahasa Indonesia berkedudukan sebagai bahasa negara, berfungsi sebagai (1) bahasa resmi negara, (2) bahasa pengantar resmi di lembagalembaga pendidikan, (3) bahasa resmi dalam perhubungan pada tingkat nasional, dan (4) bahasa resmi di dalam pembangunan kebudayaan dan pemanfaatan ilmu pengetahuan serta teknologi (Suwandi dkk, 2007: 2-3).

Bahasa Indonesia dinyatakan kedudukannya sebagai bahasa negara pada tanggal 18 Agustus 1945. Hal itu tertuang dalam Undang-Undang Dasar 1945 Bab XV pasal 36 yang berbunyi Bahasa negara ialah bahasa Indonesia. Dengan 
berlakunya UUD 1945, bertambah pula kedudukan bahasa Indonesia, yaitu sebagai bahasa negara dan bahasa resmi. Sebagai bahasa negara, bahasa Indonesia digunakan dalam berbagai kegiatan seperti upacara, peristiwa nasional, dan kegiatan kenegaraan. Di samping itu, dokumen-dokumen, undang-undang, peraturan-peraturan pemerintah, dan surat-menyurat yang dikeluarkan oleh pemerintah dan instansi kenegaraan lainnya harus ditulis dalam bahasa Indonesia.

Selain sebagai bahasa negara, bahasa Indonesia juga mengemban tugas sebagai bahasa persatuan. Dengan menggunakan bahasa Indonesia, rasa kesatuan dan persatuan bangsa yang terdiri dari berbagai etnis akan terpupuk. Kehadiran dan penggunaan bahasa Indonesia diharapkan juga dapat menghilangkan sentimen negatif bagi etnis yang menggunakannya. Sebaliknya, justru dengan kehadiran bahasa Indonesia dianggap sebagai penengah ego kesukuan dan sentimen kedaerahan.

Pemerintah juga mengatur tentang bahasa Indonesia dalam Undang-Undang Nomor 24 tahun 2009 tentang Bendera, Bahasa, dan Lambang negara, serta Lagu Kebangsaan. Undang-Undang ini dibuat bertujuan untuk memperkuat persatuan dan kesatuan, menjaga kehormatan yang menunjukkan kedaulatan bangsa, dan menciptakan ketertiban, kepastian, dan standarisasi penggunaan bahasa Indonesia. Pengaturan bahasa Indonesia dalam Undang-Undang ini dijabarkan pada Bab III pasal 25 sampai dengan pasal 45.

Dalam perkembangannya, bahasa Indonesia juga berfungsi sebagai bahasa pendukung ilmu pengetahuan dan teknologi (IPTEK) dan seni untuk kepentingan nasional. Penyebarluasan IPTEK dan pemanfaatannya kepada perencanaan dan pelaksanaan pembangunan negara dilakukan dengan menggunakan bahasa Indonesia. Bahasa Indonesia dijadikan pula sebagai bahasa pengantar dalam dunia pendidikan khususnya di lembaga-lembaga dan institusi pendidikan. Dengan demikian, masyarakat Indonesia tidak bergantung kepada bahasa-bahasa asing dalam mengikuti perkembangan dan penerapan IPTEK.

Di samping itu, bahasa Indonesia memiliki fungsi dan peran dalam pembangunan bangsa. Peran bahasa Indonesia tampak dalam kehidupan bermasyarakat di berbagai wilayah Indonesia. Hubungan komunikasi pada berbagai 
kegiatan masyarakat bahasa Indonesia sebagai wahana dan piranti untuk membangun kesepahaman, kesepakatan, dan persepsi yang memungkinkan terjadinya kelancaran pembangunan masyarakat di berbagai bidang.

\section{Bahasa Indonesia yang Baik dan Benar}

Dalam bahasa Indonesia dikenal istilah bahasa Indonesia yang baik dan benar. Bahasa yang baik belum tentu bahasa yang benar sedangkan bahasa yang benar sudah tentu bahasa yang baik. Finoza (2003:11) menyatakan bahwa bahasa dikatakan baik apabila maknanya dapat dimengerti oleh komunikan dan ragamnya sudah sesuai dengan situasi pada saat bahasa tersebut digunakan. Senada dengan pendapat tersebut, Haryadi dan Ismail (2010:4) menyatakan bahwa bahasa yang baik adalah bahasa Indonesia yang digunakan sesuai dengan norma kemasyarakatan yang berlaku.

Bahasa Indonesia yang benar adalah bahasa Indonesia yang digunakan sesuai dengan aturan atau kaidah bahasa Indonesia yang berlaku yang meliputi kaidah ejaan, pembentukan kata, penyusunan kalimat, penyusunan paragraf, dan penataan penalaran (Haryadi \&Ismail, 2010:4). Bahasa yang benar merupakan bahasa yang sesuai dengan kaidah bahasa baku (Finoza, 2003:11).

Dari penjelasan beberapa pendapat di atas, dapat disimpulkan bahasa Indonesia yang baik dan benar adalah bahasa Indonesia yang digunakan sesuai dengan situasi dan norma kemasyarakatan yang berlaku dan sesuai dengan kaidah bahasa Indonesia yang dibakukan. Kriteria yang dapat dijadikan untuk melihat penggunaan bahasa yang benar adalah kaidah bahasa meliputi aspek fonologi, tata bahasa, kosakata, ejaan, dan makna, sedangkan kriteria untuk melihat penggunaan bahasa yang baik adalah ketepatan memilih ragam bahasa yang sesuai dengan kebutuhan komunikasi (Sugono, 2009:22-23).

\section{Bahasa Akademik/Ilmiah}

Ragam bahasa Indonesia terdiri atas beberapa macam di antaranya adalah bahasa akademik atau bahasa ilmiah. Bahasa Ilmiah atau Akademik merupakan sarana verbal yang digunakan untuk mengkomunikasikan proses kegiatan dan hasil 
penalaran ilmiah (Widjono, 2005:21). Menurut Alex (2011:170) ragam bahasa ilmiah/akademik merupakan ragam bahasa berdasarkan pengelompokkan menurut jenis pemakaiannya dalam bidang kegiatan sesuai dengan sifat keilmuannya.

Berdasarkan pendapat-pendapat di atas dapat disimpulkan bahasa akademik/ilmiah adalah ragam bahasa yang digunakan dengan dunia akademik yang berdasarkan pada penalaran ilmiah yang biasanya digunakan pada bahasa makalah, proposal, skripsi, tesis, dan desertasi.

\section{Menulis Akademik}

Menulis merupakan salah satu keterampilan berbahasa yang keempat. Musaba (2012:24) menyatakan bahwa menulis merupakan kegiatan mengungkapkan pikiran, perasaan, pengalaman, dan hal-hal lainnya melalui tulisan. Menurut Alex (2011:106) hakikat menulis adalah sebuah kegiatan untuk menciptakan atau informasi pada suatu media dengan menggunakan aksara. Pamungkas (2012:57) menyatakan bahwa menulis merupakan sebuah wujud atau cara berkomunikasi dengan menggunakan media.

Dalam dunia pendidikan dikenal menulis akademik. Menulis akademik adalah jenis menulis yang dilakukan dalam dunia pendidikan baik di sekolah maupun di universitas. Menulis jenis ini berbeda dengan menulis secara personal. Perbedaannya terdapat pada pembaca yang khusus, tone, dan tujuannya (Oshima dan Ann Hogue, 1999:2).

Menulis akademik merupakan sebuah proses yang tidak bisa digolongkan ke dalam kegiatan sederhana. Proses menulis jenis ini pada hakikatnya merupakan kegiatan yang bersifat kompleks/rumit. Menulis dilakukan dalam beberapa tahap, yakni tahap prapenulisan, tahap penulisan, dan tahap revisi (Rahayu, 2007:136). Senada dengan pendapat di atas, Oshima dan Ann Hogue (1999:3-12) juga menyatakan beberapa langkah-langkah dalam menulis, meliputi: (1) pramenulis, (2) perencanaan, (3) menulis, (4) merevisi, (5) menulis ulang, dan (6) menulis hasil revisi yang sudah final.

Salah satu wujud dari keterampilan menulis akademik adalah menulis makalah. Dalam pembelajaran seluruh mata kuliah di perguruan tinggi, sebagian 
besar menekankan pada mahasiswa untuk menulis makalah. Menurut Kamus Besar Bahasa Indonesia, makalah dapat diartikan sebagai tulisan resmi tentang pokok yang dimaksudkan untuk dibacakan di muka umum. Alex (2011:111) menyatakan bahwa makalah adalah tulisan resmi tentang suatu pokok yang ditujukan untuk dibacakan di muka umum dalam suatu persidangan atau seminar. Menurut Pamungkas (2012:63) makalah merupakan salah satu jenis karya ilmiah yang ditulis untuk memenuhi tugas matakuliah tertentu untuk memberikan saran pemecahan tentang suatu masalah tertentu secara ilmiah.

Seperti halnya karya ilmiah lainnya, makalah mempunyai tiga bagian utama, yaitu bagian awal, bagian inti, dan bagian akhir. Bagian awal terdiri atas sampul luar, daftar isi, dan daftar tabel. Bagian inti terdiri atas latar belakang, rumusan masalah, tujuan penulisan makalah, pembahasan, kesimpulan, dan saransaran. Bagian akhir terdiri atar daftar rujukan (daftar pustaka) dan lampiran.

Contoh lain dalam keterampilan menulis ini adalah resensi buku. Resensi berasal dari bahasa Latin yaitu revidere dan resence, artinya melihat kembali, menimbang, atau menilai. Di Indonesia resensi sering juga disebut timbangan buku, tinjauan buku, dan bedah buku. Menurut Webstar College Dictionary dikutip Alex (2011:131) resensi buku pada hakikatnya haruslah menjelaskan apa adanya suatu buku tersebut, yaitu kelebihan dan kekurangan buku itu.

Pendapat lain dikemukakan oleh Widjono (2005:273) yang mengungkapkan bahwa resensi adalah ulasan atau penilaian sebuah hasil karya, buku, film, produk teknologi, dan lain-lain. Resensi juga dapat didefinisikan sebagai tulisan yang berisi pertimbangan buku, pembicaraan buku, atau ulasan buku dengan bahasa yang agak mentereng, membedah, menganalisis, dan mencari inti buku tersebut (Rahayu, 2007:151). Jadi dapat disimpulkan resensi buku merupakan jenis tulisan yang berisi tentang pertimbangan baik dan buruknya suatu produk atau karya.

Subbahasan lain dalam keterampilan menulis akademik adalah ringkasan/rangkuman buku. Asmi dikutip Alex (2011:124) menyatakan bahwa ringkasan adalah penyajian singkat dari suatu karangan asli dengan tetap membandingkan bagian atau bab dari karangan asli secara proporsional dalam 
bentuk yang singkat. Meringkas merupakan suatu keterampilan menulis yang berupaya utuk mengadakan reproduksi dari hasil karya yang telah ada. Ringkasan juga merupakan cara yang lebih efektif untuk menyajikan suatu karangan yang panjang ke dalam bentuk yang singkat.

Beberapa langkah dalam membuat ringkasan adalah (1) membaca naskah asli, (2) mencatat gagasan utama, (3) mengadakan reproduksi, dan (4) menuliskan ketentuan tambahan. Langkah-langkah tersebut merupakan cara untuk mempermudah menulis ringkasan. Melalui ringkasan juga seseorang dapat mengembangkan ekspresi serta penghematan kata. Dengan menulis ringkasan secara intensif dan terus-menerus akan mengembangkan daya kreasi dan konsentrasi, serta mempertajam pemahaman karya asli sehingga ringkasan tersebut seolah-olah hasil pematangan dari diri penulis sendiri.

\section{Membaca untuk Menulis}

Membaca merupakan satu dari empat keterampilan berbahasa. Tingkatan membaca dapat dibedakan menjadi dua macam yaitu membaca permulaan dan membaca pemahaman (reading comprehension). Menurut Anderson dikutip Alex (2011:74) membaca merupakan proses untuk memahami yang tersirat dalam tersurat, melihat pikiran yang terkandung di dalam kata-kata yang tertulis. Adapun menurut Wahyuni dan Ibrahim (2012:33) membaca pada hakikatnya merupakan suatu proses yang meliputi proses fisik dan psikologis. Proses tersebut mencakup pengamatan simbol-simbol tulisan, menginterpretasi yang diamati, mengikuti urutan kata, menghubungkan kata-kata, membuat inferensi dan evaluasi, membangun asosiasi, dan menyikapi secara personal kegiatan membaca.

Membaca merupakan kegiatan yang sangat kompleks. Artinya proses membaca tidak hanya sekadar melafalkan tulisan, tetapi melibatkan hal. Beberapa hal yang terlibat dalam proses membaca antara lain aktivitas visual, berpikir, psikolinguistik, dan metakognitif (Mountain dikutip Rahim, 2008:2-3).

Menurut Grabe dikutip Subadiyono (2011:27) membaca adalah proses interaktif. Artinya membaca merupakan proses memadukan informasi tekstual dengan informasi yang dibawa pembaca terhadap teks yang dibacanya. Proses 
membaca tidak hanya aktivitas mencari informasi dari teks tetapi juga merupakan pengaktifan sejumlah pengetahuan yang dimiliki oleh pembaca sehingga terjadi interaksi antara pembaca dengan teks.

Ada beberapa tujuan membaca yang dikemukakan oleh para ahli. Salah satunya dikemukakan oleh Anderson dikutip Alex (2011:75-76) sebagai berikut.

1. Membaca bertujuan untuk menemukan atau mengetahui penemuanpenemuan yang telah dilakukan oleh sang tokoh. Membaca seperti ini disebut membaca untuk memperoleh perincian dan fakta-fakta (reading for details or facts).

2. Membaca bertujuan untuk mengetahui topik utama yang baik dan menarik untuk dibaca (reading for main ideas).

3. Membaca untuk menemukan atau mengetahui apa yang terjadi pada setiap bagian cerita dan untuk mengetahui urutan atau susunan organisasi cerita (reading for sequence or organization).

4. Membaca untuk menemukan dan mengetahui apa yang dirasakan oleh para tokoh. Membaca ini sama seperti membaca untuk menyimpulkan atau membaca inferensi (reading for inference).

5. Membaca untuk menemukan dan mengetahui apa-apa yang tidak biasa, tidak wajar, dan kebenaran tentang sebuah cerita. Membaca ini biasa disebut sebagai membaca untuk mengklasifikasikan (reading to classify).

6. Membaca untuk menemukan apakah sang tokoh berhasil atau hidup dengan ukuran-ukuran tertentu dan apakah kita ingin berbuat seperti yang diperbuat oleh sang tokoh. Membaca ini disebut juga membaca untuk menilai atau membaca untuk mengevaluasi (reading to evaluate).

7. Membaca untuk menemukan bagaimana caranya sang tokoh berubah dan bagaimana hidupnya berbeda dari kehidupan yang kita kenal. Membaca ini bertujuan untuk membandingkan atau mempertentangkan (reading to compare or contrast).

Membaca untuk menulis ini dapat dikatakan sebagai membaca akademik. Membaca akademik mencakup membaca teks yang dipublikasikan dalam jurnal profesinal, antologi, monograf, dan prosiding (Subadiyono, 2011:48). Sesuai Surat 
keputusan DIKTI nomor 43 tahun 2006, membaca akademik ini mencakup membaca kritis artikel atau buku ilmiah, membaca kritis tulisan/artikel populer, dan penelusuran (pencarian) informasi melalui internet.

Membaca dapat dilakukan dari berbagai sumber salah satunya dari media internet. Internet merupakan jaringan komputer global yang terbentuk dari jaringanjaringan komputer lokal dan regional yang memungkinkan terjadinya komunikasi data antarkomputer. Internet menyediakan banyak situs untuk dikunjungi oleh mahasiswa dalam rangka mencari referensi. Situs menyediakan segala macam informasi dalam segala bidang termasuk hasil penelitian yang disajikan dalam bentuk jurnal.

Proses membaca untuk kegiatan menulis tidak hanya dilakukan dari sumber internet. Sumber-sumber lain yang dapat dijadikan referensi antara lain dari artikel/tulisan ilmiah dan membaca tulisan populer. Tulisan ilmiah dapat berupa tesis atau skripsi yang biasanya berisi informasi hasil penelitian yang mempunyai tesis (pernyataan umum) tentang masalah yang dibahas. Tulisan populer biasanya berisi tentang isu-isu yang berkaitan dengan masalah sosial yang sedang diminati masyarakat saat ini.

Ada beberapa perbedaan antara tulisan ilmiah dan tulisan populer. Perbedaanya dapat dilihat dari judul, teknik penulisan, validitas, tujuan penulisan, dan bahasa penulisan. Tulisan populer biasanya dimuat di majalah atau surat kabar yang menjadi wahana untuk mengkomunikasikan tentang sejarah, penemuan, teknologi, penemuan baru, aplikasi, atau juga isu-isu kontroversi iptek kepada masyarakat awam agar mereka dapat mengikuti perkembangan iptek tersebut.

Karakteristik tulisan populer tentu berbeda dengan tulisan ilmiah. Dari segi segmen yang dituju, tulisan ilmiah dibaca oleh kelompok profesional atau spesialis dalam suatu disiplin ilmu, maka pembaca tulisan populer berasal dari masyarakat awam, umum, atau profesional dalam bidang lain. Dari segi identitas penulis, tulisan ilmiah mencantumkan nama, lembaga akademik tempat ia bekerja serta kualifikasi akademiknya, maka penulis populer hanya menuliskan nama tanpa informasi lainnya. 
Dalam hal gaya penulisan karangan, tulisan ilmiah dan tulisan populer juga berbeda. Pada tulisan populer memuat bagian pendahuluan yang kreatif, yang mampu menarik minat pembaca, serta mendorong pembaca untuk membaca bagian-bagian berikutnya. Bagian-bagian selanjutnya dalam tulisan populer lebih banyak memuat kalimat-kalimat utama yang menjadi "point of interest" bagi pembaca.

\section{Berbicara Akademik}

Berbicara akademik merupakan bagian dari public speaking (berbicara di depan publik). Kemampuan berbicara khususnya berbicara akademik sangat menentukan dalam proses pembelajaran. Sebuah mata pelajaran yang dianggap momok bagi banyak orang akan semakin susah dipahami jika dibawakan oleh seorang pendidik yang mempunyai kemampuan komunikasinya rendah (Sirait, 2012: viii).

Berbicara akademik (berbicara ilmiah) tentu berbeda dengan berbicara pada saat santai. Berbicara akademik memerlukan kemampuan khusus baik secara penyajian, maupun pengungkapan melalui bahasa (diksi, gaya bahasa, gaya penyampaian, mimik, dan juga gestur).

Alex (2011:31) menyatakan bahwa berbicara akademik ialah berbicara dalam lingkungan akademik atau lembaga pendidikan berlandaskan pada hal-hal yang bersifat ilmiah atau ilmu pengetahuan. Jadi dapat disimpulkan dari beberapa pendapat di atas bahwa berbicara akademik merupakan kemampuan dalam berbahasa dalam situasi resmi atau formal untuk menyampaikan ide-ide atau hasil penelitian.

Kemampuan berbicara merupakan kemampuan praktik. Artinya, semakin banyak dan intensif manusia melakukan kebiasaan dan mengikuti forum-forum ilmiah tentu lambat laun mereka juga akan dapat melakukannya. Ada beberapa kriteria yang diperlukan untuk menjadi pembicara yang baik, di antaranya: (1) berbicara dengan gaya bicara sendiri, (2) mampu mengemas sesuatu yang sederhana dengan sudut pandang baru, (3) berbicara apa adanya, (4) tidak berbicara diri sendiri secara berlebihan, (5) mampu memulai dengan baik, (6) didukung suara 
yang meyakinkan, (7) menunjukkan empati, (8) memiliki selera humor, (9) memiliki antusias terhadap hal yang dibicarakan, (10) mampu mengatasi demam panggung (Pamungkas, 2012:42-44).

Kemampuan berbicara juga harus diimbangi dengan etika. Etika merupakan ketentuan-ketentuan (norma-norma) dan nilai-nilai yang dapat digunakan dalam kehidupan sehari-hari. Menurut Rismawaty dikutip Pamungkas (2012:45-47), etika berbicara adalah sebagai berikut.

1. Seorang pembicara harus dalam kondisi yang sehat jasmani dan rohani

2. Suara pembicara harus dapat didengar

3. Menghindari pembicaraan yang tidak berguna

4. Menghindari pembicaraan yang tidak terkait dengan topik

5. Menghindari perdebatan dan saling membantah

6. Menyampaikan pengalaman dan ilmunya dengan tenang

7. Menghindari sikap memaksakan diri

8. Menghindari ghibah atau adu domba

9. Bersedia mendengarkan pendapat orang lain

10. Pembicara tidak memonopoli pembicaraan

11. Pembicara berusaha menghindari perkataan kotor

12. Seorang pembicara tidak memandang rendah lawan bicara.

Jenis-jenis berbicara akademik mencakup berbicara untuk presentasi, seminar, dan berpidato dalam situasi formal. Berbicara untuk presentasi digunakan untuk menyampaikan pesan, ide, atau informasi kepada pendengar yang biasanya dibantu dengan alat visual berupa $L C D$ projector, sedangkan berbicara untuk keperluan seminar merupakan bentuk wicara yang melibatkan banyak pendengar dalam suatu forum. 


\section{METODE PENELITIAN}

\section{A. Metodologi Penelitian}

Penelitian ini merupakan penelitian pengembangan (Research and Development/R\&D). Penelitian pengembangan ini bertujuan untuk mengembangkan modul pembelajaran MPK bahasa Indonesia pada mahasiswa Fakultas Pertanian Universitas Muhammadiyah Palembang. Pengembangan modul yang dimaksudkan adalah bahan ajar berbentuk modul untuk pembelajaran di perguruan tinggi.

Adapun langkah-langkah pengembangan bahan ajar menurut Jolly dan Bolitho (dalam Tomlinson, 1998) adalah sebagai berikut.

1. Identifikasi kebutuhan

2. Eksplorasi kebutuhan materi

3. Realisasi kontekstual bahan ajar

4. Realisasi pedagogik

5. Produksi modul

6. Penggunaan modul oleh peserta didik

7. Evaluasi keefektifan modul

Berikut ini dijabarkan secara rinci langkah-langkah pengembangan bahan ajar yang mengadaptasi model Jolly dan Bolitho dengan menambahkan beberapa langkah pengembangan.

1. Identifikasi kebutuhan bahan ajar sebagai studi awal.

Langkah pertama yang harus dilakukan adalah identifikasi kebutuhan dengan menggunakan angket yang diajukan kepada dosen dan mahasiswa. Analisis ini digunakan untuk mengetahui apakah produk yang akan dikembangkan merupakan hal yang penting dalam suatu proses pembelajaran. Identifikasi kebutuhan ini berkaitan dengan kendala-kendala yang dihadapi dosen dan mahasiswa dalam pembelajaran MPK bahasa Indonesia, kesulitan-kesulitan mereka dalam menggunakan bahan ajar yang sudah ada, dan harapan-harapan dosen dan mahasiswa terhadap bahan ajar yang akan dikembangkan. Analisis kebutuhan ini dapat diketahui melalui angket dan wawancara. 
2. Eksplorasi kebutuhan materi.

Dalam penelitian pengembangan ini, eksplorasi kebutuhan materi merujuk pada silabus matakuliah bahasa Indonesia di Fakultas Pertanian Universitas Muhammadiyah Palembang dan SK DIKTI nomor 43 tahun 2006.

3. Realisasi kontekstual.

Dalam penelitian ini, kegiatan dalam modul ini antara lain dilengkapi dengan contoh-contoh yang disesuaikan dengan jurusan/fakultas pengguna modul. Artinya, dalam penjabaran beberapa materi yang membutuhkan ilustrasi atau contoh dapat dikembangkan dengan memilih topik atau tema pertanian dan topik-topik lainnya yang sedang jadi perbincangan.

4. Realisasi pedagogis.

Pada tahap ini, peneliti mencari bentuk-bentuk tugas dan latihan yang disesuaikan. Artinya pada tahap ini tugas dan latihan pada bahan ajar diharapkan akan menumbuhkan umpan balik penguasaan mahasiswa terhadap bahan ajar hasil pengembangan.

5. Produksi modul.

Pada tahap ini, peneliti memproduksi modul yang masih berupa prototipe awal. Hal-hal yang perlu diperhatikan dalam langkah ini termasuk menentukan desain produk bahan ajar serta menyiapkan sarana dan prasarana untuk uji coba dan validasi. Uji validasi tersebut mencakup ahli dalam bidang kegrafikaan, ahli pembelajaran, ahli bahasa, dan ahli penyajian.

6. Validasi ahli.

Proses validasi dilakukan untuk memperolah informasi, kritik, saran, dan masukan dari para ahli. Informasi dari validasi digunakan untuk meningkatkan kualitas bahan ajar yang dikembangkan. Tahap ini dilakukan sebelum bahan ajar diuji cobakan kepada mahasiswa. Validasi ahli meliputi 4 aspek yaitu: (1) kelayakan isi, (2) kebahasaan, (3) penyajian, dan (4) kegrafikaan. Hasil laporan validasi ahli dijadikan sebagai bahan revisi bahan ajar. 
7. Revisi modul berdasarkan hasil validasi.

Tahap ini dilakukan setelah mendapat masukan dan saran dari beberapa ahli validasi. Pada tahap ini, peneliti merevisi materi bahan ajar pengembangan berdasarkan informasi, saran, dan masukan dari para ahli. Revisi mencakup isi bahan ajar, kebahasaan, penyajian, dan kegrafikaan.

8. Penggunaan modul.

Tahap ini merupakan uji coba terhadap mahasiswa satu kelas (Agro A). Uji coba ini dilakukan terhadap 37 mahasiswa (satu kelas) dengan menerapkan pre-experiment design dengan jenis one group pretest-posttest design. Jenis ini digunakan dengan tujuan untuk memperoleh informasi tentang efek potensial modul yang dikembangkan. Pada tahap ini juga mahasiswa diberikan prates untuk mengetahui kemampuan awal sebelum diberikan perlakuan.

9. Evaluasi keefektifan modul.

Evaluasi ini merupakan evaluasi terhadap pemahaman siswa sebelum dan sesudah menggunakan bahan ajar hasil pengembangan. Evaluasi ini dilakukan dengan cara membandingkan hasil tes pemahaman dan kemampuan mahasiswa dalam berbahasa sebelum dan sesudah menggunakan bahan ajar.

Langkah-langkah pengembangan penelitian ini sebagai berikut.

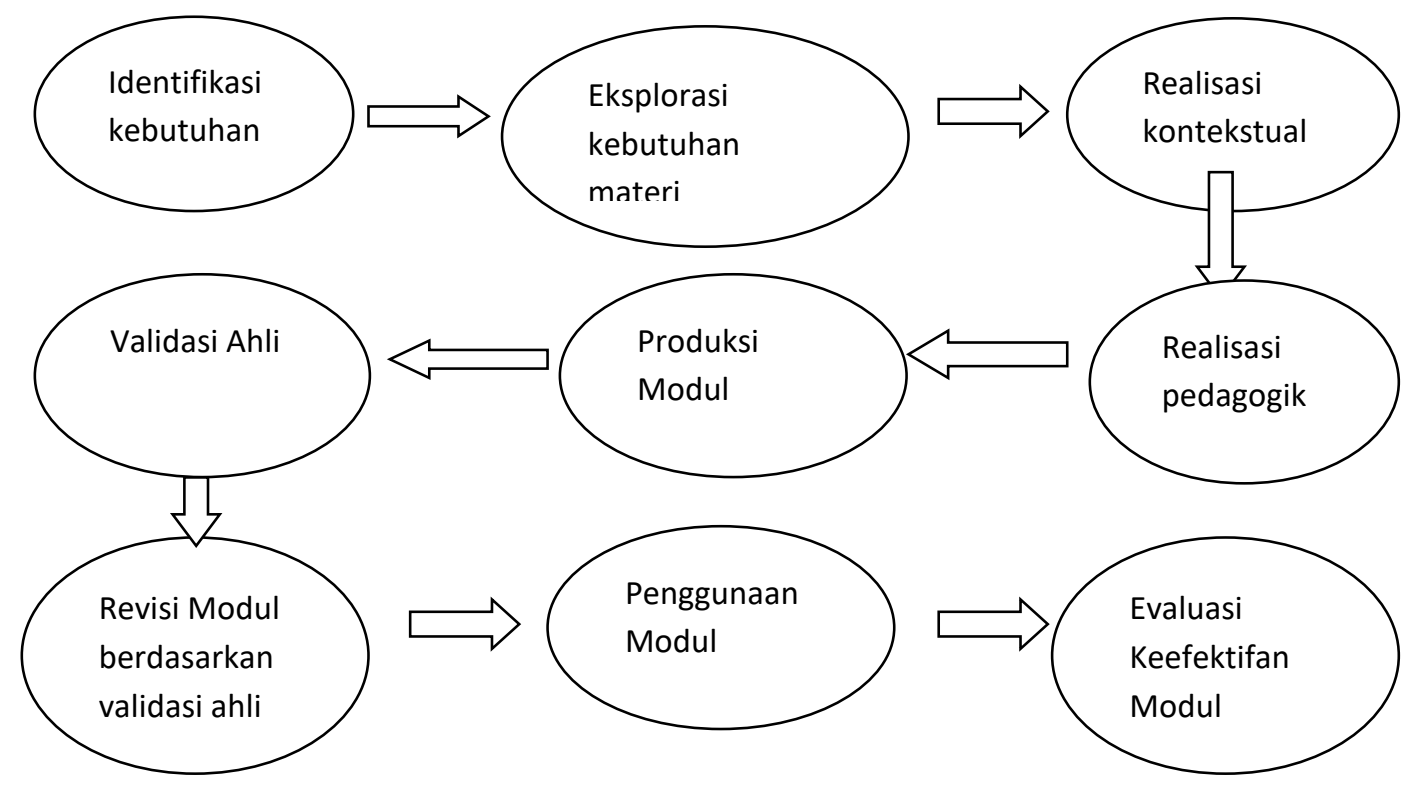




\section{B. Lokasi dan Subjek Penelitian}

Penelitian ini dilaksanakan di Fakultas Pertanian Universitas Muhammadiyah Jalan A. Yani Plaju, Palembang. Subjek penelitian ini adalah mahasiswa semester III Fakultas Pertanian Universitas Muhammadiyah Palembang sebanyak 37 mahasiswa. Penentuan mahasiswa yang dijadikan subjek dalam penelitian dan pengembangan ini menggunakan teknik Purposive. Teknik ini digunakan dengan mempertimbangkan keanekaragaman prestasi belajar mahasiswa baik tinggi, sedang, maupun rendah.

Dosen yang menjadi subjek penelitian ini adalah dosen yang mengajar MPK bahasa Indonesia di Universitas Muhammadiyah Palembang sebanyak 3 orang. Sementara dalam proses validasi bahan ajar hasil pengembangan ini adalah 4 orang yang mencakup berbagai bidang keahlian, seperti ahli bahan ajar, ahli kebahasaan, ahli kegrafikaan, dan ahli penyajian.

\section{Teknik Pengumpulan Data}

\section{Angket}

Angket yang digunakan untuk penelitian ini adalah angket terbuka. Angket terbuka adalah angket yang diberikan kepada mahasiswa dan dosen MPK bahasa Indonesia yang bertujuan untuk memberikan kesempatan bagi mereka untuk menjawab dengan kalimatnya sendiri (uraian). Angket tersebut diberikan kepada 55 mahasiswa (dua kelas) dan 3 dosen dengan tujuan untuk mendapatkan informasi yang berhubungan dengan keinginan dan semua kendala yang dihadapi mahasiswa dalam pembelajaran MPK bahasa Indonesia. Selain itu, angket juga dimaksudkan untuk memperoleh informasi tentang kekurangan dan kelebihan pada bahan ajar sebelumnya. Melalui angket ini juga dapat digali informasi tentang masukanmasukan atau input sebagai bahan pertimbangan dalam menyusun bahan ajar MPK bahasa Indonesia termasuk juga subbahasan yang perlu ditambahkan atau dihilangkan dari bahan ajar sebelumnya.

Informasi tentang kualitas bahan ajar yang akan dikembangkan juga dapat diperoleh melalui angket. Angket tersebut diberikan kepada para pakar/ahli untuk memperoleh informasi tentang kualitas bahan ajar tersebut. Kualitas suatu bahan 
ajar dapat ditinjau dari beberapa komponen penilaian. Komponen-kompenen tersebut mencakup beberapa aspek, yaitu kecermatan isi, ketepatan cakupan, ketercernaan bahan ajar, penggunaan bahasa, kemasan, ilustrasi, dan kelengkapan komponen (Setiawan, 2007:1.40-1.57).

Tahap validasi ahli pada penelitian pengembangan ini meliputi, (1) ahli penyajian, (2) ahli bahasa, (3) ahli kelayakan isi, dan (4) ahli kegrafikaan. Untuk memperoleh informasi tentang kualitas modul tersebut digunakan angket yang diberikan kepada pakar/ahli.

\section{Wawancara}

Selain angket, peneliti juga menggunakan teknik wawancara. Wawancara ini digunakan sebagai teknik pelengkap angket. Wawancara ini diperlukan jika ada informasi yang kurang jelas dari beberapa pertanyaan dalam angket tersebut. Beberapa hal yang menjadi fokus dalam wawancara tersebut antara lain tentang harapan-harapan tentang suatu bahan ajar, kesulitan-kesulitan dalam pembelajaran MPK bahasa Indonesia, dan hal-hal yang berhubungan dengan kekurangan dan kelebihan yang terdapat pada bahan ajar yang sudah ada.

\section{Tes}

Untuk mendapatkan informasi tentang keefektifan modul yang dikembangkan, peneliti melakukan tes kepada mahasiswa. Tes ini diberikan kepada kelas Agro A yang menjadi subjek penelitian baik prates (sebelum menggunakan modul) maupun pascates (sesudah menggunakan modul). Bentuk tes yang digunakan adalah berupa tes tertulis (tes pilihan ganda) dan tes unjuk kerja (performance). Dengan menggunakan tes ini diharapkan dapat diketahui efek potensial hasil belajar mahasiswa yang menggunakan modul tersebut.

Tes tertulis pilihan ganda merupakan tes yang ditujukan kepada mahasiswa yang berisi materi tentang pengetahuan umum. Materi tersebut mencakup (1) sejarah, kedudukan, dan fungsi bahasa Indonesia, (2) makalah, (3) paragraf, (4) kutipan dan daftar pustaka, dan (5) wacana. Pada tes ini menggunakan rumus sederhana berikut. 


$$
\text { Skor }=\frac{\text { skor yang diperoleh }}{\text { Skor Maksimum(25) }} \times 100
$$

Pada tes unjuk kerja (performance) dibagi menjadi menjadi 2 bagian. Pertama, tes unjuk kerja untuk menulis akademik yaitu menulis esai. Kedua, tes unjuk kerja berbicara yaitu tes berbicara dalam presentasi.

Untuk mengukur kemampuan mahasiswa menulis esai, peneliti menggunakan rubrik penilaian dengan beberapa indikator yang ada pada tabel 1 . Pada tes unjuk kerja berbicara, peneliti juga menggunakan sebuah rubrik penilaian. Secara jelasnya dapat dilihat pada tabel 2.

Tabel 1

Indikator Penilaian Menulis Esai

\begin{tabular}{|c|c|c|}
\hline No & Aspek Penilaian & $\begin{array}{l}\text { Nilai } \\
\text { maksimum }\end{array}$ \\
\hline 1. & $\begin{array}{l}\text { Format (letak judul di tengah, baris pertama tiap } \\
\text { paragraf menjorok ke dalam, margin kiri dan kanan, } \\
\text { dan penggunaan } 2 \text { spasi) }\end{array}$ & 5 \\
\hline 2. & $\begin{array}{l}\text { Mekanik } \\
\text { a. Tanda baca: tanda titik, koma, titik koma, dan } \\
\text { tanda kutip ( } 3 \text { ) } \\
\text { b. Huruf kapital (1) } \\
\text { c. Ejaan (1) }\end{array}$ & 5 \\
\hline 3. & $\begin{array}{l}\text { Isi } \\
\text { a. Esai memenuhi syarat yang ditentukan (5) } \\
\text { b. Esai menarik untuk dibaca (5) } \\
\text { c. Esai menunjukkan ide penulis dan kepeduliannya } \\
\quad(10)\end{array}$ & 20 \\
\hline 4. & $\begin{array}{l}\text { Pengorganisasian Esai } \\
\text { a. Memiliki paragraf pembuka, tubuh esai, dan } \\
\text { kesimpulan (5) } \\
\text { b. Paragraf pembuka: diakhiri dengan pernyataan } \\
\text { tesis (5) } \\
\text { c. Tubuh esai: } \\
\text { - Masing-masing pargraf membahas sebuah } \\
\text { topik dimulai dengan kalimat topik yang jelas } \\
\text { (5) } \\
\text { - Masing-masing paragraf memiliki materi } \\
\text { pendukung secara spesifik: fakta-fakta, } \\
\text { contoh-contoh, kutipan, dan lainnya (10) } \\
\text { - Masing-masing paragraf memiliki kesatuan } \\
\text { (5) } \\
\text { - Masing-masing paragraf koheren (5) }\end{array}$ & 45 \\
\hline
\end{tabular}




\begin{tabular}{|l|l|l|}
\hline & Transisi digunakan untuk menghubungkan & \\
& $\begin{array}{l}\text { antar paragraf (5) } \\
\text { d. Kesimpulan: kesimpulan diambil dari } \\
\text { memparafrasakan pernyataan tesis, meringkas } \\
\text { poin-poin penting, mengingatkan kembali } \\
\text { pembaca dengan pertanyaan yang berkaitan } \\
\text { dengan topik, dan lainnya (5) }\end{array}$ & \\
\hline 5. & Struktur kalimat dan tatabahasa (25) & 25 \\
\hline
\end{tabular}

(Oshima dan Ann Hogue, 2006:316)

Tabel 2

Indikator Rubrik Penilaian Berbicara

\begin{tabular}{|c|c|c|c|c|c|}
\hline No & Aspek yang dinilai & 1 & 2 & 3 & 4 \\
\hline 1. & Berdiri tegap & & & & \\
\hline 2. & Memandang ke arah hadirin & & & & \\
\hline 3. & Pelafalan & & & & \\
\hline 4. & Sistematika & & & & \\
\hline 5. & Mimik & & & & \\
\hline 6. & Intonasi & & & & \\
\hline 7. & Kejelasan gagasan & & & & \\
\hline \multicolumn{6}{|c|}{ Jumlah } \\
\hline & Skor maksimum & \multicolumn{4}{|c|}{28} \\
\hline
\end{tabular}

(Hamzah B. Uno dan Satria Koni, 2012:21)

Kriteria penskoran nomor 1 dan 2:

$1=$ bila tidak pernah melakukan

$2=$ bila jarang melakukan

3= bila kadang-kadang melakukan

4= bila selalu melakukan

Kriteria penskoran nomor 3 sampai dengan 7, semakin baik penampilan mahasiswa semakin tinggi skor yang diperoleh. 


\section{Teknik Analisis Data}

Data penelitian dianalisis secara kualitatif dan kuantitatif. Data angket dan wawancara dianalisis secara kualitatif sehingga jelas untuk dideskripsikan. Selanjutnya, data kuantitatif berupa hasil tes mahasiswa pada uji coba lapangan terbatas dianalisis dengan menggunakan uji t.

\section{a. Teknik Analisis Data Angket}

Data angket yang diberikan pada mahasiswa dan dosen diolah dan kemudian dideskripsikan. Hasil dari data ini diharapkan menjadi acuan dan landasan dalam mengembangkan bahan ajar Modul Bahasa Indonesia untuk Perguruan Tinggi. Pada hakikatnya, angket dari mahasiswa dan dosen diperiksa dan dianalisis secara seksama. Tahap berikutnya angket dideskripsikan dan selanjutnya disimpulkan.

Sementara itu, data hasil evaluasi (validasi modul) dari pakar atau ahli dianalisis seacra deskriptif dengan menggunakan skor. Skala pengukurannya menggunakan jenis rating scale:

$1=$ sangat tidak memadai

$2=$ kurang sesuai

$3=$ cukup

$4=$ baik

$5=$ sangat baik

(Sugiono, 2012:135)

Ada beberapa aspek yang dinilai dalam angket validasi, yaitu kelayakan isi, kebahasaan, sajian, dan kegrafikaan. Semua aspek itu dinilai oleh para pakar berdasarkan pada modul pengembangan yang dilakukan oleh peneliti.

Validasi kelayakan materi pada bahan ajar hasil pengembangan peneliti mencakup 5 komponen. Komponen-komponen tersebut adalah komponen kesesuaian dengan silabus, kesesuaian dengan perkembangan siswa, kesesuaian dengan kebutuhan bahan ajar, kebenaran substansi, dan manfaat bagi penambahan wawasan pengetahuan. Untuk kriteria penilaian dapat dilihat pada tabel 3 berikut. 
Tabel 3

Kriteria Penilaian Angket Validasi Kelayakan Materi

\begin{tabular}{|l|l|}
\hline \multicolumn{1}{|c|}{ Nilai } & \multicolumn{1}{c|}{ Predikat } \\
\hline $21-25$ & Sangat baik/sesuai \\
\hline $16-20$ & Baik \\
\hline $11-15$ & Cukup baik \\
\hline $6-10$ & Kurang baik \\
\hline$<5$ & Tidak baik/tidak sesuai \\
\hline
\end{tabular}

Pada validasi bahasa, ada 4 komponen bahan ajar yang nilai. Komponen tersebut meliputi (1) keterbacaan, (2) kejelasan, (3) kesesuaian dengan kaidah bahasa Indonesia, dan (4) penggunaan bahasa secara efektif. Kriteria penilaian tersebut dapat dilihat pada tabel 4 berikut.

Tabel 4

Kriteria Penilaian Angket Validasi Kebahasaan

\begin{tabular}{|l|l|}
\hline Nilai & Predikat \\
\hline $17-20$ & Sangat baik/sesuai \\
\hline $13-16$ & Baik \\
\hline $9-12$ & Cukup baik \\
\hline $5-8$ & Kurang baik \\
\hline$<4$ & Tidak baik/tidak sesuai \\
\hline
\end{tabular}

Validasi aspek sajian pada modul Bahasa Indonesia untuk Perguruan

Tinggi hasil pengembangan peneliti mencakup 5 komponen. Komponen-komponen tersebut terdiri atas (1) kejelasan tujuan, (2) urutan sajian, (3) pemberian motivasi dan daya tarik, (4) interaksi, dan (5) kelengkapan informasi. Kriteria tersebut dapat dilihat pada tabel 5 berikut. 
Tabel 5

Kriteria Penilaian Angket Validasi Sajian

\begin{tabular}{|l|l|}
\hline Nilai & Predikat \\
\hline $21-25$ & Sangat baik/sesuai \\
\hline $16-20$ & Baik \\
\hline $11-15$ & Cukup baik \\
\hline $6-10$ & Kurang baik \\
\hline$<5$ & Tidak baik/tidak sesuai \\
\hline \multicolumn{2}{|l|}{ Untuk validasi ahli kegrafikaan pada modul Bahasa Indonesia untuk }
\end{tabular}

Perguruan Tinggi hasil pengembangan peneliti, validator menilai 5 komponen. Kelima komponen tersebut adalah (1) penggunaan font: ukuran dan jenis huruf, (2) tata letak, (3) ketepatan ilustrasi gambar, (4) cover, dan (5) tampilan fisik. Kriteri penilaian tersebut dapat dilihat pada tabel 6 berikut.

Tabel 6

Kriteria Penilaian Angket Validasi Kegrafikaan

\begin{tabular}{|l|l|}
\hline Nilai & Predikat \\
\hline $21-25$ & Sangat baik/sesuai \\
\hline $16-20$ & Baik \\
\hline $11-15$ & Cukup baik \\
\hline $6-10$ & Kurang baik \\
\hline$<5$ & Tidak baik/tidak sesuai \\
\hline
\end{tabular}

\section{b. Teknik Analisis Data Tes}

Teknik tes yang digunakan dalam penelitian ini adalah tes sebelum (pretest) dan tes sesudah (posttest). Prates merupakan tes yang dilakukan pada mahasiswa sebelum menggunakan bahan ajar yang dikembangkan oleh peneliti. Pascates adalah tes yang dilakukan setelah siswa mempelajari materi-materi yang ada pada modul hasil pengembangan. 
Tes yang dilakukan dalam penelitian ini merupakan tes pilihan ganda dan tes unjuk kerja. Tes pilihan ganda merupakan tes dari beberapa materi dalam modul hasil pengembangan yang bersifat informasi atau menambah wawasan. Tes kedua merupakan tes unjuk kerja (performance) yang terdiri dari tes menulis esai dan tes berbicara dalam presentasi. Dalam tes menulis esai ini, mahasiswa diberikan pilihan tema yang bervariasi, yaitu pertanian dan kehutanan, teknologi, dan isu-isu terkini. Pada tes berbicara, mahasiswa mempresentasikan materi tentang pertanian dalam bentuk slide power point dan menyajikan di depan kelas.

Langkah-langkah dalam menganalisis data tes dalam penelitian ini adalah.

(1) Data skor tes dianalisis dengan melihat selisih antara skor hasil tes mahasiswa sebelum dan sesudah menggunakan bahan ajar

(2) Data tes diidentifikasi dan diklasifikasi berdasarkan komponen bahan ajar yang dikembangkan

(3) Data tes disajikan dalam bentuk tabel, grafik, dan kurva

(4) Data tes dianalisis secara deskriptif dalam bentuk perhitungan kuantitatif

(5) Data tes dianalisis dengan menggunakan uji t melaui SPSS 16

(6) Membuat simpulan terhadap hasil tes analisis data

Skor hasil dari masing-masing tes dianalisis dengan cara mengubah skor tersebut menjadi nilai. Nilai diperoleh dengan cara membagi skor yang diperoleh mahasiswa dengan skor maksimum dan dikalikan 100. Berdasarkan hasil perhitungan tersebut, diperoleh tingkat penguasaan yang diperoleh masing-masing mahasiswa. Untuk lebih jelasnya, dapat dilihat pada tabel 7 berikut.

Tabel 7

Kriteria Tingkat Penguasan Siswa

\begin{tabular}{|l|l|}
\hline $86-100$ & Sangat baik/sesuai \\
\hline $76-85$ & Baik \\
\hline $66-75$ & Cukup \\
\hline $56-65$ & Kurang sesuai \\
\hline$<55$ & Tidak baik/tidak sesuai \\
\hline
\end{tabular}


Setelah diketahui nilai masing-masing mahasiswa, selanjutnya peneliti menghitung nilai rata-rata seluruh subjek penelitian. Nilai rata-rata ini dipisah menjadi 2 bagian, yaitu nilai rata-rata sebelum menggunakan bahan ajar (pretest) dan nilai rata-rata setelah menggunakan bahan ajar (postest). Selanjutnya nilai ratarata tersebut dibandingkan antara nilai rata-rata prates dan pascates.

Tahap selanjutnya data dianalisis melalui uji-t satu sampel dengan menggunakan SPSS 16. Hal ini dilakukan untuk memperoleh efek potensial atau signifikasi perbedaan tingkat pemahaman mahasiswa sebelum dan sesudah menggunakan bahan ajar hasil pengembangan. Dari hasil tersebut dapat diketahui makna perbedaan hasil tes sebelum dan sesudah menggunakan bahan ajar hasil pengembangan peneliti.

\section{c. Teknik Analisis Data Wawancara}

Data hasil wawancara dari mahasiswa dan dosen digunakan untuk memperjelas data dari angket analisis kebutuhan. Data ini diolah secara objektif, dideskripsikan, dan selanjutnya ditarik simpulan. Hasil dari data wawancara ini sudah tentu digunakan untuk keperluan pengembangan bahan ajar supaya lebih berkualitas dari segi materi dan kesesuaian pada kebutuhannya.

\section{HASIL PENELITIAN DAN PEMBAHASAN}

\section{A. Hasil Penelitian}

Model pengembangan yang digunakan dalam penelitian ini adalah model Jolly dan Bollito. Model pengembangan tersebut mencakup beberapa tahapan atau langkah-langkah. Tahapan-tahapan tersebut adalah analisis kebutuhan, eksplorasi kebutuhan materi, realisasi kontekstual, realisasi pedagogik, produksi bahan ajar, uji coba modul, dan evaluasi bahan ajar.

Berikut ini diuraikan data hasil penelitian berdasarkan langkah-langkah pengembangan tersebut. 


\section{Analisis Kebutuhan}

\section{a. Analisis Kebutuhan Mahasiswa}

Dalam penelitian pengembangan modul MPK Bahasa Indonesia ini, ada beberapa landasan informasi yang digunakan untuk mengembangkannya. Landasan tersebut adalah (1) tanggapan mahasiswa terhadap bahan ajar yang digunakan sebelumnya, (2) kendala tau hambatan yang dihadapi mahasiswa dalam pembelajaran MPK Bahasa Indonesia, dan (3) harapan mahasiswa terhadap bahan ajar yaitu modul yang diperlukan dalam pembelajaran MPK Bahasa Indonesia, termasuk materi ajar, topik-topik yang diharapkan, bentuk evaluasi, dan penilaian.

Proses analisis kebutuhan dilakukan pada tanggal 20 Juni 2013. Peneliti memberikan kuesioner terhadap 55 orang mahasiswa Jurusan Agroteknologi semester II, Fakultas Pertanian Universitas Muhammadiyah Palembang. Kuesioner ini diberikan pada saat jam perkuliahan MPK Bahasa Indonesia.

Berdasarkan jawaban angket, diperoleh informasi tentang bahan ajar yang mereka harapkan. Harapan para mahasiswa sebanyak 55 orang (100\%) adalah perlunya bahan ajar berupa modul yang dikembangkan dalam membantu proses belajar mengajar di kelas.

Substansi materi yang diharapkan oleh mahasiswa merupakan materi-materi yang ada dalam SK DIKTI Nomor 43 tahun 2006 yang dikombinasikan dengan silabus matakuliah Bahasa Indonesia di Fakultas Pertanian Universitas Muhammadiyah Palembang yang sudah ada. Substansi materi dari SK DIKTI tersebut meliputi sejarah, kedudukan dan fungsi bahasa Indonesia, menulis akademik, membaca untuk menulis, dan berbicara akademik. Substansi materi dari silabus Universitas Muhammadiyah Palembang mencakup sejarah bahasa Indonesia, ejaan yang disempurnakan, kalimat efektif, kesalahan berbahasa, pengembangan paragraf, menulis esai, kerangka karangan, wacana, kutipan, daftar pustaka, surat-menyurat, dan makalah ilmiah.

Dari kedua sumber tersebut, diperoleh informasi materi yang diharapkan oleh mahasiswa dalam pengembangan bahan ajar ini. Materi-materi yang mereka pilih dapat dilihat pada tabel berikut. 
Tabel 8

Tabel Rekapitulasi Kebutuhan Materi mahasiswa

\begin{tabular}{|l|l|l|l|}
\hline No & Materi yang Diharapkan & $\begin{array}{l}\text { Jumlah } \\
\text { Mahasiswa }\end{array}$ & $\begin{array}{l}\text { Persentase } \\
(\%)\end{array}$ \\
\hline 1. & $\begin{array}{l}\text { Sejarah, Kedudukan, dan Fungsi } \\
\text { Bahasa Indonesia }\end{array}$ & 50 & $91 \%$ \\
\hline 2. & Menulis Paragraf & 48 & $87 \%$ \\
\hline 3. & Menulis Esai & 47 & $85 \%$ \\
\hline 4. & Makalah ilmiah & 30 & $54 \%$ \\
\hline 5. & Kutipan dan Daftar Pustaka & 45 & $82 \%$ \\
\hline 6. & Wacana & 40 & $73 \%$ \\
\hline 7. & Berbicara untuk Presentasi & 40 & $73 \%$ \\
\hline 8. & Berbicara untuk Seminar & 35 & $64 \%$ \\
\hline 9. & Berbicara dalam Forum Formal & 37 & $67 \%$ \\
\hline & & & \\
\hline
\end{tabular}

Informasi pendukung materi (contoh atau topik bahasan) yang diharapkan oleh mahasiswa seharusnya sesuai atau berkaitan dengan bidang studi atau jurusan yang mereka pilih. Topik tentang Pertanian dan Kehutanan dipilih oleh subjek penelitian sebanyak 55 mahasiwa (100\%). Topik lainnya yang diharapkan adalah Teknologi, yaitu sebanyak 42 (76\%) subjek penelitian. Topik tentang Kesehatan juga dipilih oleh subjek penelitian sebanyak 38 (69\%). Sebagian di antaranya juga mengharapkan informasi pendukung dalam modul tersebut dipilih dari topik-topik umum yang sedang berkembang di masyarakat, yaitu sebesar 40 (73\%) mahasiswa.

Berdasarkan bahasa yang digunakan dalam bahan ajar, subjek penelitian memberikan saran-saran yang bervariatif. Sebanyak 37 (67\%) subjek penelitian mengharapkan bahasa yang baku dan sesuai dengan Ejaan Yang Disempurnakan. Hal lainnya adalah penggunanan istilah-istilah yang belum familiar (umum). Sebanyak 40 (73\%) subjek penelitian menyarankan untuk menggunakan istilahistilah yang sudah mereka pahami. Namun demikian, di antara subjek penelitian mengharapkan agar bahasa yang digunakan dalam modul ini harus mudah dimengerti, yaitu sebesar $48(87 \%)$.

Berkaitan dengan latihan, subjek penelitian mengharapkan adanya bentuk latihan yang dapat meningkatkan kemampuan mereka dalam memahami materi modul tersebut. Jika materi tersebut lebih mengedepankan pengetahuan semata, 
subjek penelitian mengharapkan bentuk latihannya berupa latihan menjawab pertanyaan-pertanyaan atau tes pilihan ganda. Materi modul yang bersifat unjuk kerja, bentuk latihan yang diharapkan oleh subjek penelitian adalah tes performansi/unjuk kerja.

Bentuk tes formatif yang diharapkan subjek penelitian adalah tes pilihan ganda. Bentuk ini banyak dipilih oleh subjek penelitian karena dianggap lebih kompak dan sederhana bila dibandingkan bentuk tes yang lain. Subjek penelitian beralasan bahwa bentuk tes formatif ini mampu mengukur kemampuan yang yang bersifat pengetahuan maupun kemampuan lainnya. Bentuk tes ini dipilih sebanyak 51 (93\%) subjek penelitian.

Dalam hal perwajahan (sampul, warna, dan contoh-contoh), subjek penelitian mengharapkan adanya bahan ajar yang memiliki daya tarik tersendiri. Kesimpulan dari aspek ini adalah sampul modul diharapkan tidak terlalu menyolok dan terkesan penuh dengan foto-foto atau gambar-gambar. Bagian-bagian yang penting dalam modul, seperti tujuan, contoh-contoh, dan rangkuman diharapkan berbeda dengan bagian yang lain. Hal ini bertujuan untuk memudahkan bagi subjek penelitian dalam mempelajari modul tersebut.

Ada beberapa saran yang diberikan oleh subjek penelitian terhadap pengembangan bahan ajar Matakuliah Pengembangan Kepribadian (MPK) Bahasa Indonesia ini. Saran-saran tersebut lebih bersifat umum, antara lain: (1) penggunaan bahasa yang mudah dipahami, (2) bentuk atau penampilan modul yang lebih menarik dari buku ajar yang sudah ada, dan (3) penggunaan bahasa dan istilah yang tidak terlalu sukar dipahami. Semua saran dari subjek penelitian ini secara umum dapat diklasifikasikan menjadi dua bagian, yaitu (1) saran-saran yang berhubungan dengan perwajahan (sampul) dan (2) saran-saran yang berhubungan bahasa yang digunakan dalam modul.

Secara lebih jelas, analisis kebutuhan mahasiswa tersebut dijabarkan pada tabel berikut ini. 
Tabel 9

Kebutuhan Mahasiswa

\begin{tabular}{|c|c|c|c|}
\hline No & Aspek yang dibutuhkan & $\begin{array}{l}\text { Jumlah } \\
\text { Mahasiswa }\end{array}$ & $\begin{array}{l}\text { Persentase } \\
(\%)\end{array}$ \\
\hline 1. & $\begin{array}{l}\text { Perlunya bahan ajar pada matakuliah MPK } \\
\text { bahasa Indonesia }\end{array}$ & 55 & $100 \%$ \\
\hline \multirow[t]{10}{*}{2.} & Segi isi/materi: & & \\
\hline & $\begin{array}{l}\text { d. Sejarah, Kedudukan, dan Fungsi Bahasa } \\
\text { Indonesia }\end{array}$ & 50 & $91 \%$ \\
\hline & e. Menulis paragraf & 48 & $87 \%$ \\
\hline & f. Menulis Esai & 47 & $85 \%$ \\
\hline & g. Makalah Ilmiah & 30 & $54 \%$ \\
\hline & h. Kutipan dan Daftar Pustaka & 45 & $82 \%$ \\
\hline & i. Wacana & 40 & $73 \%$ \\
\hline & j. Berbicara untuk Presentasi & 40 & $73 \%$ \\
\hline & k. Berbicara untuk Seminar & 35 & $64 \%$ \\
\hline & 1. Berbicara untuk Forum Formal & 37 & $67 \%$ \\
\hline \multirow[t]{5}{*}{3.} & Topik-topik/tema Pelengkap Materi & & \\
\hline & a. Pertanian dan Kehutanan & 55 & $100 \%$ \\
\hline & b. Teknologi & 42 & $76 \%$ \\
\hline & c. Kesehatan & 34 & $69 \%$ \\
\hline & d. Isu-isu terkini & 40 & $73 \%$ \\
\hline \multirow[t]{4}{*}{4.} & Berkaitan dengan bahasa modul & & \\
\hline & a. Sesuai dengan EYD & 38 & $69 \%$ \\
\hline & b. Menggunakan istilah-istilah umum & 35 & $64 \%$ \\
\hline & $\begin{array}{l}\text { Menggunakan bahasa yang mudah } \\
\text { dimengerti }\end{array}$ & 37 & $67 \%$ \\
\hline 5. & Bentuk Tes Formatif berupa pilihan ganda & 55 & $100 \%$ \\
\hline 6. & $\begin{array}{l}\text { Cover atau sampul yang menarik dan tidak } \\
\text { menyolok }\end{array}$ & 40 & $73 \%$ \\
\hline
\end{tabular}

\section{b. Analisis Kebutuhan Dosen}

Analisis kebutuhan tidak hanya dilakukan kepada mahasiswa, tetapi juga terhadap beberapa dosen. Dosen yang dijadikan subjek penelitian ini merupakan dosen yang mengampu matakuliah bahasa Indonesia untuk jurusan nonbahasa di lingkungan Universitas Muhammadiyah Palembang.

Hasil analisis kebutuhan dosen terhadap pengembangan modul bahasa Indonesia di Fakultas Pertanian Universitas Muhammadiyah Palembang menunjukkan adanya kebutuhan yang relatif sama. Informasi tentang kebutuhan 
dosen tersebut diperoleh melalui angket terbuka dan wawancara yang diberikan kepada dosen-dosen bahasa Indonesia di Universitas Muhammadiyah Palembang. Sebelum para dosen mengisi angket tersebut, peneliti memberikan beberapa instruksi dan gambaran-gambaran yang terdapat dalam angket.

Informasi kebutuhan dosen yang diidentifikasi tersebut berkaitan dengan beberapa hal, yaitu (1) harapan dan keinginan dosen terhadap bahan ajar yang meliputi kebutuhan materi yang diinginkan, struktur dan bentuk penyajian materi, bahasa yang digunakan, bentuk latihan dan tes formatif, serta perwajahan; (2) kesulitan atau hambatan yang dialami oleh mahasiswa dan beberapa penyebabnya; (3) tanggapan terhadap penggunaan bahan ajar yang sudah ada; dan (4) saran-saran terhadap pengembangan bahan ajar.

Hasil analisis terhadap kebutuhan dosen ini menunjukkan bahwa subjek penelitian menganggap perlunya modul MPK bahasa Indonesia diberikan kepada mahasiswa, khususnya mahasiswa Fakultas Pertanian Universitas Muhammadiyah Palembang. Pembelajaran matakuliah ini diharapkan dapat menambah wawasan bagi para mahasiswa dan tentunya mampu mengaplikasikan berbagai keterampilan dalam berbahasa Indonesia. Oleh karena itu, bahan ajar yang digunakan dalam pembelajaran ini disesuaikan dengan keinginan dan aspek manfaatnya bagi para mahasiswa.

Informasi tentang manfaat dan tujuan yang diharapkan oleh para subjek penelitian adalah (1) bersifat kontekstual, (2) informasi terbaru dan akurat, (3) bersifat produktif. Tujuan dan manfaat yang bersifat kontekstual adalah sistim pembelajaran yang berhubungan dengan konteksnya, dalam hal ini yang berhubungan dengan lingkungan mahasiswa. Tujuan informasi terbaru dan akurat merupakan pembelajaran yang diarahkan pada aturan-aturan yang berlaku dan terbaru. Tujuan produktif merupakan pembelajaran dengan bahan ajar yang memberi langkah-langkah praktis dalam beberapa keterampilan yang diharapkan.

Informasi materi yang diharapkan subjek penelitian dalam modul MPK bahasa Indonesia ini dapat dikategorikan menjadi 3 bagian, yaitu materi bersifat teknis/praktis, contoh-contoh yang berhubungan dengan materi, dan materi yang bersifat produktif. Materi yang bersifat teknis mencakup cara-cara dalam menulis 
atau berbicara. Contoh-contoh yang berhubungan dengan materi pada modul MPK bahasa Indonesia ini lebih spesifik ke topik dan tema yang sesuai dengan jurusan dan kemampuan mahasiswanya. Materi yang bersifat produktif yaitu materi yang mampu menggiring mahasiswa menghasilkan karya (unjuk kerja).

Sehubungan penyajian materi yang diharapkan subjek penelitian dalam pembelajaran ini ada dua jenis, yaitu strategi deduktif dan strategi induktif. Strategi deduktif adalah strategi yang diawali dengan memberikan uraian dan penjelasan materi kepada mahasiswa terlebih dahulu dari dosen kemudian diikuti dengan latihan sesuai dengan keterampilan yang ditentukan dalam modul MPK ini. Strategi induktif merupakan strategi yang dimulai dengan kegiatan siswa membaca materi atau mempelajari contoh-contoh kemudian diikuti dengan penjelasan dosen tentang materi yang berkaitan dengan tujuan yang ditetapkan.

Berdasarkan aspek kebahasaan yang digunakan dalam bahan ajar, semua subjek penelitian menginginkan bahasa yang sesuai kaidah bahasa Indonesia yang baik dan benar. Subjek penelitian mengharapkan bahwa bahan ajar hendaklah memperhatikan penggunaan ejaan, tanda baca, dan pilihan bahasa yang disesuaikan dengan kemampuan mahasiswa.

Berdasarkan jawaban yang diberikan subjek penelitian tentang bentuk latihan dan tes formatif dalam bahan ajar lebih variatif. Keragaman tes ini diperlukan dalam mengakomodasi semua keterampilan yang diharapkan dalam modul ini. Bentuk-betuk latihan dan tes tersebut adalah tes uraian, tes performansi, dan tes pilihan ganda. Bagian latihan pada modul ini menggunakan bentuk tes uraian atau tes unjuk kerja (tes performansi) sedangkan pada bagian tes formatif digunakan bentuk tes pilihan ganda.

Berkaitan dengan perwajahan bahan ajar, subjek penelitian mengharapkan bahan ajar memiliki cover yang sederhana, tetapi menarik. Pada setiap subbagian setiap kegiatan pembelajaran seharusnya diberikan identitas atau ciri khusus sehingga dapat membantu mahasiswa dalam mempelajari modul tersebut. 
Tabel 10

Rekapitulasi Kebutuhan Dosen

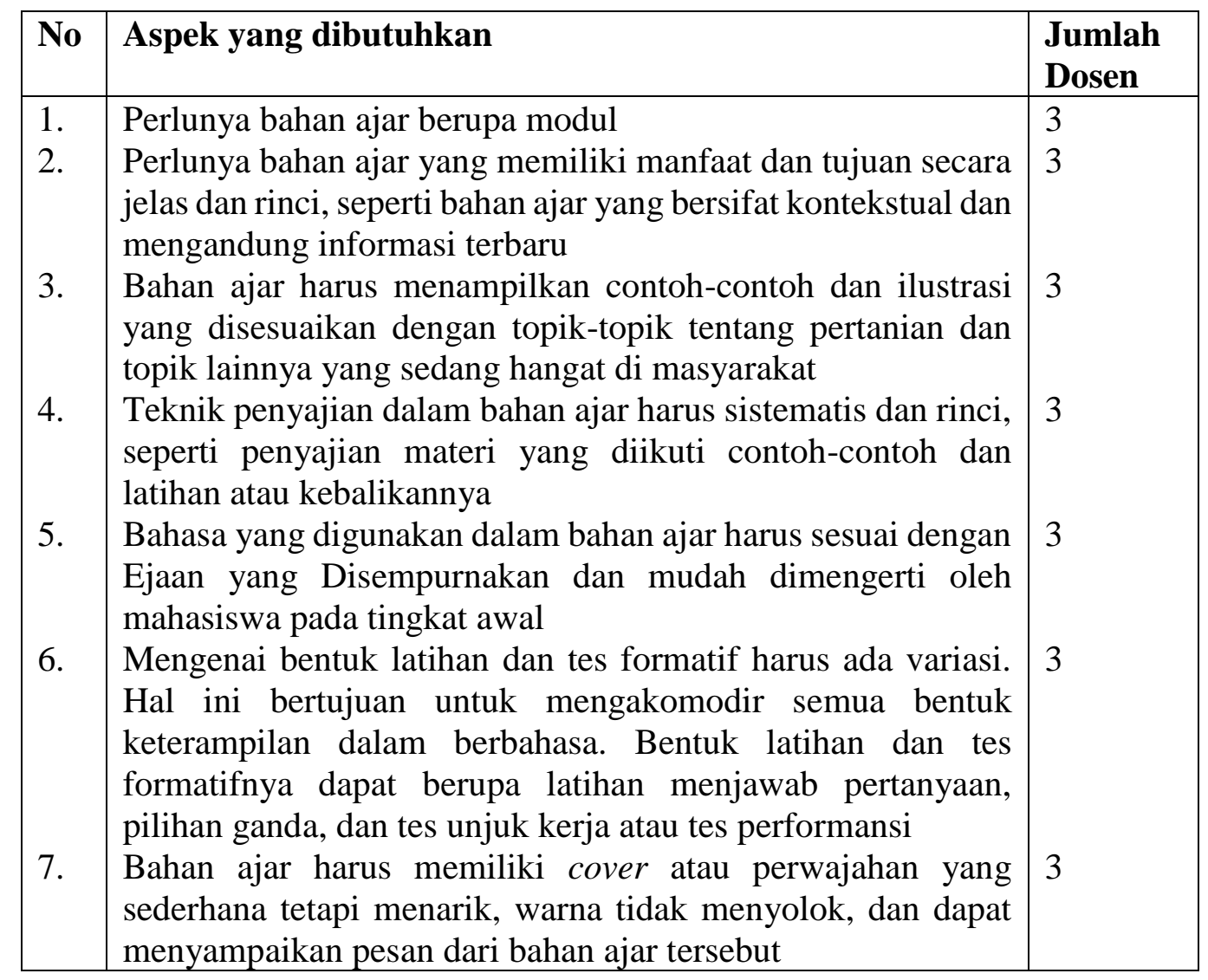

\section{Rancangan Bahan Ajar}

Rancangan modul ini disusun berdasarkan analisis kebutuhan mahasiswa dan dosen, kajian teori, dan analisis bahan ajar yang digunakan. Berdasarkan beberapa aspek tersebut disusunlah Modul MPK bahasa Indonesia untuk Perguruan Tinggi yang diharapkan dapat membantu pembelajaran mahasiswa dalam matakuliah umum bahasa Indonesia. Proses pengembangan modul ini didasarkan pada langkah-langkah pengembangan oleh Jolly dan Balitho.

Berdasarkan hasil identifikasi kebutuhan mahasiswa terhadap materi bahan ajar matakuliah bahasa Indonesia diperoleh beberapa informasi. Pertama, mahasiswa menganggap perlu adanya bahan ajar yang menunjang pembelajaran di kelas. Bahan ajar tersebut diharapkan mengakomodir segala kebutuhan pembelajaran seperti kelengkapan materi, contoh-contoh, latihan, tes formatif, 
jawaban, dan rubrik penilaian. Kedua, materi bahan ajar dalam modul yang dikembangkan dipilih oleh mahasiswa sesuai dengan kebutuhannya. Materi-materi yang dipilih tersebut merupakan perpaduan dari silabus MPK bahasa Indonesia di Universitas Muhammadiyah Palembang dan beberapa materi dari SK DIKTI nomor 43 tahun 2006.

Informasi lain juga didapatkan dari analisis kebutuhan mahasiswa ini. Informasi tersebut berupa gambaran kenyataan yang terjadi selama ini. Pembelajaran bahasa Indonesia sebelumnya hanya menggunakan buku atau bahan ajar yang hanya memuat unsur judul, materi, contoh, dan latihan saja. Di samping itu, bahan ajar tersebut tidak memiliki rubrik penilaian pada setiap kegiatan pembelajaran. Hal ini tentu menyulitkan bagi mahasiswa, apalagi bila materi yang disajikan berhubungan dengan unjuk kerja.

Setelah analisis kebutuhan mahasiswa, tahap selanjutnya adalah analisis kebutuhan para dosen. Informasi yang diperoleh dari para dosen tidak jauh berbeda dengan analisis kebutuhan bagi mahasiswa.

Tahap berikutnya adalah realisasi pedagogis yang diwujudkan dengan penyusunan petunjuk bahan ajar, materi pembahasan, latihan, rangkuman, dan tes formatif yang disajikan dalam modul bahasa Indonesia hasil pengembangan.

Selanjutnya adalah tahapan produksi bahan ajar. Bahan ajar yang dikembangkan adalah berupa Modul Bahasa Indonesia untuk Perguruan Tinggi. Sebelum uji coba lapangan terbatas, rancangan bahan ajar ini divalidasi terlebih dahulu oleh para pakar yang berkompeten di bidangnya.

Para pakar yang memvalidasi modul ini ada 4 orang. Aspek kebahasaan divalidasi oleh Drs. Haryadi, M.Pd. (Dosen Program Studi Pendidikan Bahasa dan Sastra Indonesia Universitas Muhammadiyah Palembang). Prof. Dr. Mulyadi Eko Purnomo, M.Pd. (Dosen Program Studi Pendidikan Bahasa PPS Unsri) yang memvalidasi aspek kelayakan materi/isi. Selanjutnya, aspek penyajian oleh Dr. didi Suhendi, S.Pd., M. Hum. (Dosen Program Studi Pendidikan Bahasa PPS Unsri) dan aspek kegrafikaan divalidasi oleh Prof. Dr. Fuad Abdul Rahman, M.Pd. (Dosen Program Studi Teknologi Pendidikan PPS Unsri). 
Berikut ini rancangan bahan ajar berdasarkan analisis kebutuhan.

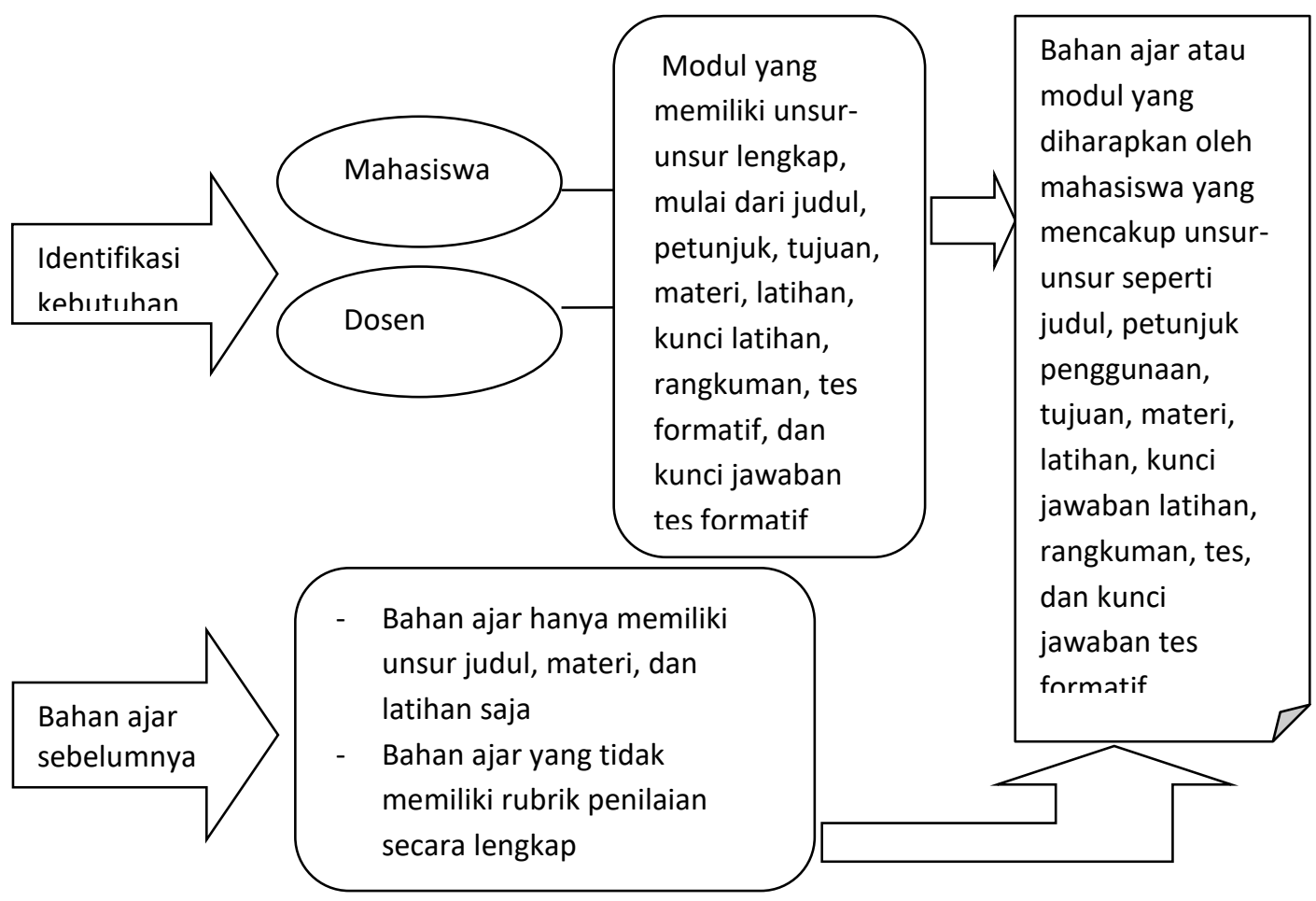

Bagan 4. Rancangan Bahan Ajar

Secara garis besar, modul yang dikembangkan ini terdiri dari 3 bagian, yaitu bagian awal, bagian isi, dan bagian akhir. Bagian pendahuluan terdiri atas (1) sampul atau cover berisi nama penulis, judul modul, dan topik-topik dalam modul, (2) daftar isi, (3) kata pengantar, dan (4) petunjuk penggunaan modul. Bagian isi terdiri dari beberapa bab atau modul. Tiap-tiap modul terbagi atas beberapa kegiatan pembelajaran yang lebih terperinci. Pada tiap pembelajaran dikembangkan lagi menjadi judul kegiatan, standar kompetensi, tujuan, uraian materi, latihan, kunci petunjuk latihan, rangkuman, tes formatif, patokan penilaian, kunci jawaban tes formatif, dan daftar pustaka. Bagian penutup berisi tentang biodata singkat penulis bahan ajar. 
Desain modul tersebut dapat digambarkan dengan gambar berikut ini.

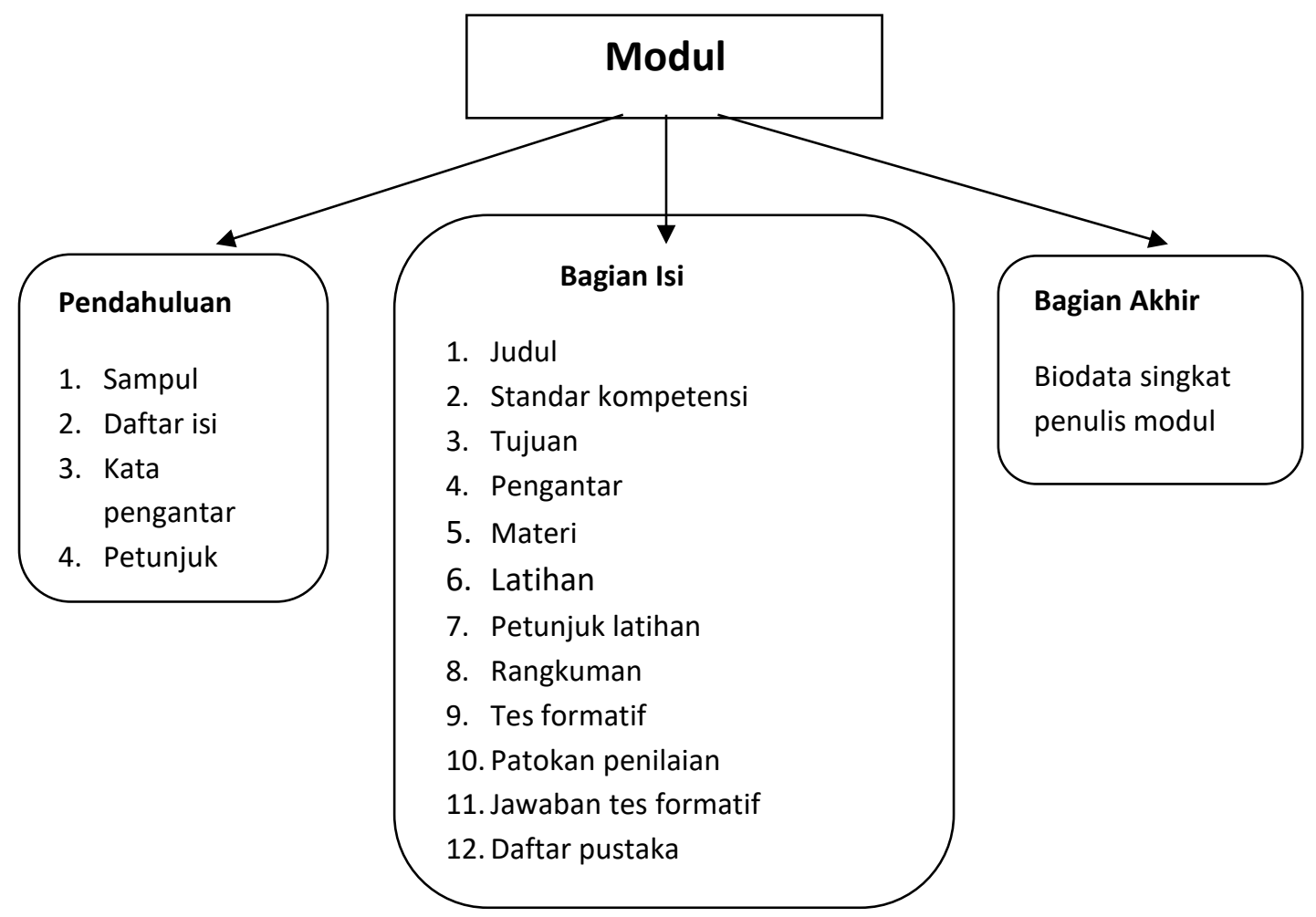

Bagan 5. Desain Modul

\section{Hasil Validasi}

Validasi terhadap modul MPK Bahasa Indonesia yang dikembangkan dalam penenlitian ini dilakukan dari tanggal 5 September 2013 sampai dengan 5 Oktober 2013. Validasi dilakukan untuk empat aspek, meliputi aspek kelayakan materi/isi, aspek penyajian, aspek kebahasaan, dan aspek kegrafikaan.

Pakar atau ahli yang menilai modul tersebut adalah Drs. Haryadi, M.Pd. (Dosen Program Studi Pendidikan Bahasa dan Sastra Indonesia Universitas Muhammadiyah Palembang) yang menilai aspek kebahasaan, Dr. Didi Suhendi, S.Pd., M. Hum. (Dosen Program Studi Bahasa Indonesia PPS Unsri) yang menilai aspek penyajian, Prof. Dr. Mulyadi Eko Purnomo, M.Pd. (Dosen Program Studi Bahasa Indonesia PPS Unsri) yang menilai aspek kelayakan materi, dan Prof. Dr. Fuad Abdul Rahman, M.Pd. (Dosen Program Studi Teknologi Pendidikan PPS Unsri) yang menilai aspek kegrafikaan. 
Instrumen validasi kepada pakar dibagi menjadi dua bagian. Bagian pertama berisi tabel penilaian yang berupa angka dengan skala $1-5$ (skala 5). Bagian kedua berisi tentang beberapa pertanyaan kepada validator untuk memberikan saran dan masukan untuk pengembangan modul.

Berdasarkan hasil penilaian ahli bahasa, modul MPK Bahasa Indonesia ini dikategorikan cukup. Dari 4 aspek yang dinilai dengan skala 5, aspek keterbacaan, kejelasan informasi, kesesuaian dengan kaidah bahasa Indonesia yang baik dan benar, dan pemanfaatan bahasa secara efektif dan efisien semuanya memperoleh nilai 3 (cukup). Secara keseluruhan, skor yang diperoleh untuk komponen kebahasaan adalah 12 dari skor maksimal 20.

Ada beberapa saran dari ahli/pakar aspek kebahasan. Pertama, perhatikan kembali tentang ejaan yang digunakan pada modul MPK bahasa Indonesia tersebut. Kedua, sebelum mencetak modul seharusnya diperiksa kembali tentang penulisan. Terakhir, validator memberikan saran untuk lebih fokus menelaah kata-kata yang sesuai untuk ragam tulis dan tidak menggunakan ragam bahasa lisan.

Penilaian terhadap beberapa komponen penyajian dapat dikatakan lebih bervariasi. Dari 5 aspek penyajian yang dinilai, 1 komponen mendapat nilai kurang (2), 1 komponen mendapat nilai cukup (3), dan 3 komponen mendapat nilai baik (4). Skor yang diperoleh untuk aspek penyajian adalah 17 dari skor maksimal 25.

Aspek berikutnya yang dinilai adalah kelayakan isi/materi. Pada aspek materi, validator memberikan nilai baik pada komponen kesesuaian silabus, kebenaran substansi materi, dan manfaat untuk menambah wawasan. Validator juga memberikan penilaian sangat baik untuk komponen kesesuaian dengan perkembangan mahasiswa. Namun, ada satu komponen yang tidak nilai oleh validator. Menurutnya, komponen tersebut merupakan ranah peneliti dalam mengembangkan modulnya dan bukan wewenang dari validator untuk menilainya. Hal itu disebabkan validator tidak terlibat langsung dalam analisis kebutuhan bahan ajar tersebut.

Aspek kelayakan materi mendapat jumlah nilai 17 dari total nilai 20. Nilai baik (4) diberikan oleh validator pada komponen kesesuaian dengan silabus, komponen kebenaran substansi materi, dan komponen manfaat untuk menambah 
wawasan/pengetahuan. Nilai sangat baik (5) diberikan pada komponen kesesuaian dengan perkembangan mahasiswa.

Saran-saran dan masukan dari aspek kelayakan materi ada beberapa hal. Pertama, saran-saran yang berkaitan dengan kelengkapan materi dan contohcontoh. Kelengkapan ini meliputi pemilihan contoh beberapa wacana yang tidak hanya berasal dari satu sumber referensi saja tetapi juga diharapkan lebih bervariatif. Kedua, saran-saran yang berkaitan dengan sistematika penulisan modul. Bagian ini lebih menyarankan beberapa hal yang berkaitan dengan ejaan dan beberapa subbahasan yang harus diubah sistematika urutannya.

Validator aspek penyajian memberikan beberapa saran dan masukan. Pertama, rumusan tujuan pembelajaran lebih jelas dan terarah. Artinya penyajian materi tentang sejarah, kedudukan, dan fungsi bahasa Indonesia lebih diarahkan pada kedudukan bahasa Indonesia sebagai bahasa nasional dan bahasa negara. Kedua, pada penyajian materi menulis akademik, validator memberikan saran untuk menambahkan materi tentang langkah-langkah mengembangkan menulis paragraf, esai, dan makalah. Ketiga, validator mengharapkan agar modul ini lebih diarahkan pada keterampilan berbahasa.

Aspek terakhir yang divalidasi adalah aspek kegrafikaan. Pada aspek ini mendapat penilaian yang seragam. Dari 4 komponen kegrafikaan, semuanya mendapat nilai baik (4). Keempat komponen yang mendapat nilai baik (4) tersebut meliputi: (a) penggunaan font, jenis huruf, dan ukuran, (b) lay out atau tata letak, (c) ilustrasi, gambar, dan foto, dan (d) desain tampilan. Secara keseluruhan, skor yang diperoleh adalah 16 dari skor maksimal 20.

Validator aspek kegrafikaan memberikan saran-saran tentang ukuran tulisan, kekonsistenan penggunaan jenis huruf pada kolom yang sama, dan tampilan luar (cover). Ukuran tulisan pada modul MPK bahasa Indonesia disarankan untuk diperbesar, hal ini dilakukan agar para mahasiswa dapat membaca tulisan dengan lebih mudah. Dalam hal kekonsistenan penggunaan jenis huruf, validator menyarankan untuk menggunakan jenis huruf yang sama pada kolom atau bagianbagian yang diberi ciri-ciri khusus, misalnya pada bagian tujuan pembelajaran dan rangkuman, seharusnya menggunakan jenis huruf yang sama. Pada bagian cover, 
validator menyarankan untuk memilih dan menentukan tema cover yang sesuai dengan isi modul. Di samping itu juga, sebuah cover diharapkan dapat memberikan informasi yang jelas kepada mahasiswa/pembaca tentang topik.

Tabel 11

Saran/komentar Pakar dan Hasil Revisi Bahan Ajar

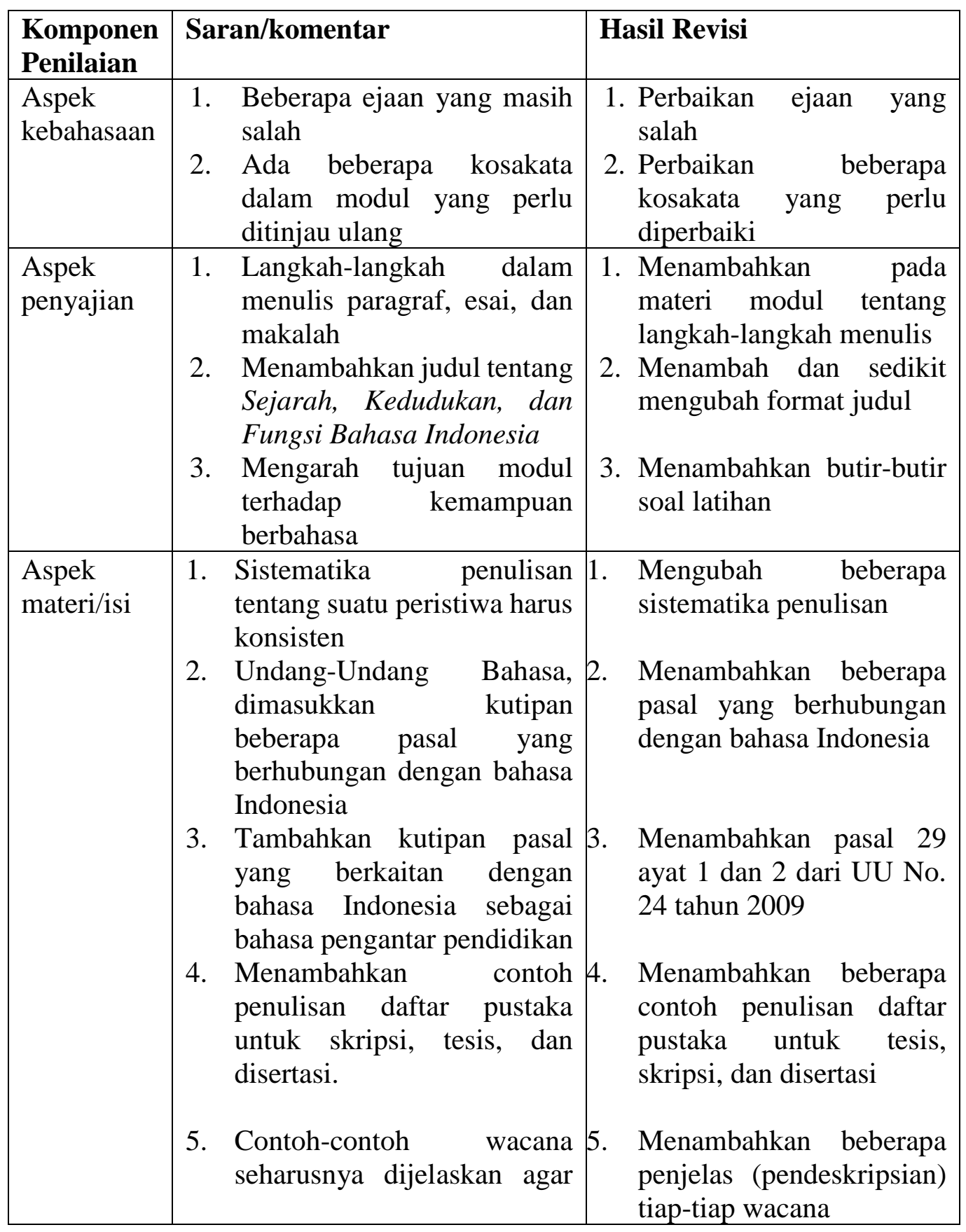




\begin{tabular}{|c|c|c|}
\hline & $\begin{array}{l}\text { mudah diidentifikasi oleh } \\
\text { mahasiswa } \\
\text { 6. Bahasan tentang berbicara } \\
\text { dalam situasi formal agar } \\
\text { lebih dibuat spesifik }\end{array}$ & $\begin{array}{l}\text { 6. Membuat lebih spesifik } \\
\text { dan khusus pada kegiatan } \\
\text { pembelajaran berbicara }\end{array}$ \\
\hline $\begin{array}{l}\text { Aspek } \\
\text { kegrafikaan }\end{array}$ & 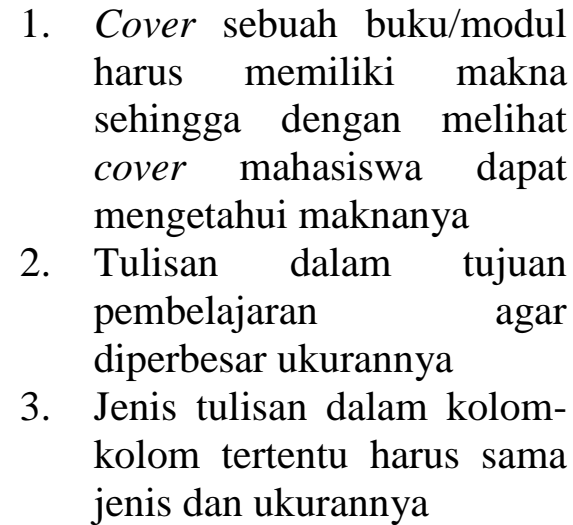 & $\begin{array}{l}\text { 2. Mengubah ukuran huruf } \\
\text { pada tujuan pembelajaran } \\
\text { 3. Mengubah jenis huruf } \\
\text { yang berbeda pada kolom } \\
\text { atau bagan yang sama }\end{array}$ \\
\hline
\end{tabular}

\section{Hasil Uji Lapangan}

Uji lapangan yang digunakan pada penelitian pengembangan ini adalah uji lapangan dengan menggunakan subjek yang sama, yaitu dengan cara menggunakan tes sebelum dan tes sesudah menggunakan bahan ajar hasil pengembangan. Teknik ini digunakan untuk mengetahui peningkatan hasil tes dari penggunaan bahan ajar hasil pengembangan.

Uji lapangan ini merupakan uji lapangan terbatas yang dilakukan di Fakultas Pertanian Universitas Muhammadiyah Palembang. Subjek dalam penelitian ini terdiri dari 37 mahasiswa kelas Agro A (satu kelas). Uji lapangan bahan ajar ini dimaksudkan untuk mengetahui dan mengukur kemampuan mahasiswa dalam memahami materi bahasa Indonesia, baik yang berupa tes formatif pilihan ganda maupun tes performansi (unjuk kerja). Tes formatif pilihan ganda ditujukan untuk mengukur pengetahuan mahasiswa secara teoritis sedangkan tes performansi ditujukan untuk melihat kemampuan mahasiswa dalam menulis esai dan kemampuan berbicara dalam presentasi. 


\section{a. Hasil Tes Formatif Pengetahuan Bahasa Indonesia}

\section{1) Nilai Tes Sebelum Menggunakan Modul}

Prates pilihan ganda untuk beberapa materi bahasa Indonesia dilakukan pada tanggal 7 Oktober 2013. Prates ini mencakup materi tentang (1) sejarah, kedudukan, dan fungsi bahasa Indonesia, (2) menulis paragraf, (3) menulis makalah, (3) kutipan dan daftar pustaka, dan (4) wacana.

Hasil prates pengetahuan umum pada 37 mahasiswa Fakultas Pertanian Universitas Muhammadiyah Palembang mendapatkan hasil yang bervariasi. Nilai tertinggi adalah 88 sebanyak 2 orang dan nilai terendah adalah 48 sebanyak 1 orang. Berdasarkan hasil perhitungan nilai rata-rata mahasiswa sebelum menggunakan bahan ajar hasil pengembangan peneliti adalah 66,38. Secara lebih rinci, nilai hasil prates yang dicapai oleh mahasiswa dapat dilihat pada tabel 12 .

\section{2) Nilai Tes Setelah Menggunakan Modul}

Tes formatif untuk pengetahuan bahasa Indonesia setelah menggunakan modul hasil pengembangan peneliti dilakukan pada tanggal 21 Oktober 2013. Tes ini diberikan kepada mahasiswa setelah sebelumnya diberikan bahan ajar untuk dipelajari secara mandiri.

Dari hasil tes formatif ini, diperoleh nilai yang bervariasi. Nilai tertinggi 96 yang diperoleh sebanyak 5 orang dan nilai terendah 60 sebanyak 2 orang. Dari total nilai tersebut, diperoleh nilai rata-rata (mean) untuk tes formatif sesudah menggunakan bahan ajar adalah 81,19. Dengan demikian, selisih nilai mahasiswa sebelum dan sesudah menggunakan bahan ajar hasil pengembangan adalah 14,81.

Berdasarkan hasil nilai rata-rata sebelum dan sesudah menggunakan modul, nilai tes formatif ini meningkat setelah menggunakan bahan ajar hasil pengembangan peneliti. Untuk lebih jelasnya, dapat dilihat pada tabel berikut ini. 
Tabel 12

Nilai Tes Formatif Pengetahuan Bahasa Indonesia

\begin{tabular}{|c|c|c|c|}
\hline No & Nama & Nilai Prates & Nilai Pascates \\
\hline 1. & IAN & 64 & 84 \\
\hline 2. & JRS & 56 & 76 \\
\hline 3. & EA & 68 & 84 \\
\hline 4. & $\mathrm{OP}$ & 64 & 88 \\
\hline 5. & MBI & 64 & 80 \\
\hline 6. & RI & 60 & 76 \\
\hline 7. & $\mathrm{ZU}$ & 88 & 96 \\
\hline 8. & SU & 80 & 96 \\
\hline 9. & $\mathrm{DP}$ & 64 & 84 \\
\hline 10. & $\mathrm{AM}$ & 64 & 80 \\
\hline 11. & $\mathrm{HI}$ & 72 & 92 \\
\hline 12. & DWP & 68 & 84 \\
\hline 13. & SA & 56 & 64 \\
\hline 14. & RYL & 64 & 84 \\
\hline 15. & IFS & 60 & 84 \\
\hline 16. & RA & 76 & 96 \\
\hline 17. & WA & 60 & 76 \\
\hline 18. & FS & 68 & 80 \\
\hline 19. & FA & 64 & 76 \\
\hline 20. & HDP & 60 & 76 \\
\hline 21. & $\mathrm{BA}$ & 76 & 72 \\
\hline 22. & AR & 64 & 72 \\
\hline 23. & SUM & 56 & 76 \\
\hline 24. & EHW & 76 & 88 \\
\hline 25. & MF & 76 & 80 \\
\hline 26. & AYD & 56 & 72 \\
\hline 27. & IA & 76 & 92 \\
\hline 28. & FAT & 56 & 60 \\
\hline 29. & SAA & 68 & 80 \\
\hline 30. & $\overline{\mathrm{ADG}}$ & 72 & 96 \\
\hline 31. & SUJ & 60 & 68 \\
\hline 32. & DUW & 88 & 96 \\
\hline 33. & $\mathrm{RE}$ & 68 & 80 \\
\hline 34. & RIK & 60 & 84 \\
\hline 35. & GG & 48 & 60 \\
\hline
\end{tabular}




\begin{tabular}{|l|l|l|l|}
\hline 36. & HPD & 64 & 80 \\
\hline $37 . \quad$ NR & 72 & 92 \\
\hline Jumlah & 2456 & 3004 \\
\hline Rata-rata & 66,38 & 81,19 \\
\hline Selisih & 14,81 & \\
\hline
\end{tabular}

Berdasarkan data dari tabel tersebut, dapat dilihat bahwa nilai tes pengetahuan bahasa Indonesia (pilihan ganda) mengalami peningkatan. Nilai terendah pada prates adalah 48 sedangkan pada pascates adalah 60. Nilai tertinggi pada prates adalah 88 dan pada pascates 96. Dari data tersebut, diperoleh selisih nilai terendah antara prates dan pascates adalah 12 sedangkan selisih nilai tertinggi adalah 8 . Secara lebih jelas dapat dilihat pada grafiks berikut.

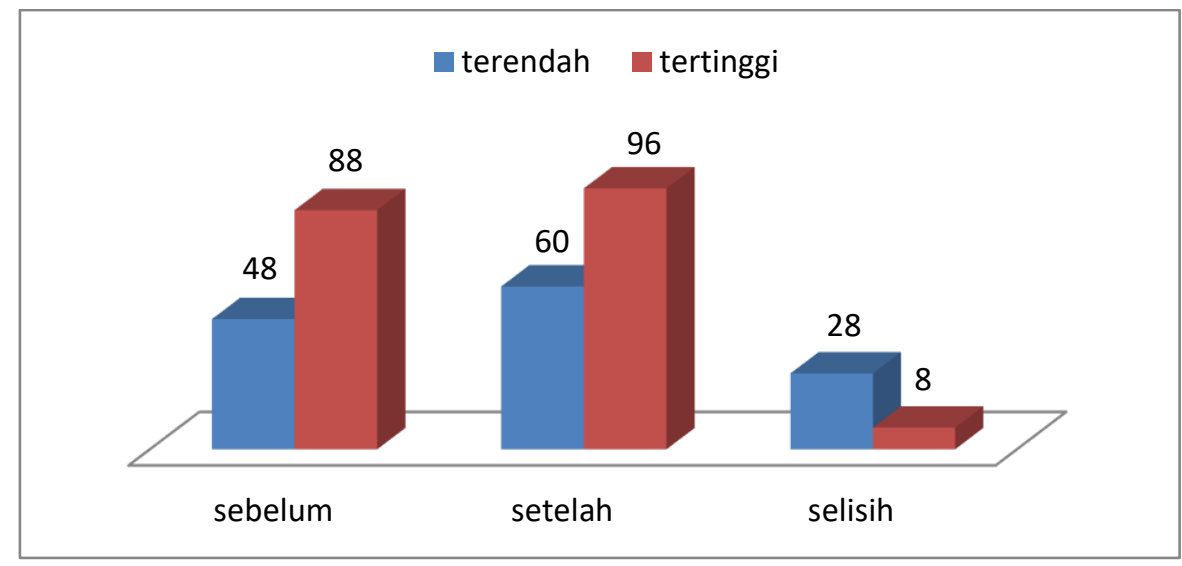

\section{Grafiks 1 Data Nilai Prates dan Pascates Pengetahuan Bahasa Indonesia}

Dari data tersebut juga dapat diperoleh informasi nilai rata-rata subjek penelitian. Nilai rata-rata (mean) pada prates adalah 66,38 sedangkan pada pascates adalah 81,19 . Sehingga dapat diperoleh nilai selisih dari nilai rata-rata tersebut adalah 14,81 . Secara jelasnya dapat dilihat pada grafiks 2 berikut. 


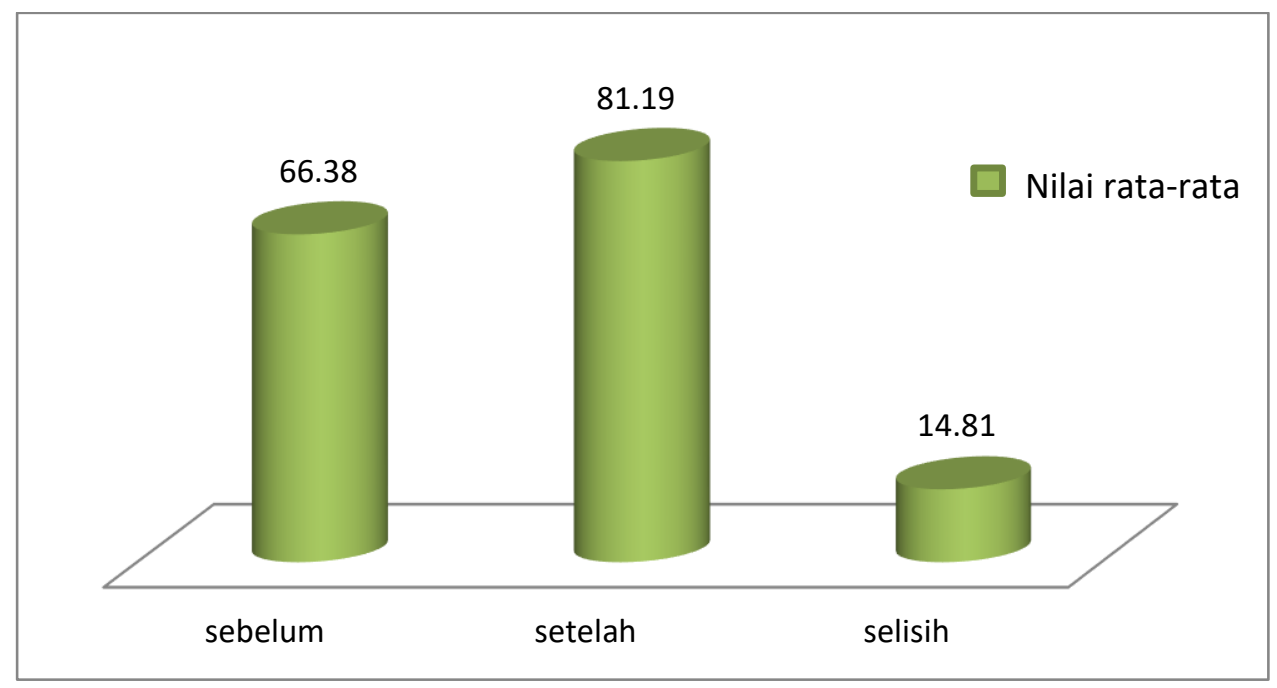

\section{Grafiks 2 Nilai Rata-rata Sebelum dan Setelah Menggunakan Modul pada Tes Kemampuan Bahasa Indonesia}

\section{b. Hasil Tes Menulis Esai}

\section{Nilai Tes Sebelum Menggunakan Modul}

Prates menulis esai sebelum menggunakan modul ini dilakukan pada tanggal 8 Oktober 2013. Tes menulis esai ini diberikan dengan berbagai tema, yaitu tema pertanian, teknologi, dan Isu-isu terkini. Subjek penelitian diberikan keleluasaan untuk memilih salah satu dari 3 tema besar tersebut. Dari ketiga tema tersebut, subjek penelitian bebas untuk menyempitkan temanya sehingga lebih spesifik.

Berdasarkan hasil prates menulis esai tersebut diperoleh nilai yang bervariasi. Nilai tertinggi 81 sebanyak empat orang. Sementara, nilai terendah pada prates menulis esai ini adalah 48 sebanyak dua orang. Dari hasil perhitungan nilai tersebut diperoleh nilai rata-rata (mean) sebelum menggunakan modul adalah 67,54. Nilai secara keseluruhan yang diperoleh oleh subjek penelitian, khususnya nilai prates dapat dilihat pada tabel 13 .

\section{Nilai Tes Menulis Esai Setelah Menggunakan Modul}

Tes menulis esai setelah menggunakan modul dilaksanakan pada tanggal 22 Oktober 2013. Tes ini dilakukan setelah subjek penelitian diberikan modul seminggu sebelumnya dan diberikan proses belajar mengajar di kelas. Pada 
pascates menulis esai ini, subjek penelitian diharuskan menulis esai sesuai dengan tema yang dipilih pada prates yaitu tema pertanian, teknologi, dan isu-isu terkini.

Berdasarkan hasil pascates menulis esai tersebut diperoleh nilai yang cukup bervariasi. Nilai tertinggi pada tes menulis esai setelah menggunakan modul 91 sebanyak dua orang dan untuk nilai terendah adalah 57 sebanyak satu orang. Nilai rata-rata yang diperoleh pada pascates ini adalah 78,41 yang artinya mengalami peningkatan dari nilai prates sebelumnya.

Berdasarkan dari data nilai rata-rata tersebut, dapat dihitung selisih antara nilai prates dan pascates menulis esai. Selisih nilai tersebut adalah 10,9. Dengan demikian, dapat disimpulkan bahwa nilai mahasiswa dalam menulis esai dinyatakan meningkat setelah menggunakan bahan ajar hasil pengembangan peneliti. Berikut data secara rinci dari nilai prates dan pascates menulis esai.

Tabel 13

Nilai Tes Menulis Esai

\begin{tabular}{|l|l|l|l|}
\hline No & Nama & Nilai Prates & Nilai Pascates \\
\hline 1. & IAN & 67 & 81 \\
\hline 2. & JRS & 57 & 67 \\
\hline 3. & EA & 67 & 71 \\
\hline 4. & OP & 71 & 76 \\
\hline 5. & MBI & 62 & 76 \\
\hline 6. & RI & 48 & 67 \\
\hline 7. & ZU & 81 & 86 \\
\hline 8. & SU & 76 & 81 \\
\hline 9. & DP & 62 & 86 \\
\hline 10. & AM & 67 & 76 \\
\hline 11. & HI & 81 & 86 \\
\hline 12. & DWP & 71 & 76 \\
\hline 13. & SA & 71 & 81 \\
\hline 14. & RYL & 67 & 86 \\
\hline 15. & IFS & 71 & 86 \\
\hline 16. & RA & 81 & 86 \\
\hline 17. & WA & 67 & 71 \\
\hline 18. & FS & 62 & 71 \\
\hline 19. & FA & 48 & 67 \\
\hline 20. & HDP & 67 & 76 \\
\hline 21. & BA & 71 & 86 \\
\hline 22. & AR & 76 & 81 \\
\hline & & & \\
\hline
\end{tabular}




\begin{tabular}{|l|l|l|l|}
\hline 23. & SUM & 52 & 57 \\
\hline 24. & EHW & 67 & 76 \\
\hline 25. & MF & 67 & 81 \\
\hline 26. & AYD & 57 & 76 \\
\hline 27. & IA & 71 & 91 \\
\hline 28. & FAT & 76 & 86 \\
\hline 29. & SAA & 71 & 86 \\
\hline 30. & ADG & 76 & 76 \\
\hline 31. & SUJ & 67 & 71 \\
\hline 32. & DUW & 81 & 91 \\
\hline 33. & RE & 52 & 76 \\
\hline 34. & RIK & 71 & 86 \\
\hline 35. & GG & 57 & 71 \\
\hline 36. & HPD & 76 & 81 \\
\hline 37. & NR & 67 & 76 \\
\hline Jumlah & 2499 & 2901 \\
\hline Rata-rata (Mean) & 67,54 & 78,41 \\
\hline Selisih & 10,9 & \\
\hline
\end{tabular}

Dari data tersebut diperoleh informasi tentang nilai tertinggi dan terendah pada prates dan pascates. Nilai tertinggi pada prates adalah 81, sedangkan pada pascates adalah 91. Nilai terendah pada prates menulis esai 48 dan pada pascates 57. Artinya, ada peningkatan kemampuan mahasiswa setelah menggunakan bahan ajar hasil pengembangan. Peningkatan tersebut dapat dilihat dari nilai selisihnya, yaitu selisih nilai terendah 9 sedangkan nilai tertinggi adalah 10. Untuk lebih jelasnya dapat dilihat pada grafiks 3 berikut.

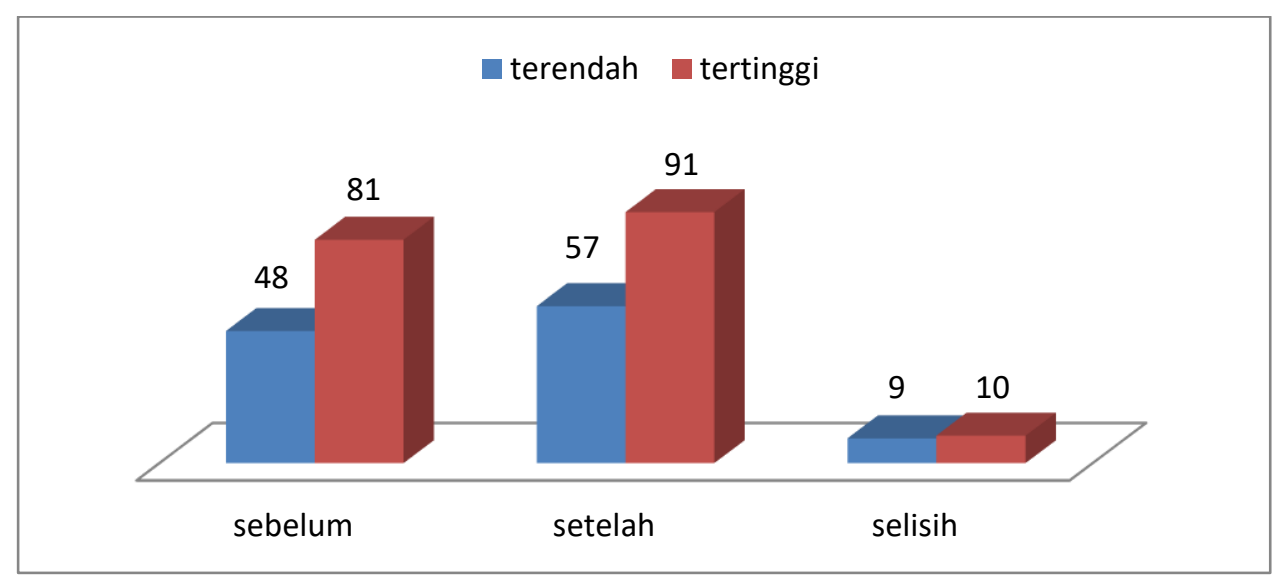

Grafiks 3 Nilai Prates dan Pascates Menulis Esai 
Berdasarkan data tersebut dapat dilihat nilai yang diperoleh mahasiswa setelah menggunakan modul mengalami peningkatan. Hal tersebut dapat dilihat dari nilai rata-rata (mean) sebelum menggunakan modul 67,54 sedangkan nilai rata-rata setelah menggunakan modul 78,41. Secara rinci dapat dilihat pada grafiks 4 berikut ini.

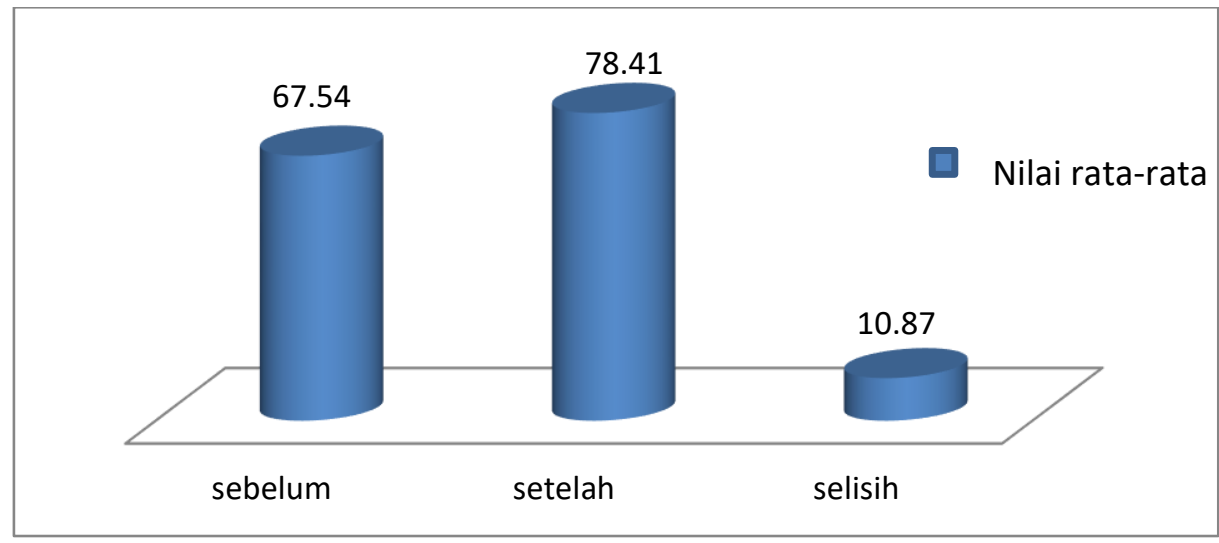

\section{Grafiks 4 Nilai Rata-rata Menulis Esai Sebelum dan Setelah Menggunakan Modul}

\section{c. Hasil Tes Berbicara untuk Presentasi}

\section{Nilai Tes Sebelum Menggunakan Modul}

Tes berbicara untuk presentasi dilakukan pada tanggal 9-11 Oktober 2013. Prates berbicara ini dilaksanakan sampai tiga kali pertemuan disebabkan subjek penelitiannya yang berjumlah 37 orang. Durasi yang diberikan pada masing-masing subjek penelitian maksimal 10 menit.

Dari hasil tes berbicara untuk presentasi yang dilakukan pada 37 mahasiswa, diperoleh nilai yang cukup bervariasi. Nilai tertinggi pada prates ini adalah 79 sebanyak dua orang dan nilai terendah 57 sebanyak empat orang. Dari data tersebut juga diperoleh nilai rata-rata tes berbicara untuk presentasi sebelum menggunakan modul adalah 67,11 . Nilai prates secara lengkap pada tes berbicara ini dapat dilihat pada tabel 14. 


\section{Nilai Tes Setelah Menggunakan Modul}

Tes berbicara untuk presentasi setelah menggunakan modul dilakukan pada tanggal 23-25 Oktober 2013. Tes ini dilakukan kepada 37 mahasiswa setelah diberikan materi tentang berbicara dan memberikan modul Bahasa Indonesia untuk Perguruan Tinggi kepada subjek penelitian seminggu sebelumnya. Pemberian modul ini bertujuan untuk mengarahkan subjek penelitian dalam mempelajari modul secara mandiri.

Berdasarkan hasil tes diperoleh nilai dari semua subjek penelitian. Nilai tertinggi yang diperoleh 93 sebanyak dua orang, sedangkan nilai terendah 71 sebanyak tiga orang. Dari nilai tes setelah menggunakan modul tersebut, diperoleh nilai rata-rata 81,3. Dari nilai rata-rata pada prates dan pascates berbicara untuk presentasi diperoleh selisih 14,19. Artinya, ada peningkatan nilai yang signifikan setelah subjek penelitian menggunakan modul hasil pengembangan peneliti. Adapun perincian data hasil prates dan pascates berbicara untuk presentasi dapat dilihat pada tabel 14 berikut.

Tabel 14

Nilai Tes Berbicara untuk Presentasi

\begin{tabular}{|l|l|l|l|}
\hline No & Nama & Nilai Prates & Nilai Pascates \\
\hline 1. & IAN & 68 & 82 \\
\hline 2. & JRS & 68 & 86 \\
\hline 3. & EA & 64 & 75 \\
\hline 4. & OP & 71 & 89 \\
\hline 5. & MBI & 57 & 71 \\
\hline 6. & RI & 61 & 79 \\
\hline 7. & ZU & 68 & 75 \\
\hline 8. & SU & 61 & 79 \\
\hline 9. & DP & 68 & 82 \\
\hline 10. & AM & 71 & 79 \\
\hline 11. & HI & 75 & 93 \\
\hline 12. & DWP & 71 & 89 \\
\hline 13. & SA & 68 & 82 \\
\hline 14. & RYL & 64 & 75 \\
\hline 15. & IFS & 61 & 75 \\
\hline 16. & RA & 64 & 79 \\
\hline 17. & WA & 71 & 86 \\
\hline 18. & FS & 71 & 82 \\
\hline & & & \\
\hline
\end{tabular}




\begin{tabular}{|l|l|l|l|}
\hline 19. & FA & 71 & 82 \\
\hline 20. & HDP & 64 & 71 \\
\hline 21. & BA & 68 & 79 \\
\hline 22. & AR & 68 & 82 \\
\hline 23. & SUM & 57 & 75 \\
\hline 24. & EHW & 79 & 89 \\
\hline 25. & MF & 71 & 82 \\
\hline 26. & AYD & 71 & 86 \\
\hline 27. & IA & 64 & 82 \\
\hline 28. & FAT & 68 & 86 \\
\hline 29. & SAA & 71 & 89 \\
\hline 30. & ADG & 79 & 86 \\
\hline 31. & SUJ & 57 & 79 \\
\hline 32. & DUW & 71 & 93 \\
\hline 33. & RE & 68 & 86 \\
\hline 34. & RIK & 68 & 82 \\
\hline 35. & GG & 57 & 71 \\
\hline 36. & HPD & 68 & 75 \\
\hline 37. & NR & 61 & 75 \\
\hline Jumlah & 2483 & 3008 \\
\hline Rata-rata (Mean) & 67,11 & 81,3 \\
\hline Selisih & 14,19 & \\
\hline
\end{tabular}

Dari tabel data nilai tersebut, diperoleh informasi tentang nilai tertinggi pada tes berbicara 79 dan nilai terendah adalah 57. Pada tes setelah menggunakan bahan ajar nilai tertinggi adalah 93 dan nilai terendah 71. Dari tabel tersebut juga dapat dihitung selisih nilai tertinggi adalah 14 dan terendah 22. Secara jelas dapat dilihat pada grafiks 5 berikut ini.

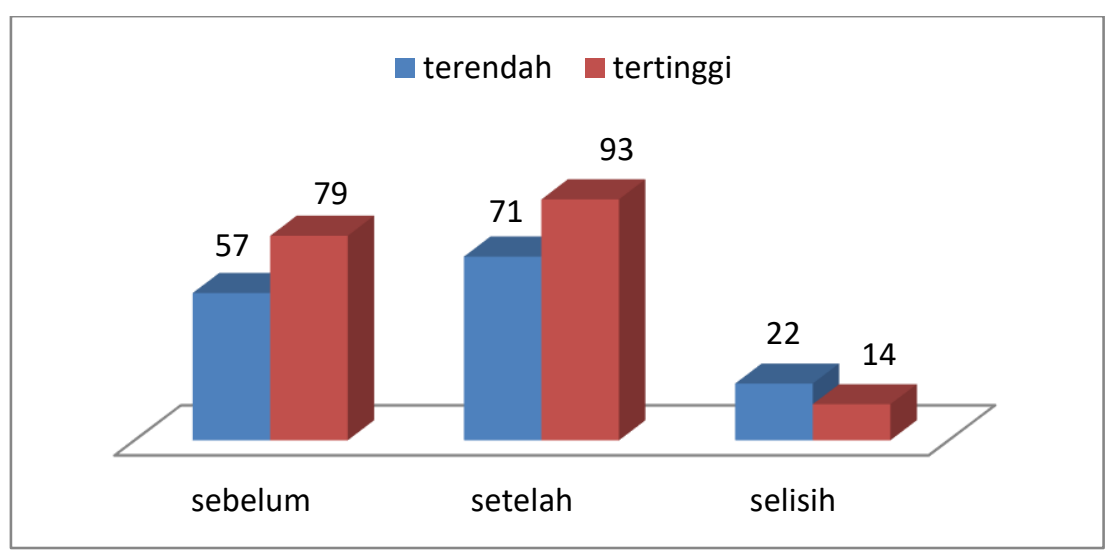

Grafiks 5 Nilai Prates dan Pascates Berbicara 
Selanjutnya, data nilai tersebut juga menunjukkan adanya peningkatan kemampuan mahasiswa dilihat dari nilai rata-ratanya. Nilai rata-rata sebelum menggunakan modul adalah 67,11 dan setelah menggunakan modul adalah 81,3. Berdasarkan nilai rata-rata sebelum dan setelah menggunakan modul, diperoleh selisih 14,19. Lebih lanjut, dapat dilihat pada grafiks 6 berikut ini.

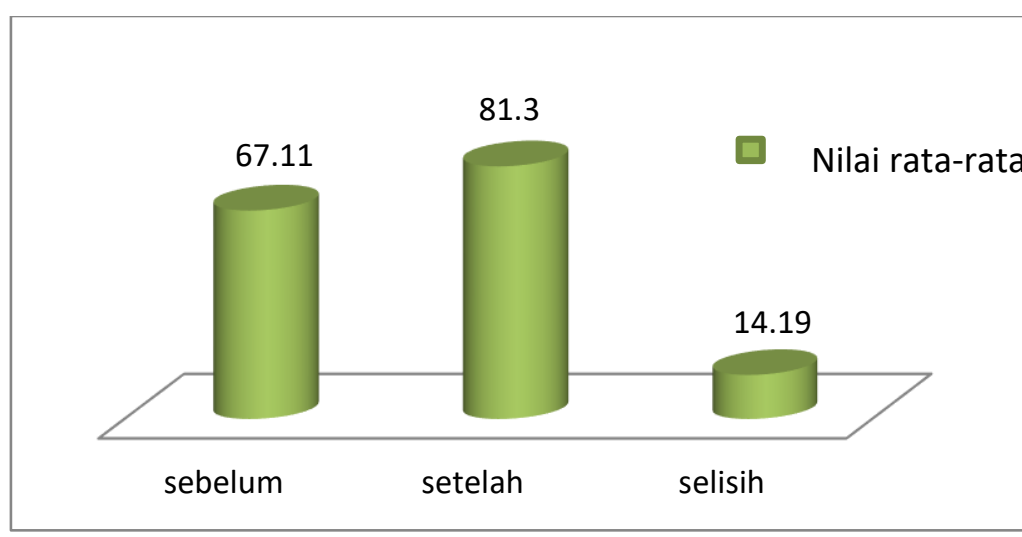

\section{Grafiks 6 Nilai Rata-rata Berbicara Sebelum dan Sesudah Menggunakan Modul}

\section{Hasil Uji Statistik}

Setelah data prates dan pascates diketahui, selanjutnya dilakukan uji statistik. Uji statistik ini bertujuan untuk mengetahui perbedaan antara kemampuan mahasiswa sebelum dan sesudah menggunakan modul hasil pengembangan peneliti. Hal-hal yang yang dihitung dalam uji statistik ini meliputi uji statistik deskriptif, uji normalitas, dan uji-t. Hasil-hasil uji statistik tersebut dijabarkan pada bagian-bagian berikut ini. 


\section{a. Hasil Uji Statistik Deskriptif, Normalitas, dan Uji-t pada Tes Pengetahuan Bahasa Indonesia}

Tabel 15

Statistik Deskriptif Nilai Tes Kemampuan Umum

\begin{tabular}{|l|r|r|r|r|r|r|}
\hline & $\mathrm{N}$ & Minimum & Maximum & Sum & Mean & $\begin{array}{c}\text { Std. } \\
\text { Deviation }\end{array}$ \\
\hline pretest & 37 & 48 & 88 & 2456 & 66.38 & 8.917 \\
posttest & 37 & 60 & 96 & 3004 & 81.19 & 9.701 \\
Valid N (listwise) & 37 & & & & & \\
\hline
\end{tabular}

Tabel tersebut menunjukkan nilai terendah pada prates pengetahuan bahasa indonesia adalah 48, sedangkan nilai tertinggi 88. Dari nilai prates tersebut diperoleh nilai rata-rata 66,38 dengan standar deviasi 8,917. Sementara itu, nilai terendah pada pascates kemampuan umum 60, sedangkan nilai tertinggi adalah 96. Dari tabel tersebut, diperoleh juga nilai rata-rata pascates 81,19 dengan standar deviasi 9,7.

Langkah selanjutnya, data nilai yang diperoleh baik prates maupun pascates diuji normalitasnya. Konsep dasarnya dengan membandingkan distribusi data (data yang akan diuji normalitasnya) dengan distribusi normal baku. Distribusi normal baku adalah data yang ditransformasikan ke dalam bentuk Z-score (diasumsikan sudah normal). Uji Kolmogorov Smirnov adalah uji normalitas dengan tujuan untuk mengetahui apakah data nilai yang diperoleh mahasiswa tersebut normal atau tidak. Berikut hasil uji normalitas tes pengetahuan bahasa Indonesia dengan menggunakan Sample Kolmogorov-Smirnov Test. 


\begin{tabular}{|l|r|r|}
\hline & pretest & Posttest \\
\hline Nean & 37 & 37 \\
Std. Deviation & 66.38 & 81.19 \\
Absolute & 8.917 & 9.701 \\
Positive & .173 & .116 \\
Negative & .173 & .116 \\
Kolmogorov-Smirnov Z & -.095 & -.107 \\
Asymp. Sig. (2-tailed) & 1.051 & .704 \\
\hline
\end{tabular}

Informasi yang dapat diuraikan dari tabel tersebut adalah uji normalitas pada data nilai tes kemampuan umum menunjukkan signifikan (2-tailed) pada prates 0,22 dan pascates 0,705 . Kedua angka tersebut menunjukkan bahwa data prates dan pascates dapat diasumsikan normal. Alasannya, nilai 0,22 dan 0,705 lebih besar dari 0,05. Dengan demikian, dapat dideskripsikan bahwa data prates dan pascates nilai tes kemampuan umum memiliki signifikasi di atas 0,05 . Jika signifikasinya di atas 0,05 maka data tersebut tidak terjadi perbedaan dengan data distribusi normal baku.

Dalam melihat normalitas data tersebut, dapat digambarkan pada kurva 1 untuk prates dan kurva 2 untuk pascates.

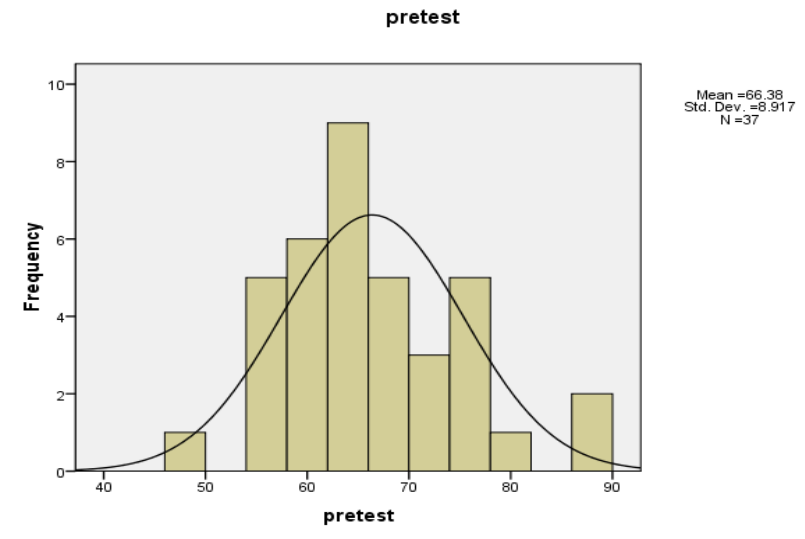

Kurva 1. Uji Normalitas Prates Pengetahuan bahasa Indonesia 
Pada kurva 1 di atas dapat dideskripsikan tentang penyajian data melalui diagram batang dan kurvanya. Sumbu mendatar menyatakan kelas interval nilai, sedangkan sumbu tegak untuk menyatakan frekuensi. Kurva yang ditunjukkan pada diagram tersebut dinyatakan sebagai kurva normal karena bentuknya yang simetrik dan mempunyai sebuah puncak.

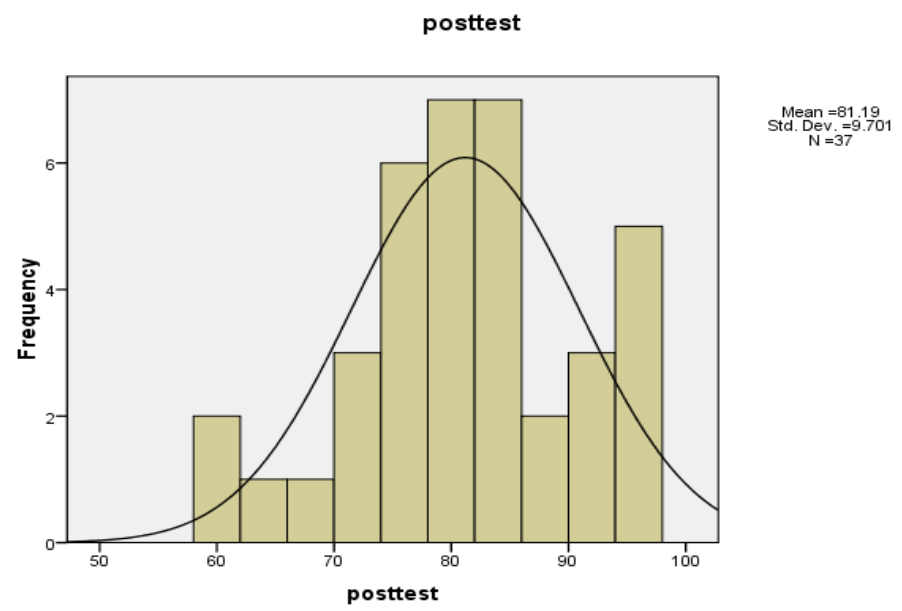

Kurva 2. Uji Normalitas Pascates Pengetahuan Bahasa Indonesia

Pada kurva 2, histogram tersebut menyajikan tentang distribusi frekuensi pada tiap-tiap kelas interval. Dari histogram tersebut dapat dibaca tentang data nilai pascates dengan jumlah mahasiswa yang mencapai nilai tersebut (frekuensi). Kurva yang ditampilkan pada histogram di atas dinyatakan normal karena berbentuk simetris dan membentuk puncak (peak).

Berikutnya, data tes kemampuan umum tersebut dilakukan uji-t. Uji-t dilakukan untuk mengetahui apakah ada perbedaan yang signifikan antara nilai sebelum dan setelah mahasiswa menggunakan bahan ajar. Uji-t ini dilakukan dengan menggunakan Paired Sample uji-t melalui SPSS 16. Hasil perhitungan uji$\mathrm{t}$ tersebut dapat dilihat pada tabel 17 berikut. 
Tabel 17

Hasil Uji-t Pengetahuan Bahasa Indonesia

Paired Samples Test

\begin{tabular}{|c|c|c|c|c|c|c|c|c|}
\hline & \multicolumn{5}{|c|}{ Paired Differences } & \multirow[b]{3}{*}{$\mathrm{t}$} & \multirow[b]{3}{*}{$d f$} & \multirow{3}{*}{$\begin{array}{l}\text { Sig. (2- } \\
\text { tailed) }\end{array}$} \\
\hline & \multirow[b]{2}{*}{ Mean } & \multirow{2}{*}{$\begin{array}{c}\text { Std. } \\
\text { Deviation }\end{array}$} & \multirow{2}{*}{$\begin{array}{l}\text { Std. } \\
\text { Error } \\
\text { Mean }\end{array}$} & \multicolumn{2}{|c|}{$\begin{array}{l}95 \% \text { Confidence Interval } \\
\text { of the Difference }\end{array}$} & & & \\
\hline & & & & Lower & Upper & & & \\
\hline $\begin{array}{c}\text { Pair } 1 \text { posttest - } \\
\text { pretest }\end{array}$ & 14.811 & 6.315 & 1.038 & 12.705 & 16.916 & 14.266 & 36 & .000 \\
\hline
\end{tabular}

Dari tabel tersebut diperoleh informasi tentang hasil uji-t Paired Sample Test dengan nilai rata-rata pada prates dan14,81 dengan pascates standar deviasi 6,315 dan sig $(2$-tailed $)=0,00$. Artinya, ada perbedaan yang signifikan antara nilai sebelum dan setelah mahasiswa menggunakan bahan ajar hasil pengembangan peneliti. Hal itu didasarkan pada nilai sig (2-tailed) 0,00 lebih kecil dari nilai alfa 0,05 (alpha value).

\section{b. Hasil Uji Statistik Deskriptif, Normalitas, dan Uji-t Tes Menulis Esai}

Data nilai menulis esai yang dilakukan pada 37 mahasiswa diolah dengan menggunakan uji statistik deskriptif. Uji ini dilakukan pada nilai mahasiwa sebelum dan setelah menggunakan bahan ajar hasil pengembangan peneliti dan digambarkan pada tabel 18 berikut ini.

Tabel 18

Statistik Deskriptif Nilai Menulis Esai

\begin{tabular}{|l|r|r|r|r|r|r|}
\hline & N & Minimum & Maximum & \multicolumn{1}{c|}{ Sum } & Mean & Std. Deviation \\
\hline pretest & 37 & 48 & 81 & 2499 & 67.54 & 8.903 \\
posttest & 37 & 57 & 91 & 2901 & 78.41 & 7.665 \\
Valid N (listwise) & 37 & & & & & \\
\hline
\end{tabular}


Tabel 18

Statistik Deskriptif Nilai Menulis Esai

\begin{tabular}{|l|r|r|r|r|r|r|}
\hline & N & Minimum & Maximum & Sum & Mean & Std. Deviation \\
\hline pretest & 37 & 48 & 81 & 2499 & 67.54 & 8.903 \\
posttest & 37 & 57 & 91 & 2901 & 78.41 & 7.665 \\
\hline
\end{tabular}

Tabel di atas menunjukkan nilai terendah pada prates menulis esai adalah 48, sedangkan nilai tertinggi 81 . Dari nilai prates tersebut diperoleh nilai rata-rata 67,54 dengan standar deviasi 8,903. Sementara itu, nilai terendah pada pascates tes kemampuan umum 57, sedangkan nilai tertinggi adalah 91. Dari tabel tersebut, diperoleh juga nilai rata-rata pascates 78,41 dengan standar deviasi 7,665.

Langkah selanjutnya adalah uji normalitas dengan tujuan untuk mengetahui apakah data nilai yang diperoleh mahasiswa tersebut normal atau tidak. Berikut tabel hasil uji normalitas tes menulis esai.

Tabel 19

Uji Normalitas Nilai Menulis Esai

One-Sample Kolmogorov-Smirnov Test

\begin{tabular}{|c|c|c|c|}
\hline & & pretest & Posttest \\
\hline \multicolumn{2}{|l|}{$\mathrm{N}$} & 37 & 37 \\
\hline \multirow[t]{2}{*}{ Normal Parameters ${ }^{a}$} & Mean & 67.54 & 78.41 \\
\hline & Std. Deviation & 8.903 & 7.665 \\
\hline \multirow[t]{3}{*}{ Most Extreme Differences } & Absolute & .206 & .163 \\
\hline & Positive & .106 & .137 \\
\hline & Negative & -.206 & -.163 \\
\hline Kolmogorov-Smirnov Z & & 1.250 & .994 \\
\hline Asymp. Sig. (2-tailed) & & .088 & .276 \\
\hline
\end{tabular}

Informasi yang dapat diinterpretasikan dari tabel tersebut adalah uji normalitas dengan menggunakan uji Kolmogorov Smirnov pada data nilai tes kemampuan umum menunjukkan signifikan (2-tailed) pada prates 0,088 dan pascates 0,276 . Kedua angka tersebut menunjukkan bahwa data prates dan pascates dapat diasumsikan sudah normal. Alasannya, nilai 0,088 dan 0,276 lebih besar dari 
0,05 sehingga dapat dideskripsikan bahwa kedua nilai tersebut tidak mengalami perbedaan yang signifikan dibandingkan dengan data distribusi normal baku (data Z-Score). Dalam melihat normalitas data tersebut, dapat digambarkan pada kurva 1 untuk prates dan kurva 2 untuk pascates.

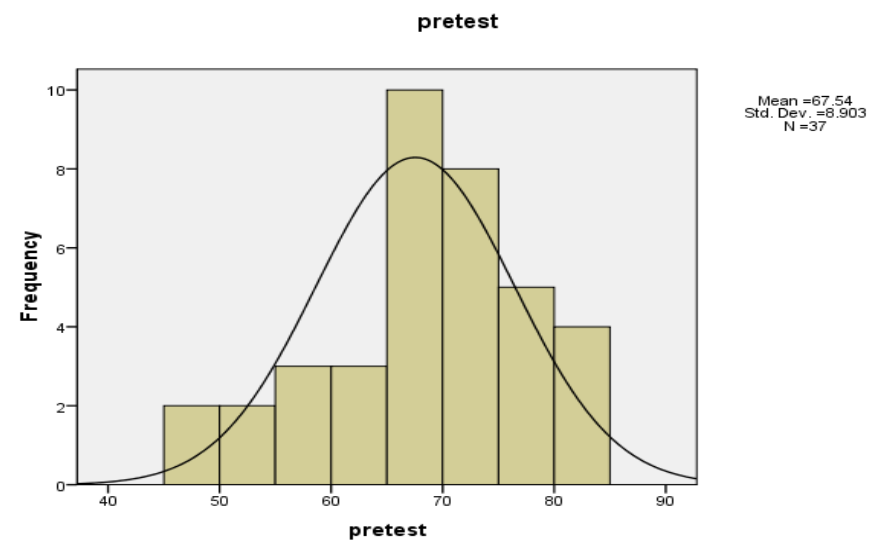

\section{Kurva 3 Uji Normalitas Prates Menulis Esai}

Histogram di atas menyajikan distribusi frekuensi nilai prates menulis esai. Sumbu tegak lurus menyatakan frekuensi atau jumlah mahasiswa dan sumbu mendatar menyatakan batas-batas kelas interval. Dari histogram tersebut dapat dideskripsikan distribusi frekuensi nilai mahasiswa, misalnya rentang nilai $65-70$ adalah 10 orang. Kurva yang ditampilkan merupakan kurva normal karena membentuk satu puncak.

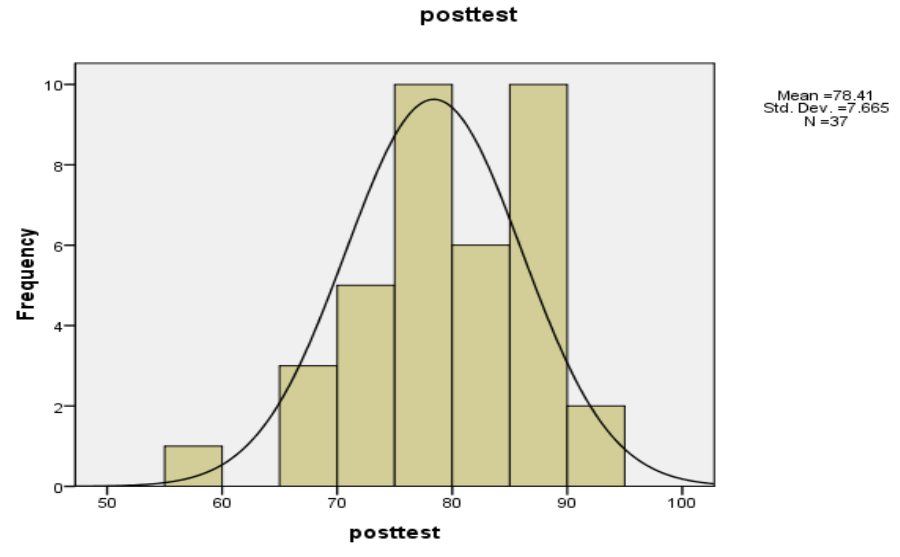

Kurva 4 Uji Normalitas Pascates Menulis Esai 
Seperti pada kurva sebelumnya, histogram ini juga menunjukkan kurva yang normal karena bentuknya tidak condong ke kiri ataupun ke kanan. Kurva dinyatakan normal jika berbentuk simetris dan membentuk puncak. Jadi data nilai pascates menulis esai ini dinyatakan normal melalui kurva tersebut.

Selanjutnya, data tes menulis esai tersebut dilakukan uji-t. Uji-t dilakukan untuk mengetahui apakah ada perbedaan yang signifikan antara nilai sebelum dan setelah mahasiswa menggunakan bahan ajar. Uji-t ini dilakukan dengan menggunakan Paired Sample uji-t melalui SPSS 16. Hasil perhitungan uji-t tersebut dapat dilihat pada tabel 20 berikut.

Tabel 20

Hasil Uji-t Menulis Esai

\begin{tabular}{|c|c|c|c|c|c|c|c|c|}
\hline & \multicolumn{5}{|c|}{ Paired Differences } & \multirow[b]{3}{*}{$\mathrm{T}$} & \multirow[b]{3}{*}{$d f$} & \multirow{3}{*}{$\begin{array}{l}\text { Sig. (2- } \\
\text { tailed) }\end{array}$} \\
\hline & \multirow[b]{2}{*}{ Mean } & \multirow{2}{*}{$\begin{array}{c}\text { Std. } \\
\text { Deviation }\end{array}$} & \multirow{2}{*}{$\begin{array}{l}\text { Std. Error } \\
\text { Mean }\end{array}$} & \multicolumn{2}{|c|}{$\begin{array}{c}95 \% \text { Confidence } \\
\text { Interval of the } \\
\text { Difference }\end{array}$} & & & \\
\hline & & & & Lower & Upper & & & \\
\hline $\begin{array}{c}\text { Pair } 1 \text { posttest - } \\
\text { pretest }\end{array}$ & 10.865 & 6.215 & 1.022 & 8.793 & 12.937 & 10.635 & 36 & .000 \\
\hline
\end{tabular}

Dari tabel tersebut diperoleh informasi tentang hasil uji-t Paired Sample

Test dengan nilai rata-rata pada prates dan pascates 10,865 dengan standar deviasi $6,215$ dan sig (2-tailed $)=0,00$. Artinya, ada perbedaan yang signifikan antara nilai sebelum dan setelah mahasiswa menggunakan bahan ajar hasil pengembangan peneliti. Hal itu didasarkan pada nilai sig (2-tailed) 0,00 lebih kecil dari 0,05 (alpha value).

\section{c. Hasil Uji Statistik Deskriptif, Normalitas, dan Uji-t Tes Berbicara untuk Presentasi}

Data nilai dari tes berbicara baik nilai prates maupun pascates diolah dengan menggunakan uji deskriptif SPSS 16. Hasil uji deskriptif tersebut dapat dilihat pada tabel 21 berikut ini. 
Tabel 21

Statistik Deskriptif Nilai Tes Berbicara

\begin{tabular}{|l|r|r|r|r|r|r|}
\hline & $\mathrm{N}$ & Minimum & Maximum & Sum & Mean & $\begin{array}{c}\text { Std. } \\
\text { Deviation }\end{array}$ \\
\hline Pretest & 37 & 57 & 79 & 2483 & 67.11 & 5.557 \\
Posttest & 37 & 71 & 93 & 3008 & 81.30 & 5.953 \\
Valid N (listwise) & 37 & & & & & \\
\hline
\end{tabular}

Dari tabel di atas, diketahui nilai terendah pada prates berbicara adalah 57 dan nilai tertinggi adalah 79. Nilai rata-rata (mean) sebelum menggunakan bahan ajar 67,11 dengan standar deviasi 5,56. Di samping itu, nilai terendah pada pascates berbicara adalah 71 dan nilai tertinggi adalah 93. Dari nilai pascates tersebut diperoleh nilai rata-rata 81,3 dengan standar deviasi 5,95.

Selanjutnya data nilai berbicara diolah lagi dengan menggunakan uji normalitas. Dari hasil uji normalitas tersebut dapat dikatakan data sudah normal. Lebih lanjut dapat dilihat pada tabel 22 berikut.

Tabel 22

Uji Normalitas Nilai Tes Berbicara

One-Sample Kolmogorov-Smirnov Test

\begin{tabular}{|ll|r|r|}
\hline & & pretest & Posttest \\
\hline Normal Parameters ${ }^{\mathrm{a}}$ & Mean & 37 & 37 \\
& Std. Deviation & 67.11 & 81.30 \\
& Absolute & 5.557 & 5.953 \\
Most Extreme Differences & Positive & .212 & .129 \\
& Negative & .161 & .129 \\
& & -.212 & -.115 \\
& & 1.292 & .783 \\
Kolmogorov-Smirnov Z & & .071 & .572 \\
Asymp. Sig. (2-tailed) & & &
\end{tabular}

Dari tabel di atas, uji normalitas menunjukkan sig (2-tailed) pada prates yaitu 0,071 dan pascates 0,57. Angka-angka tersebut menunjukkan bahwa data tersebut 
dapat dikatakan normal. Hal itu didasarkan pada angka sig (2-tailed) 0,071 dan 0,57 lebih besar dari 0,05. Lebih jelasnya dapat dilihat pada kurva 5 dan 6 berikut ini.

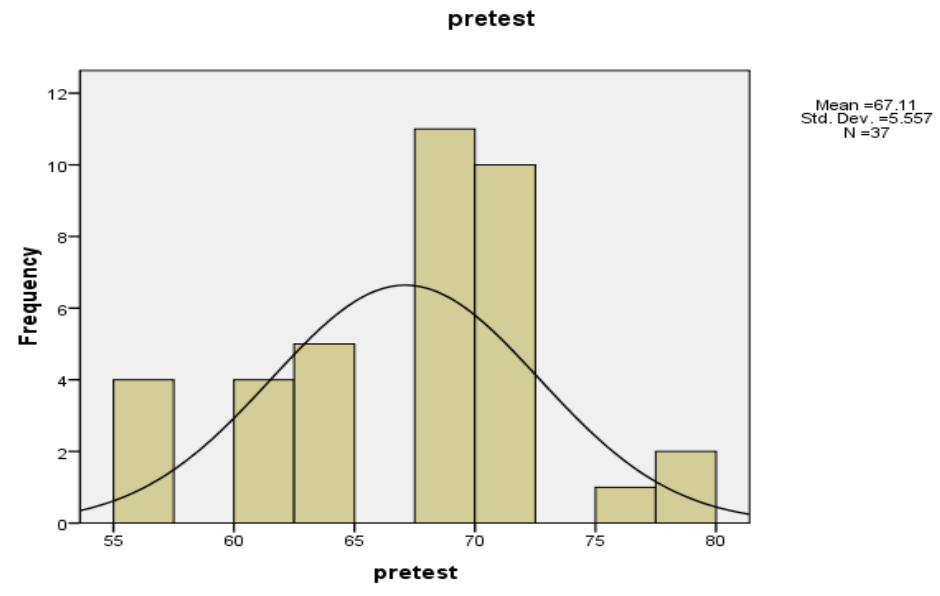

\section{Kurva 5 Kurva Uji Normalitas Nilai Prates berbicara}

Kurva 5 di atas menunjukkan sebuah histogram yang berisi distribusi nilai pada prates berbicara untuk presentasi. Melalui histogram tersebut dapat diuraikan rentang nilai mahasiswa dengan jumlah mahasiswa yang mencapainya. Contohnya rentang nilai 55-57,5 diperoleh 4 mahasiswa. Rentang nilai $60-62,5$ diperoleh 4 mahasiswa dan seterusnya. Di sisi lain, kurva yang ditunjukkan pada histogram tersebut dinyatakan normal karena berbentuk simetris.

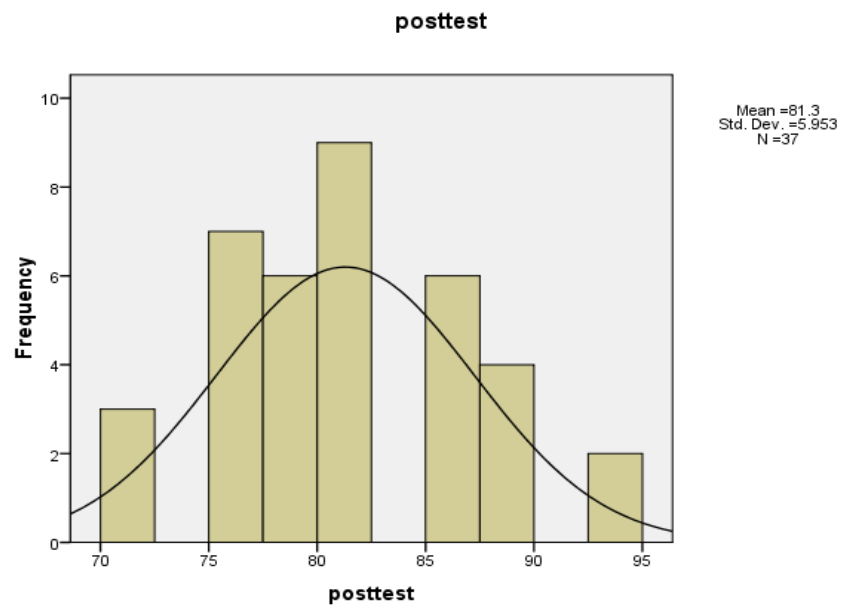

\section{Kurva 6 Uji Normalitas Nilai Pascates Berbicara}

Pada histogram tersebut, kurva pada nilai pascates berbicara untuk presentasi dikatakan normal. Hal itu disebabkan karena bentuk kurvanya yang simetris dan 
membentuk puncak (peak). Informasi lain yang dapat dideskripsikan adalah distribusi nilai pada tiap-tiap kelas intervalnya. Misalkan, rentang nilai 70—72,5 diraih oleh 3 mahasiswa sedangkan rentang nilai 75-77,5 diraih 7 mahasiswa dan seterusnya.

Data selanjutnya dianalisis untuk uji-t melalui SPSS 16. Melalui uji ini diperoleh nilai rata-rata prates dan pascates berbicara untuk presentasi 14,189 dengan standar deviasi 4,109 dengan sig (2-tailed) =0,00. Artinya, ada perbedaan yang signifikan antara nilai prates dan pascates berbicara untuk presentasi. Hal itu didasarkan pada nilai sig (2-tailed) 0,00 lebih kecil dari nilai alfa sebesar 0,05. Secara lebih jelas dapat dilihat pada tabel 23 berikut.

\section{Tabel 23}

\section{Hasil Uji-t Berbicara untuk Presentasi}

Paired Samples Test

\begin{tabular}{|c|c|c|c|c|c|c|c|c|}
\hline & \multicolumn{5}{|c|}{ Paired Differences } & \multirow[b]{3}{*}{$\mathrm{t}$} & \multirow[b]{3}{*}{ df } & \multirow{3}{*}{$\begin{array}{l}\text { Sig. (2- } \\
\text { tailed) }\end{array}$} \\
\hline & \multirow[b]{2}{*}{ Mean } & \multirow{2}{*}{$\begin{array}{c}\text { Std. } \\
\text { Deviation }\end{array}$} & \multirow{2}{*}{$\begin{array}{c}\text { Std. Error } \\
\text { Mean }\end{array}$} & \multicolumn{2}{|c|}{$\begin{array}{c}95 \% \text { Confidence } \\
\text { Interval of the } \\
\text { Difference }\end{array}$} & & & \\
\hline & & & & Lower & Upper & & & \\
\hline $\begin{array}{ll}\text { Pair } & \text { posttest } \\
1 & \text { - pretest }\end{array}$ & 14.189 & 4.109 & .675 & 12.819 & 15.559 & 21.007 & 36 & .000 \\
\hline
\end{tabular}

\section{Hasil Wawancara}

Wawancara terhadap mahasiswa setelah menggunakan bahan ajar dilakukan pada tanggal 25 Oktober 2013 dan terhadap dosen pada tanggal 26 Oktober 2013. Wawancara ini dilakukan untuk mengetahui respons dan penilaian subjek penelitian terhadap bahan ajar yang dikembangkan peneliti.

Wawancara kepada mahasiswa sebagai subjek penelitian ini dilakukan sebanyak 2 orang di Fakultas Pertanian Universitas Muhammadiyah Palembang. Wawancara ini dilakukan pada tanggal 25 Oktober 2013 setelah melakukan pascates. Berdasarkan hasil wawancara terhadap mahasiswa untuk modul Bahasa 
Indonesia untuk Perguruan Tinggi ini sudah baik tetapi ada bagian-bagian yang perlu diperbaiki.

Dari segi materi, modul Bahasa Indonesia untuk Perguruan Tinggi hasil pengembangan peneliti, sudah baik dan mudah dipahami. Hal tersebut disebabkan modul tersebut disusun secara sistematis, dengan menampilkan kajian teori secara singkat, contoh-contoh, dan langkah-langkah dalam mencapai tujuan materi tersebut. Misalkan pada kegiatan menulis paragraf, modul ini dilengkapi dengan langkah-langkah menulis paragraf secara jelas.

Hasil wawancara kepada mahasiswa dan dosen secara keseluruhan tidak jauh berbeda. Ada beberapa saran-saran yang diberikan oleh mahasiswa dan dosen terkait dengan bahan ajar ini. Dari segi bahasa, saran-saran lebih ditekankan pada penggunaan istilah dan bahasa yang umum dan mudah dipahami.

Di samping itu, tampilan fisik atau cover harus lebih menarik tetapi tetap sederhana. Mereka berpendapat bahwasanya sebuah cover harus menjadi daya tarik pertama bagi sebuah modul. Ketertarikan cenderung dimulai dari tampilan fisik sebuah produk, khususnya bahan ajar seperti modul.

Selain kepada mahasiswa, wawancara ini diberikan juga kepada 2 dosen yang mengampu matakuliah Bahasa Indonesia di Universitas Muhammadiyah Palembang. Kesimpulan dari hasil wawancara terhadap dosen ini tidak jauh berbeda dari wawancara kepada mahasiswa, bahwa modul ini sudah baik dan sangat menarik dari segi tampilan dan sajiannya.

\section{B. Pembahasan}

Langkah awal dari penelitian pengembangan ini adalah analisis kebutuhan, baik kebutuhan mahasiswa maupun dosen. Berdasarkan identifikasi awal tersebut diperoleh data tentang kesulitan dan hambatan mahasiswa dalam pembelajaran matakuliah bahasa Indonesia. Kesulitan-kesulitan tersebut tidak hanya disebabkan oleh faktor kurang menariknya materi bahasa Indonesia tetapi juga faktor ketersediaan bahan ajar. Untuk mengatasi permasalahan tersebut, mahasiswa membutuhkan bahan ajar yang lengkap, mudah dipahami, dan dari segi penyajian yang menarik. 
Bahan ajar yang dikembangkan dalam penelitian ini merupakan bentuk pengakomodasian dari berbagai harapan dan keinginan mahasiswa. Artinya, semua aspek dalam bahan ajar ini disusun sesuai dengan yang dikehendaki oleh subjek penelitian. Aspek-aspek tersebut meliputi: (1) materi, (2) sistematika penyajian, (3) topik-topik atau informasi pendukung materi, (4) bentuk latihan dan tes formatif, (5) penilaian, dan (6) cover atau tampilan fisik bahan ajar.

Secara fisik, bahan ajar yang diharapkan oleh mahasiswa adalah bahan ajar yang menarik. Artinya, bahan ajar ini dikembangkan dengan tetap memperhatikan isi materi tetapi tetap menarik minat bagi mahasiswa. Di samping tampilan cover yang harus menunjang, bagian materi dalam bahan ajar juga harus didesain menarik. Misalnya, bagian-bagian terpenting dalam bahan ajar yang menjadi bagian vital harus tersaji dengan visual yang berbeda dengan bagian lainnya.

Di samping analisis kebutuhan mahasiswa, peneliti juga menganalisis kebutuhan para dosen. Pada dasarnya, analisis kebutuhan dosen tidak jauh berbeda dengan analisis kebutuhan mahasiswa. Semua dosen menginginkan bahan ajar yang menarik, mudah dipahami, dan lengkap. Dengan adanya bahan ajar ini, diharapkan dapat menunjang dan membantu proses belajar mengajar di kelas.

Setelah analisis kebutuhan mahasiswa dan dosen, langkah berikutnya adalah menyusun dan mengembangkan bahan ajar. Bahan ajar berupa modul ini dikembangkan berdasarkan harapan-harapan mahasiswa. Bahan ajar ini dilengkapi komponen-komponen seperti: (1) petunjuk penggunaan, (2) judul, (3) tujuan, (4) materi pokok dan pendukung, (5) latihan, (6) petunjuk jawaban latihan, (7) rangkuman, (8) tes formatif, (9) kunci jawaban tes formatif, dan (10) daftar pustaka.

Bahan ajar yang sudah disusun selanjutnya divalidasi untuk mendapatkan masukan dan saran-saran dari para pakar. Validasi ini mencakup empat aspek, yaitu aspek kelayakan materi/isi, aspek penyajian, aspek kebahasaan, dan aspek kegrafikaan. Hasil validasi dari para pakar menunjukkan nilai yang bervariasi. Namun secara keseluruhan, nilai yang diperoleh dalam validasi ini adalah baik. Ada beberapa saran-saran dari para pakar yang selanjutnya dijadikan sebagai perbaikan modul. 
Modul ini memiliki beberapa kelebihan bila dibandingkan dengan bahan ajar yang lain. Pertama, modul hasil pengembangan ini berdasarkan analisis kebutuhan mahasiswa dan dosen. Artinya, modul ini berisikan materi-materi yang sesuai dengan kebutuhan peserta didik. Pada buku ajar yang lain, materi atau konten isinya banyak yang tidak didasarkan pada analisis kebutuhan sehingga peserta didik banyak yang tidak membutuhkan beberapa materi tersebut.

Kelebihan yang lain dari modul hasil pengembangan ini adalah praktis dan sistematis. Modul ini menekankan pada langkah-langkah praktis dalam mencapai tujuan pembelajaran, seperti langkah menulis pargraf, esai, makalah, dan lainnya. Pada bahan ajar yang ada sebelumnyahanya bersifat teoritis saja tanpa dilengkapi langkah-langkah konkrit sehingga menyulitkan bagi peserta didik.

Di sisi lain, modul hasil pengembangan ini disajikan beberapa contoh dan pemamparan melalui tema atau topik yang sesuai dengan jurusan peserta didik. Artinya, dengan metode seperti ini peserta didik akan lebih cepat dalam memahami materi bahasa Indonesia.

Kelebihan yang lain adalah sifat dari modul hasil pengembangan ini yang disusun agar peserta didik dapat belajar mandiri. Dengan modul ini, mahasiswa dapat belajar sesuai dengan kemampuan mereka. Bila mahasiswa belum memahami materi sebelumnya maka dapat belajar mandiri tanpa bantuan guru atau dosen sampai peserta didik memahaminya. Kepraktisan modul ini disesuaikan dengan gaya belajar peserta didik yang tidak sama antara satu dengan yang lain.

Tahap selanjutnya adalah uji coba pada 37 subjek penelitian. Uji coba ini dilakukan pada mahasiswa kelas agro A, Fakultas pertanian Universitas Muhammadiyah Palembang. Uji coba ini dibagi menjadi dua bagian, yaitu prates dan pascates. Berdasarkan hasil uji coba, diperoleh informasi adanya peningkatan kemampuan mahasiswa dalam pembelajaran bahasa Indonesia.

Indikator peningkatan kemampuan mahasiswa tersebut dapat dilihat dari nilai rata-rata sebelum dan setelah menggunakan bahan ajar. Misalnya pada tes kemampuan umum, nilai rata-rata sebelum menggunakan bahan ajar adalah 66,38, sedangkan setelah menggunakan bahan ajar adalah 81,19. Artinya, ada peningkatan 
yang cukup signifikan setelah menggunakan bahan ajar hasil pengembangan peneliti.

Pada hasil tes menulis esai, pencapaian nilai mahasiswa juga mengalami peningkatan. Pada prates, nilai rata-rata (mean) adalah 67,54, sedangkan pada pascates adalah 78,41. Dari data tersebut dapat dinyatakan ada peningkatan kemampuan mahasiswa setelah menggunakan bahan ajar hasil pengembangan. Demikian juga pada tes berbicara, ada peningkatan pencapaian nilai mahasiswa. Nilai rata-rata sebelum menggunakan bahan ajar 67,11, sedangkan setelah menggunakan bahan ajar adalah 81,3.

Berdasarkan pada perhitungan uji-t dengan menggunakan SPSS 16 diperoleh informasi bahwa bahan ajar Bahasa Indonesia untuk Perguruan Tinggi hasil pengembangan peneliti berpengaruh positif terhadap peningkatan kemampuan berbahasa mahasiswa.

Peningkatan kemampuan mahasiswa ini tidak hanya disebabkan ketersediaan bahan ajar saja, tetapi juga lebih pada isi dan penyajiannya. Isi materi dalam bahan ajar hasil pengembangan ini disusun sesuai dengan harapan mahasiswa. Artinya, pemilihan materi dan informasi pendukung disajikan sesuai harapan mahasiswa. Dalam hal penyajian, bahan ajar ini lebih mengedepankan langkah-langkah praktis dalam mencapai kompetensi yang diinginkan dan tidak bertumpu pada teori semata. Tentu saja bahan ajar hasil pengembangan ini jauh berbeda dengan buku-buku teks yang sudah ada.

Modul hasil pengembangan penelitian ini berpengaruh positif terhadap hasil belajar mahasiswa. Kecenderungan adanya pergeseran guru atau dosen yang awalnya sebagai sumber belajar satu-satunya ke arah sebagai fasilitator dan mediator menuntut kehadiran sebuah bahan ajar, khususnya modul. Modul ini mampu mengakomodasi berbagai hambatan dalam belajar, salah satunya adalah perbedaan karakteristik para peserta didik. Hal tersebut juga ditegaskan Lestari (2013:7) bahwa karakteristik siswa yang berbeda berbagai latar belakangnya akan terbantu dengan adanya bahan ajar, karena dapat dipelajari sesuai dengan kemampuan yang dimilikinya. 
Kesimpulannya, bahan ajar yang dikembangkan berdasarkan identifikasi kebutuhan akan berpengaruh pada peningkatan kemampuan berbahasa mahasiswa. Peningkatan ini dibuktikan pada hasil tes mengalami peningkatan dari nilai prates dan pascates yang selanjutnya diuji juga melalui uij-t.

\section{SIMPULAN DAN SARAN}

\section{A. Simpulan}

Dari pemaparan hasil penelitian dan pembahasan, dapat disimpulkan beberapa hal.

Pertama, mahasiswa Fakultas Pertanian Universitas Muhammadiyah membutuhkan bahan ajar yang sesuai dengan kebutuhannya. Analisis kebutuhan mahasiswa tersebut diperoleh melalui angket dan wawancara. Kebutuhan mahasiswa tersebut meliputi kebutuhan yang bersifat isi dan tampilan (cover). Bahan ajar dari segi isi, mahasiswa membutuhkan bahan ajar yang memiliki materi menarik, penyajian yang terinci, dan penggunaan bahasa yang mudah dipahami. Segi tampilan, mahasiswa mengharapkan bahan ajar yang menarik dari dan tampilan desain isi yang mampu memberikan daya tarik bagi mahasiswa.

Kedua, modul yang dikembangkan dalam penelitian pengembangan ini memiliki spesifikasi (1) penekanan pada langkah-langkah dan meminimalkan teoriteori saja, (2) penyajian contoh-contoh sebagai acuan bagi mahasiswa, (3) latihan dan tes yang bervariasi, dan (4) rubrik penilaian bagi setiap kegiatan pembelajaran.

Ketiga, modul Bahasa Indonesia untuk Perguruan Tinggi ini dapat dinyatakan layak digunakan di Fakultas Pertanian Universitas Muhammadiyah Palembang. Hal ini didasarkan pada hasil validasi yang dilakukan terhadap empat aspek, yaitu aspek materi, kebahasaan, penyajian, kegrafikaan, dan uji coba satu kelas.

Keempat, modul hasil pengembangan ini dapat meningkatkan kemampuan berbahasa mahasiswa. Pengaruh positif tersebut dapat dinilai dari nilai rata-rata sebelum dan sesudah menggunakan bahan ajar, baik tes kemampuan berbahasa umum, tes menulis esai, dan tes berbicara. 


\section{B. Saran}

Berdasarkan hasil penelitian, pembahasan, dan kesimpulan di atas, ada beberapa saran-saran yang dapat diajukan.

1) Para dosen bahasa Indonesia, khususnya dosen Muhammadiyah Palembang hendaknya dapat mengembangkan sebuah bahan ajar yang dapat digunakan untuk memudahkan dalam proses pembelajaran, khususnya pada matakuliah Bahasa Indonesia.

2) Modul yang dikembangkan ini telah diujicobakan pada tahap uji coba lapangan, yaitu pada kelas Agro A pada Fakultas Pertanian Universitas Muhammadiyah Palembang. Untuk memperoleh bahan ajar yang sesuai dengan kebutuhan secara luas, perlu dilakukan penelitian bahan ajar dengan mempertimbangkan kebutuhan mahasiswa dan dosen dari universitas lain yang memiliki karakteristik berbeda.

3) Hasil penelitian pengembangan ini dapat dilanjutkan pada penelitian pengembangan bahan ajar lain yang memiliki spesifikasi yang sama dengan penelitian ini.

\section{Daftar Pustaka}

Agustina, Aryanti. 2013. Pengembangan Modul Keterampilan Menulis I Program Studi Pendidikan Bahasa Sastra Indonesia dan Daerah Fakultas Keguruan dan Ilmu Pendidikan Universitas Baturaja. Palembang: Unsri.

Alex dan Achmad H.P. 2011. Bahasa Indonesia untuk Perguruan Tinggi. Jakarta: Kencana.

Arka, A. 2013. Rencana Pelaksanaan Pembelajaran. http://goresanilmoe.blogspot.com/2013/03/rencana-pelaksanaanpembelajaran_831.html\#ixzz2d8ezi2Kw. Diakses tanggal 18 Agustus 2013.

Depdiknas. 2008. Kamus Besar Bahasa Indonesia. Jakarta: Balai Pustaka.

Depdiknas. 2008. Panduan Pengembangan Bahan Ajar. Jakarta: Direktorat Pembinaan Sekolah Menengah Atas Dirjen Manajemen Pendidikan Dasar dan Menengah Depdiknas. 
Dick, Carey, dan O. Carey. 2005. The Systematic Design of Instruction. Boston: Pearson.

Dikti. 2006. Rambu-rambu Pelaksanaan Kelompok Matakuliah Pengembangan Kepribadian di Perguruan Tinggi. Jakarta: Direktorat Jendral Pendidikan Tinggi Departemen Pendidikan Nasional Republik Indonesia.

Finoza, Lamuddin. 2003. Komposisi Bahasa Indonesia untuk Mahasiswa Nonjurusan Bahasa. Jakarta: Diksi Insan Mulia.

Gur, Wieke. 2009. Bahasa Indonesia, Siapa yang Seharusnya Belajar? http://www.bahasakita.com/articles/bahasa-indonesia-siapa-yangseharusnya-belajar/ . Diakses tanggal 6 April 2013.

Haryadi dan Gunawan Ismail. 2010. Buku Ajar Matakuliah Bahasa Indonesia. Palembang: Universitas Muhammadiyah Palembang.

Ipriansyah. 2011. Pengembangan Modul Membaca Cerita Pendek Kelas X SMA Negeri 1 Jarai. Palembang: Unsri.

Kementerian Pendidikan Nasional RI. 2000. Pedoman Penyusunan Kurikulum Pendidikan Tinggi dan Penilaian Hasil Belajar Mahasiswa. Jakarta: Biro Hukum dan Hubungan Masyarakat Depatemen Pendidikan Nasional.

Lestari, Ika. 2013. Pengembangan Bahan Ajar Berbasis Kompetensi. Padang: Akademia.

Musaba, Zulkifli. 2012. Bahasa Indonesia untuk Mahasiswa. Yogyakarta: Aswaja.

Nunan, D. 1992. The Teacher-Centered Curriculum: A Study in Second Language Teaching.Cambridge: Cambridge University Press.

Nurhayati. 2012. Silabus: Teori dan Aplikasi Pengembangannya. Yogyakarta: Leutika Prio.

Oshima, Alice dan Ann Hogue. 1999. Writing Academic English. White Plains: Longman.

Pamungkas, Sri. 2012. Bahasa Indonesia dalam Berbagai Perspektif. Yogyakarta: Andi.

Prastowo, Andi. 2010. Panduan Kreatif Membuat Bahan Ajar Inovatif. Yogyakarta: Diva Pers.

Purwanto. 2007. Pengembangan Modul. Jakarta: Pusat Teknologi Informasi dan Komunikasi Pendidikan (PUSTEKKOM). 
Purwanto, Ngalim. 2010. Prinsip-prinsip dan Teknik Evaluasi Pengajaran. Bandung: ROSDA.

Rahayu, Minto. 2007. Bahasa Indonesia di Perguruan Tinggi: Matakuliah Pengembangan Kepribadian. Jakarta: Grasindo.

Rahim, Farida. 2008. Pengajaran Membaca di Sekolah Dasar. Jakarta: Bumi Aksara.

Setiawan, D. 2007. Pengembangan Bahan Ajar. Jakarta: Universitas Terbuka.

Setiawan, Iwan. 2009. Pengembangan Modul Pembelajaran Matakuliah Umum Bahasa Indonesia pada Fakultas hukum Universitas Wisnuwardhana Malang.

(http://karyailmiah.um.ac.id/index.php/disertasi/article/view/1876). Diakses tanggal 17 desember 2013.

Sirait, Charles Bonar. 2012. Public Speaking for Teacher. Jakarta: Grasindo.

Subadiyono. 2011. Peningkatan Pemahaman Bacaan dengan Menggunakan Pendekatan Interaktif. Yogyakarta: Pohon Cemara.

Sugiyono. 2012. Metode Penelitian Pendidikan. Bandung: Alfabeta.

Sugono, Dendi. 2009. Sumber: Suara Pembaharuan, Kamis 28 Mei 2009. Dalam http://www.bahasakita.com/news/perguruan-tinggi-jangan-kerdilkanbahasa-indonesia/ . Diakses tanggal 6 April 2013.

Sugono, Dendi. 2009. Mahir Berbahasa Indonesia dengan Benar. Jakarta: Gramedia.

Suwandi, dkk. 2007. Buku Ajar Matakuliah Pengembangan Kepribadian (MPK) Bahasa Indonesia. Palembang: Unit Pengembangan teknis MPK Universitas Sriwijaya.

Tomlinson, Brian (Ed). 1998. Materials Development in Language Teaching. Cambridge: Cambridge University Press.

Uno, Hamzah B dan Satria Koni. 2012. Assessment Pembelajaran. Jakarta: Bumi Aksara.

Wahyuni, Sri dan Abdul Syukur Ibrahim. 2012. Asesmen Pembelajaran Bahasa. Malang: Refika Aditama.

Widjono, Hs. 2005. Bahasa Indonesia Matakuliah Pengembangan Kepribadian di Perguruan Tinggi. Jakarta: Grasindo. 